UNIVERSIDADE DE SÃO PAULO

FACULDADE DE ECONOMIA, ADMINISTRAÇÃO E CONTABILIDADE DEPARTAMENTO DE CONTABILIDADE E ATUÁRIA

PROGRAMA DE PÓS-GRADUAÇÃO EM CONTROLADORIA E CONTABILIDADE

SAYURI UNOKI DE AZEVEDO

DISCLOSURE E INFLUÊNCIA SOCIAL NA CAPTAÇÃO DE RECURSOS EM ORGANIZAÇÕES SEM FINS LUCRATIVOS

SÃO PAULO

2017 
Prof. Dr. Marco Antônio Zago Reitor da Universidade de São Paulo

Prof. Dr. Adalberto Américo Fischmann

Diretor da Faculdade de Economia, Administração e Contabilidade

Prof. Dr. Ariovaldo dos Santos

Chefe do Departamento de Contabilidade e Atuária

Prof. Dr. Luiz Paulo Lopes Fávero

Coordenador do Programa de Pós-Graduação em Controladoria e Contabilidade 
SAYURI UNOKI DE AZEVEDO

\title{
DISCLOSURE E INFLUÊNCIA SOCIAL NA CAPTAÇÃO DE RECURSOS EM ORGANIZAÇÕES SEM FINS LUCRATIVOS
}

\author{
Tese apresentada ao Programa de Pós- \\ Graduação em Controladoria e Contabilidade \\ da Faculdade de Economia, Administração e \\ Contabilidade da Universidade de São Paulo \\ como requisito para obtenção do título de \\ Doutora em Ciências.
}

Orientador: Prof. Dr. Andson Braga de Aguiar

\section{SÃO PAULO}




\section{FICHA CATALOGRÁFICA}

Elaborada pela Seção de Processamento Técnico do SBD/FEA/USP

Azevedo, Sayuri Unoki de

Disclosure e influência social na captação de recursos em organizações sem fins lucrativos / Sayuri Unoki de Azevedo. - São Paulo, 2017.

$153 \mathrm{p}$.

Tese(Doutorado) - Universidade de São Paulo, 2017.

Orientador: Andson Braga de Aguiar.

1. Contabilidade de empresas não lucrativas 2. Captação de recursos

financeiros 3. Influências sociais I. Universidade de São Paulo.

Faculdade de Economia, Administração e Contabilidade. II. Título.

CDD - 658.151 
A todos que fizeram parte desta trajetória, especialmente à minha família! 



\section{AGRADECIMENTOS}

Em primeiro lugar, agradeço a Deus o dom da vida e me permitir chegar até aqui, dando-me toda a capacitação e inspiração para concluir esta tese. Agradeço a todos que oraram por mim, mesmo sem meu conhecimento, pois em momentos difíceis as orações foram primordiais para que eu me mantivesse na caminhada.

Minha sincera gratidão também ao meu esposo Rodney Dohopiati Chuver, a quem eu amo e que me apoiou em tudo, suportando-me em momentos árduos com palavras sábias que me propiciaram conselhos sábios que muito contribuíram para me concentrar no que era importante, bem como à minha eterna amada mãe, Akiko Alice Unoki, que não poupou esforços para me ver bem e me ajudar.

Aos meus familiares, muito obrigada! À minha tia Verônica de Azevedo Mazza, agradeço as suas palavras e ações de incentivo, ao meu avô, Ary Guimarães de Azevedo, o seu apoio sempre, e ao meu pai, Fábio Melo de Azevedo, o tempo juntos e as palavras encorajadoras.

Sou imensamente grata ao meu orientador, Prof. Dr. Andson Braga de Aguiar, por todos os seus ensinamentos. Por não poupar esforços e tempo para me conduzir durante todo o doutorado, incentivando-me a prosseguir e aperfeiçoar minha tese. Um verdadeiro orientador, com muita paciência, sempre com conselhos sábios e bons direcionamentos.

Meu agradecimento a todos os professores do Departamento de Contabilidade e Atuária da FEA/USP pelos ensinamentos e conhecimentos. Em especial ao Prof. Fábio Frezatti, pelo apoio em tudo, pelo incentivo, pelo conhecimento transmitido e exemplo de competência e dedicação.

Agradeço também às professores que compuseram a banca de qualificação e de defesa, Prof. ${ }^{a}$ Dr. ${ }^{\text {a }}$ Patrícia Siqueira Varela, Prof. ${ }^{a}$ Dr. ${ }^{\text {a }}$ Simone Bernardes Voese, Prof. ${ }^{\text {a }}$ Dr. ${ }^{\text {a }}$ Ana Maria Roux Valentini Coelho Cesar, Prof. Dr. Fernando Dal-Ri Murcia e Prof. Dr. Marcus Vinícius Moreira Zittei, seus pertinentes apontamentos e as contribuições que engrandeceram este estudo e, ao Prof. Frank Hartmann, o conhecimento compartilhado durante o II USP Doctoral Consortium on Quantitative Research in Accounting. Também a todos os colegas que estiveram presentes e me propuseram as suas contribuições.

Agradeço a todos os colegas que fiz, do mestrado e do doutorado do PPGCC FEA/USP, e que permitiram que a trajetória fosse mais alegre e fácil. Sobretudo, um obrigado especial para a Raquel e o Alex, que me apoiaram e me ajudaram a encontrar um local para morar; ao Cláudio, ao Sérgio e ao Christopher, amigos com quem pude conviver durante 
minha estada em São Paulo; à Verônica, à Bianca e à Cíntia, que me apoiaram no que precisei e me receberam sempre muito bem. Também agradeço à Diane, Talles, Sandro, Cristiane, Eduardo Flores, Fábio, Eduardo Martinez, Ademir, Patrícia, Sara, a boa convivência.

Agradeço aos professores do Departamento de Contabilidade da UFPR que entenderam minha necessidade de tempo para concluir o doutorado, principalmente ao Prof. Jackson Ciro Sandrini, seu apoio e direcionamento. Agradeço de forma especial aos colegas, Prof. Henrique Portulhak e Prof. Flaviano Costa, toda ajuda, conhecimento e contribuições, e o convívio na UFPR. Agradeço também aos professores Blênio Cezar Severo Peixe, Luiz Carlos Souza, Jackson Ciro Sandrino, Lauro Brito de Almeida, Luciano Márcio Scherer, Mayla Cristina Costa, Jaqueline Veneroso Alves da Cunha e Odirlei Acir Tedesco, que me propiciaram condições para que os dados desta tese fossem coletados.

Agradeço também, em especial, à minha amada amiga Juliana Miara da Cruz por estar sempre ao meu lado durante o doutorado, ao Prof. Cláudio Marcelo Edwards Barros, o auxílio e conhecimento da parte estatística e à grande amiga Prof. Joyce Menezes da Fonseca Tonin, toda ajuda e conhecimento, pois sem esse apoio com certeza a análise multivariada dos dados seria mais difícil.

Agradeço ainda, aos funcionários da FEA a cordialidade e ajuda sempre, à AFECE, a parceria no estudo, aos colaboradores as validações e pré-teste; aos respondentes que participam do estudo; e a CAPES, o apoio financeiro. 
"Estou plenamente certo de que aquele que começou boa obra em vós há de completá-la até ao Dia de Cristo Jesus."

(Filipenses 1:6) 



\section{RESUMO}

Azevedo, S. U. (2017). Disclosure e influência social na captação de recursos em organizações sem fins lucrativos. Tese de doutorado, Faculdade de Economia, Administração e Contabilidade, Universidade de São Paulo, São Paulo.

O presente estudo investiga qual o efeito que a divulgação de empresas solidárias apoiadoras e da remuneração de dirigentes de Organizações Sem Fins Lucrativos (OSFL) possui na decisão sobre o volume de contribuição e na propensão de doar futuramente por parte do doador individual. O estudo é consubstanciado em pesquisas desenvolvidas por Balsam e Harris (2014) e de Galle e Walker (2013) que encontraram evidências de que doadores reduzem as contribuições subsequente à divulgação, por parte da OSFL, de alta remuneração do dirigente; e, em pesquisa desenvolvida no Brasil por IDIS e Gallup (2016), que relatam a falta de confiança como um dos principais motivos para que doadores deixem de contribuir para as OSFL. Este estudo pressupõe que, divulgar empresas solidárias apoiadoras da OSFL gera compliance, um dos principais elementos de influência social citado por Cialdini e Trost (1998) sobre o doador, levando-o a perceber a OSFL como monitorada e, com maior confiança de que a organização cumpre a missão social para a qual se destina, reduzindo o efeito adverso ocasionado da divulgação pela própria OSFL de valores elevados de remuneração do dirigente. $\mathrm{O}$ procedimento metodológico para coleta de dados ocorreu por meio de um experimento, com 140 participantes estudantes de pós-graduação lato sensu em Ciências Contábeis da Universidade Federal do Paraná. Encontraram-se evidências de que o disclosure voluntário pela OSFL de empresa solidária apoiadora possui efeito positivo significativo na propensão de contribuição futura do doador individual, assim como o disclosure da remuneração do dirigente e da empresa solidária apoiadora, de forma interativa, conduz à maior probabilidade de doação futura pelo doador individual. Esperava-se que a divulgação da empresa solidária apoiadora apenas, ou essa em conjunto com a informação de menor remuneração do dirigente gerassem maiores volumes de contribuições pelo doador, contudo, não foram obtidas evidências empíricas que suportem as referidas hipóteses. Os achados também não confirmaram a hipótese de que, divulgados maiores valores da remuneração do dirigente seriam reduzidos o volume de contribuição e a propensão de doação futura. Os resultados implicam que a divulgação da empresa solidária apoiadora pela OSFL suscita uma resposta por parte do doador em relação à probabilidade de doar futuramente em consonância à comunicação explícita da organização, neste caso a solicitação de doação, possivelmente ocorrendo o compliance como forma de influência social de direcionamento pela figura de autoridade legítima exercida pela empresa solidária apoiadora. Isto ocorre inclusive quando a divulgação é realizada em conjunto com a remuneração do dirigente, indicando a relevância do disclosure voluntário por parte das OSFL na captação de recursos. Desta forma, este estudo amplia os conhecimentos sobre o disclosure voluntário em OSFL, principalmente relacionado à divulgação da empresa solidária apoiadora como fonte de autoridade legítima e do efeito de compliance sobre o doador individual.

Palavras-chave: Organizações sem fins lucrativos, Disclosure voluntário, Influência social, Compliance, Remuneração do dirigente, Empresa solidária apoiadora. 


\begin{abstract}
Azevedo, S. U. Disclosure and social influence in fundraising in non-profit organizations. Doctoral thesis, College of Economics, Administration and Accounting, University of Sao Paulo, Sao Paulo.

This study investigates the effect of disclosure of Influential Institutional Partners and senior management's compensation on individuals' decisions to donate for non-profit organizations (NPOs). Prior research (Balsam \& Harris, 2014; Galle \& Walker, 2013) indicate that donors reduce donations after the disclosure of senior manager's high compensation by the NPOs, and in the Brazilian setting (IDIS \& Gallup, 2016), lack of trust is one of the main reported reasons for donors to stop contributions for NPOs. Based on the literature on social influence, this study argues that the Influential Institutional Partner's disclosure increases the donors' compliance with the NPOs (Cialdini \& Trost, 1998). This behaviour should lead donors to conclude that the NPO is an entity under monitoring, and drive higher trust that the organization reaches the social mission for which it is intended, reducing the adverse effect caused by the disclosure of senior management's high compensation. The experimental is conducted with 140 graduate accounting students at the Federal University of Parana (UFPR). The results indicate that NPOs voluntary disclosure has a significant positive effect on the individual donors' propensity of future donations, as does, interactively, the disclosure of senior management' compensation and of the Influential Institutional Partners. However, no empirical evidence was found supporting the main or interactive effects of disclosure of Influential Institutional Partners and senior management's compensation on donors contribution's amount. Findings also did not confirm that disclosure of senior management's higher compensation result in lower propensity of future donations by individual donors. The results imply that the Influential Institutional Partner's disclosure by NPOs drives a response from donors with respect to the probability of making future donations in accordance with explicit communications by the organization, leading to the compliance as a form of social influence, exerted by the legitimate authority figure represented by the Influential Institutional Partner. This also happen when the disclosure is made in conjunction with senior management's compensation, indicating the relevance of the NPO's voluntary disclosure in fundraising. This study broadens the knowledge on voluntary disclosure by NPOs, in particular about the Influential Institutional Partner' disclosure as a source of legitimate authority, and the effect of compliance on individual donors.
\end{abstract}

Keywords: Non-profit organizations, Voluntary disclosure, Social influence, Compliance, Senior management's compensation, Influential Institutional Partner. 


\section{LISTA DE FIGURAS}

Figura 1 - Caracterização das OSFL no Brasil ...................................................................... 36

Figura 2 - Estrutura de validação preditiva do experimento ............................................... 71

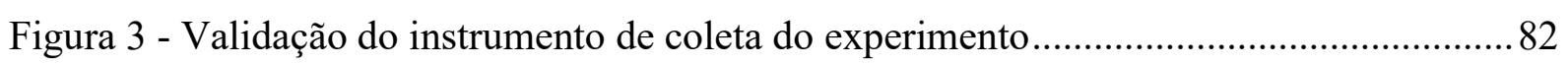





\section{LISTA DE QUADROS}

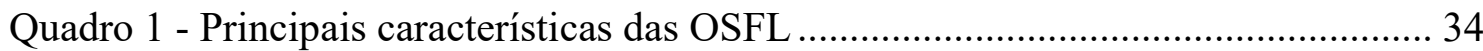

Quadro 2 - Incentivos fiscais federais concedidos a Pessoas Jurídicas.......................... 41

Quadro 3 - Incentivos fiscais federais concedidos a Pessoas Físicas ............................ 42

Quadro 4 - Referências das variáveis de controle ......................................................... 72

Quadro 5 - Matriz das condições de controle e experimentais...................................... 74

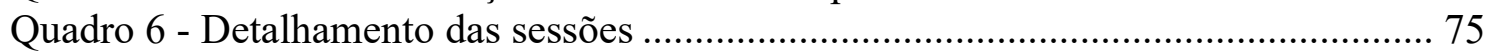

Quadro 7 - Agrupamento de "grupo de divulgação" .................................................. 83

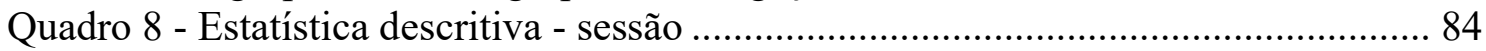

Quadro 9 - Estatística descritiva da probabilidade de doar futuramente para a AFECE 85

Quadro 10 - Estatística descritiva da avaliação da remuneração do dirigente ............... 86

Quadro 11 - Estatística descritiva dos fatores que mais motivaram a decisão ................ 86

Quadro 12 - Estatística descritiva questão Confiança................................................... 87

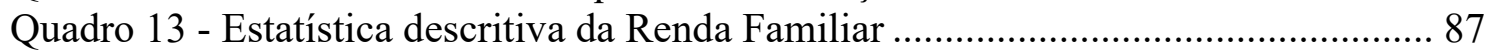

Quadro 14 - Frequências de "SIM" - Tipo de OSFL que faz doações ........................... 88

Quadro 15 - Frequências de "NÃO" - Tipo de OSFL que faz doações........................... 88

Quadro 16 - Manipulation Check - Remuneração X Percepção da Remuneração......... 89

Quadro 17 - Reclassificação de "grupo de divulgação" - efeito da remuneração.......... 91

Quadro 18 - Médias por grupo de remuneração do dirigente - KW ............................. 91

Quadro 19 - Efeito da remuneração - Qui-quadrado - frequências - Probabilidade de

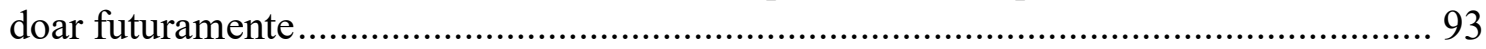

Quadro 20 - Análises adicionais - Efeito da remuneração x Variáveis Controle x Valor

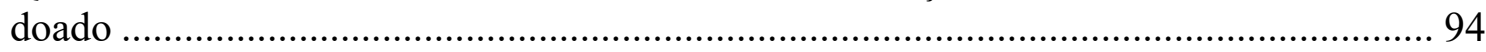

Quadro 21 - Análises adicionais - Efeito da Remuneração x Variável "escolaridade" x

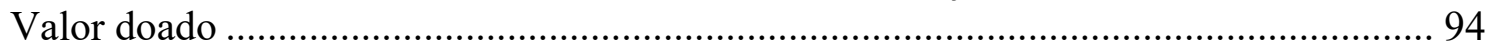

Quadro 22 - Análises adicionais - Efeito da Remuneração x Renda Familiar x

Probabilidade de doar futuramente ........................................................................... 94

Quadro 23 - Reclassificação de "grupo de divulgação" - efeito da divulgação da

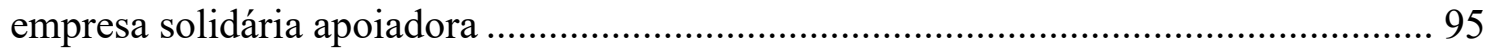

Quadro 24 - Médias por grupo - divulgadora de empresa solidária apoiadora - KW ... 95 Quadro 25 - Efeito da divulgação - Qui-quadrado frequências - Probabilidade de doar

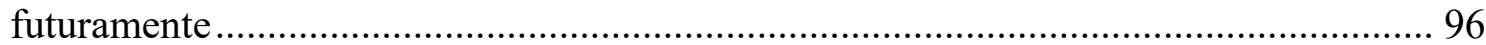

Quadro 26 - Análises adicionais - Efeito da divulgação x Variáveis Controle x Valor

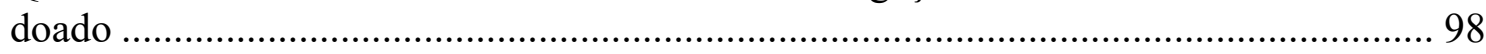

Quadro 27 - Análises adicionais - Efeito da Divulgação x Variável "escolaridade" x

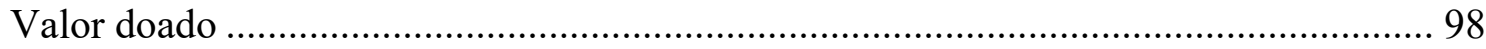

Quadro 28 - Reclassificação de "grupo de divulgação" - efeito interativo da divulgação empresa solidária apoiadora e da remuneração do dirigente ........................................ 98

Quadro 29 - Médias por grupo - interação - divulgadora de empresa solidária apoiadora

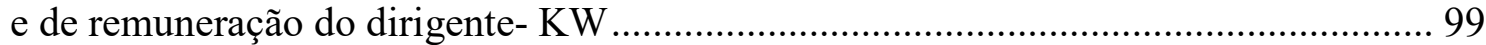

Quadro 30 - Efeito interativo da divulgação de empresa solidária apoiadora e de remuneração do dirigente - Qui-quadrado frequências - Probabilidade de doar

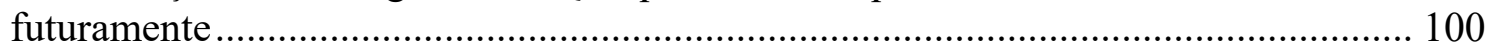

Quadro 31 - Análises adicionais - Efeito da interação x Variáveis Controle x Valor

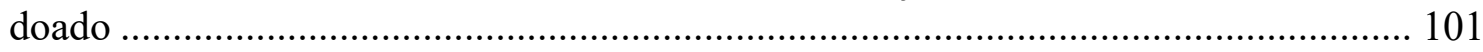

Quadro 32 - Análises adicionais - Efeito da Interação x Doação Laica x Probabilidade de doar futuramente 
Quadro 33 - Análise adicional - Remuneração do dirigente x Valor doado - KW (não

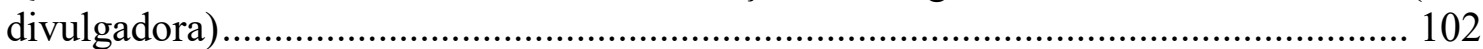

Quadro 34 - Matriz de comparações necessárias - Remuneração do dirigente x Valor doado - MW (não divulgadora)............................................................................ 102

Quadro 35 - Matriz de comparações necessárias - Empresa solidária apoiadora x Valor

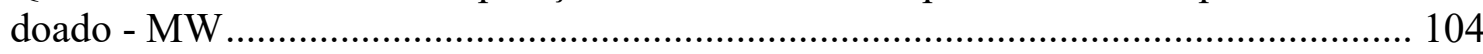

Quadro 36 - Análise adicional - médias MW - Remuneração do dirigente x Valor doado

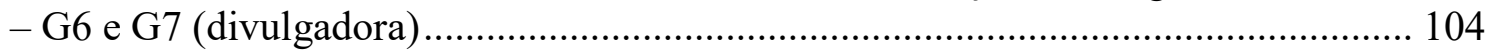

Quadro 37 - Agrupamento das Variáveis Moderadoras e da Remuneração ................. 106

Quadro 38 - Agrupamento das Variáveis Moderadoras e da Divulgação da Empresa

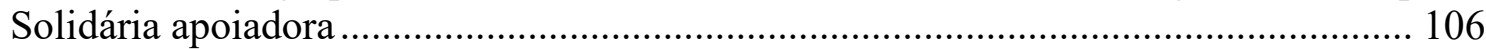

Quadro 39 - Efeito da moderação das variáveis de confiança na relação entre Remuneração e Valor doado............................................................................... 107

Quadro 40 - Efeito da moderação das variáveis de Confiança na relação entre Divulgação de Empresa Solidária apoiadora e Valor doado ........................................ 108

Quadro 41 - Relação: Menor Confiança e Remuneração alta X Maior Confiança e

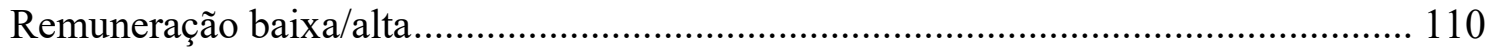

Quadro 42 - "Confiança causa" e "AFECE é confiável” na relação entre Divulgação da empresa solidária apoiadora e Probabilidade de doar futuramente (frequências) 


\section{LISTA DE ABREVIATURAS E SIGLAS}

\begin{tabular}{|c|c|}
\hline AFECE & Associação Franciscana de Educação ao Cidadão Especial \\
\hline AIP & American Institute of Philanthropy \\
\hline BBB & Better Business Bureau \\
\hline CEBAS & Certificado de Entidade Beneficente de Assistência Social \\
\hline CEMPRE & Cadastro Central de Empresas \\
\hline $\mathrm{CFC}$ & Conselho Federal de Contabilidade \\
\hline CNAS & Cadastro Nacional de Assistência Social \\
\hline CNES & Cadastro Nacional de Entidades Sociais \\
\hline COFINS & Contribuição para Financiamento da Seguridade Social \\
\hline $\mathrm{CPC}$ & Comitê de Pronunciamentos Contábeis \\
\hline CSLL & Contribuição Social sobre o Lucro Líquido \\
\hline DSDE & Demonstração do Superávit ou Déficit do Exercício \\
\hline EUA & Estados Unidos da América \\
\hline IBGE & Instituto Brasileiro de Geografia e Estatística \\
\hline ICMS & Imposto sobre a Circulação de Mercadorias e Serviços \\
\hline IDB & Índice de Disclosure Brasileiro \\
\hline IE & Imposto de Exportação \\
\hline II & Imposto de Importação \\
\hline IPI & Imposto sobre Produtos Industrializados \\
\hline IPTU & Imposto sobre Propriedade Territorial Urbana \\
\hline IPVA & Imposto sobre Propriedade de Veículos Automotores \\
\hline IR & Imposto de Renda \\
\hline IRS & Internal Revenue Service \\
\hline ISS & Imposto Sobre Serviços de qualquer natureza \\
\hline ITBI & Imposto sobre Transmissão intervivos de Bens Imóveis \\
\hline ITCD & Imposto sobre Transmissão causa mortis ou doação de bens e direitos \\
\hline ITR & Imposto Territorial Rural \\
\hline KMO & Kaiser-Meyer-Olkyn \\
\hline KS & Kolmogorov Smirnov \\
\hline KW & Kruskal Wallis \\
\hline MDS & Ministério de Desenvolvimento Social \\
\hline MEC & Ministério da Educação e Cultura \\
\hline MJ & Ministério da Justiça \\
\hline MS & Ministério da Saúde \\
\hline MW & Mann Whitney \\
\hline NBC-T & Normas Brasileiras de Contabilidade Técnicas \\
\hline ONU & Organização das Nações Unidas \\
\hline OS & Organização Social \\
\hline OSCIP & Organização da Sociedade Civil de Interesse Público \\
\hline OSFL & Organização(ões) Sem Fins Lucrativos \\
\hline RAT & Risco de Acidente do Trabalho \\
\hline RF & Receita Federal \\
\hline SEC & Securities and Exchange Commission \\
\hline SFAS & Statement of Financial Accounting Standards \\
\hline TCLE & Termo de Consentimento Livre e Esclarecido \\
\hline UFPR & Universidade Federal do Paraná \\
\hline UPF & Utilidade Pública Federal \\
\hline
\end{tabular}





\section{SUMÁRIO}

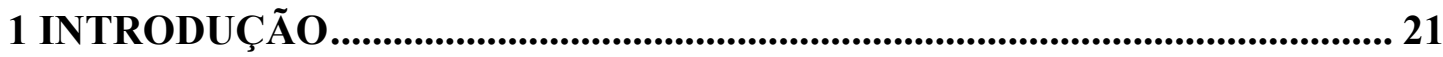

1.1 Contextualização e apresentação do tema ………………………………….... 21

1.2 Problema e objetivo da pesquisa ........................................................................ 25

1.3 Justificativa da pesquisa e contribuições do estudo.............................................. 29

1.4 Estrutura da pesquisa.................................................................................................. 33

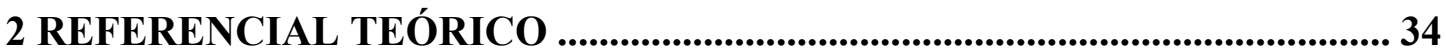

2.1 Organizações sem fins lucrativos (OSFL) …………............................................. 34

2.2 Disclosure Contábil .................................................................................................. 47

2.2.1 Literatura do disclosure de informações contábeis ....................................... 47

2.2.2 Disclosure Contábil em OSFL ....................................................................... 51

2.2.3 Disclosure de remuneração de dirigentes em OSFL ....................................59

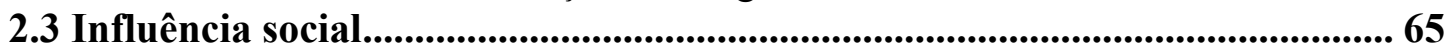

2.4 Disclosure interativo de remuneração do dirigente e da empresa solidária apoiadora em OSFL .............................................................................................................. 69

3 METODOLOGIA...................................................................................................... 71

3.1 Variáveis da pesquisa ................................................................................................ 71

3.2 Planejamento da pesquisa ............................................................................................. 73

3.3 Delineamento do experimento .................................................................................... 73

3.2.1 Tarefa experimental ................................................................................. 73

3.2.1.1 Delineamento do modelo experimental ................................................... 74

3.3 Aleatorização do experimento ………………………….......................................... 75

3.4 Procedimentos experimentais ..................................................................... 75

3.4.1 Aplicação do experimento......................................................................... 76

3.5 População e amostra .................................................................................. 79

3.6 OSFL parceira.......................................................................................................... 80

3.6.1 Empresa solidária apoiadora da OSFL parceira (AFECE) ………………... 80

3.7 Pré-teste do questionário utilizado no experimento ............................................. 81

3.8 Tratamento estatístico para análise dos dados...................................................... 82

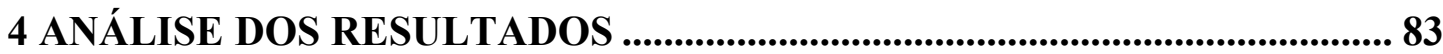

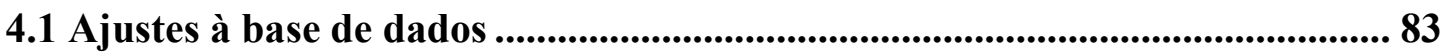

4.2 Estatística descritiva dos dados ................................................................................ 84

4.3 Análise de manipulation check ................................................................................... 89

4.4 Análises das variáveis de controle ....................................................................... 89

4.5 Análise das hipóteses da pesquisa.............................................................................90

4.5.1 Análise do efeito principal da remuneração ................................................. 90

4.5.1.1 Análise de relações das variáveis de controle (covariáveis) considerando o efeito da divulgação da remuneração ................................................................... 93

4.5.2 Análise do efeito principal da empresa solidária apoiadora.......................... 95

4.5.2.1 Análise de relações das variáveis de controle (covariáveis) considerando o efeito da divulgação da empresa solidária apoiadora............................................... 97

4.5.3 Análise do efeito interativo entre divulgação de remuneração e empresa

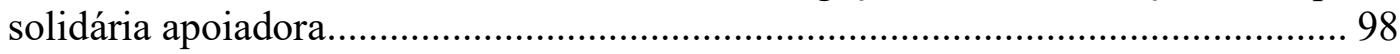


4.5.3.1 Análise de relações das variáveis de controle (covariáveis) considerando o efeito interativo entre a divulgação da remuneração e da empresa solidária

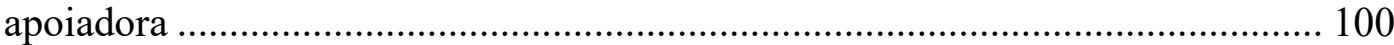

4.6 Análises adicionais - Comparação entre condições experimentais .......... 101

4.7 Análises adicionais: análise das variáveis moderadoras .......................... 106

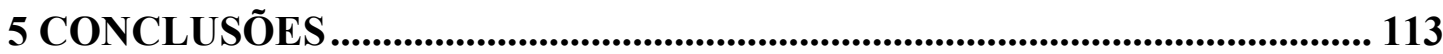

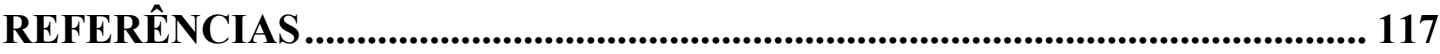

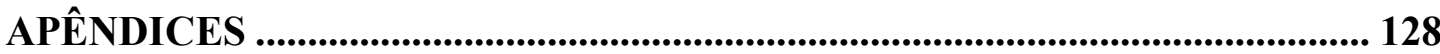

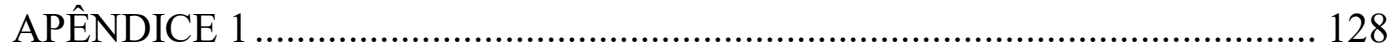

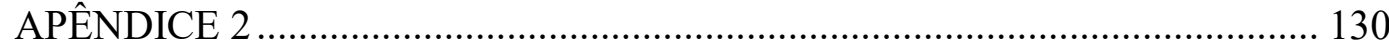

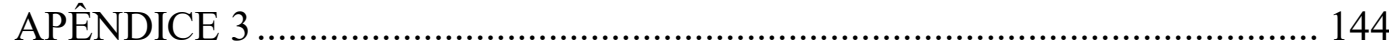

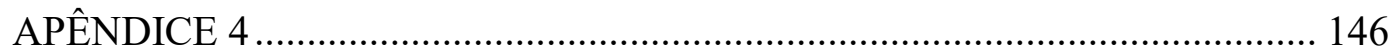

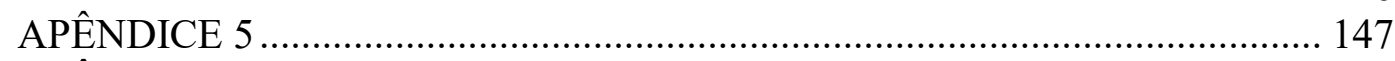

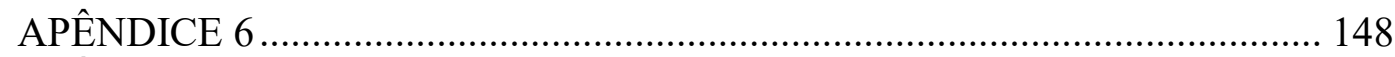

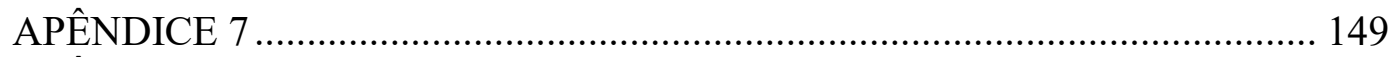

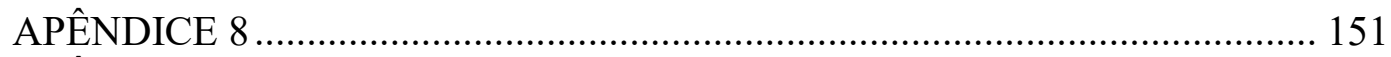

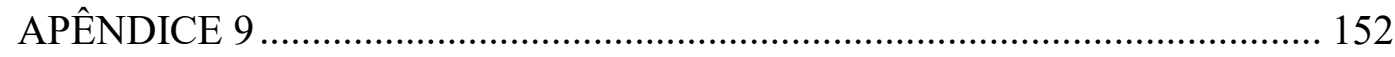




\section{INTRODUÇÃO}

\subsection{Contextualização e apresentação do tema}

As Organizações sem Fins Lucrativos (OSFL) estão ocupando gradativamente maior destaque nas sociedades contemporâneas devido à importância das atividades que realizam. Embora pessoas jurídicas de direito privado, não têm finalidade de lucro e colaboram de maneira direta com o Estado, assumem inúmeras tarefas com objetivos sociais, filantrópicos, culturais, recreativos, religiosos, artísticos, podendo atuar em parceria ou, até mesmo, substituindo o Estado na geração de alguns serviços de caráter público (Cruz \& Estraviz, 2003).

As OSFL são descritas como: (1) formais (institucionalizadas); (2) privadas; (3) não distribuidoras de lucros; (4) autônomas; (5) voluntárias; e (6) ter fins públicos (IBGE, 2010). Mais de 1,4 milhão de OSFL contribuem para 5,4\% do Produto Interno Bruto (PIB) dos Estados Unidos (EUA) e emprega 8,3\% da força de trabalho remunerada (Mckeever \& Pettijohn, 2014).

No Brasil, Silva (2010) relata que, nos anos de 1980, havia 44 mil organizações em atuação. Este número, em 2010, ultrapassa 550 mil organizações (IBGE, 2010). Comparandose aos Estados Unidos, no Brasil as OSFL movimentam cerca de 12 bilhões de reais por ano, o equivalente a 1,2\% do PIB brasileiro (Brito \& Cardoso, 2010).

Economicamente, as OSFL são caracterizadas de duas formas principais: pela variedade de receita que arrecadam e pela maneira que são controladas. Assim, quanto à primeira característica, classificam-se em Donativas (quando recebem porção substancial da receita de doações, dependendo dos doadores) e Comerciais (quando geram receita primariamente ou exclusivamente de venda de bens ou serviços, dependendo dos consumidores). Em relação à maneira que são controladas, as OSFL compreendem as Mútuas (quando doadores ou consumidores - patronos - possuem o controle para eleger os dirigentes) e as Empreendedoras (quando os dirigentes não são eleitos pelos patronos ou quando o quadro de dirigentes é autoperpetuador) (Hansmann, 1987a). Este estudo tem como foco as OSFL caracterizadas em Donativas e Empreendedoras. Para essas organizações, os doadores constituem-se stakeholders que possuem poder de decisão para qual OSFL farão sua contribuição e quanto irão contribuir. 
Direciona-se esta pesquisa para os doadores individuais (pessoas físicas). Conforme Fama e Jensen (1983) e Hansmann (1987a), doador individual é aquele que não se configura como Pessoa Jurídica e, apesar de estar no papel de stakeholder da OSFL, não possui autonomia para restringir o uso do recurso doado pela instituição e não é beneficiário dos serviços prestados. Além disso, principalmente para esta classe, não é fácil determinar se a doação está sendo direcionada inteiramente para o propósito para o qual foi feita, pois segundo Glaeser (2007) existe assimetria de informação na relação de agência entre os doadores/investidores (principais) e os dirigentes das entidades do terceiro setor (agentes).

As OSFL devem estar capacitadas para desenvolver suas atividades e demonstrar resultados que possam inspirar parcerias e auxiliem a captação de recursos (Ciconello \& Moraes, 2014). As OSFL precisam, portanto, manter relações de confiança com os seus stakeholders e, o cenário em que estão inseridas essas organizações perfaz a relevância da manutenção da sustentabilidade dos empreendimentos de caráter social desenvolvidas. Além disso, as relações entre a organização e seus stakeholders constitui uma tarefa que deve ser construída com base em reputação e legitimidade (Cruz \& Estraviz, 2003).

Os termos reputação e legitimidade surgiram como um conceito importante para explicar a atração de doações para estas organizações e constituem alguns dos ativos intangíveis mais relevantes para uma OSFL (Padanyi \& Gainer, 2003; Meijer, 2009; Sarstedt \& Schloderer, 2010). O cumprimento da missão e responder às demandas individuais e da comunidade são essenciais para este propósito (Mcdougle, 2014; Cruz \& Estraviz, 2003; Oster, 1998). Constitui-se um ciclo em que a OSFL se esforça para obter um bom desempenho com suas atividades, que permita a construção de confiança e, por sua vez, alicerce stakeholders para perpetuar os projetos da organização. Com isso, maior volume de doação assegura que a organização busque melhorar ainda mais seu desempenho.

A decisão de doar envolve a aplicação dos recursos para um propósito específico e a expectativa de que estes não sejam usados simplesmente para financiar bens privados. Consequentemente, o doador pode ter dificuldade em acompanhar o uso da sua doação e sentir a necessidade de alguma forma de feedback institucional como proteção provida pela OSFL.

Um facilitador para fortalecer a reputação de OSFL é a restrição de não distribuição, ou seja, legalmente as OSFL, caso tenham excedente de resultado, não podem distribuir aos dirigentes. Estas devem reinvestir o superávit obtido no objeto da organização (Speckbacher, 2012). 
Somente a restrição de não distribuição pode não ser suficiente para gerar a decisão do doador em favor da OSFL (Hansmann, 1987a). De modo geral, o desempenho organizacional em OSFL não está apenas relacionado à captação, mas também com a administração e utilização dos recursos. Neste sentido, é relevante que as OSFL divulguem informações para suprir essas necessidades dos doadores (Balsam \& Harris, 2014).

$\mathrm{O}$ disclosure de informações relevantes cumpre função relevante para reduzir a assimetria informacional e os problemas de agência, que impedem a alocação eficiente de recursos, em uma economia de mercado de capitais. A divulgação corporativa é, portanto, fundamental para o funcionamento deste mercado de forma eficiente (Healy \& Palepu, 2001).

Há também evidências de que os investidores visualizam divulgações voluntárias, tais como previsões de gestão, como um comunicado credível. A investigação sobre a divulgação voluntária enfoca o papel de informações dos relatórios financeiros para os mercados de capitais (Healy \& Palepu, 1993, 1995). A literatura contábil também trata das divulgações sobre as empresas por intermediários de notícias, como os analistas financeiros e agências de rating, que participam na produção de informações privadas para descobrir qualquer uso indevido de recursos pelo gerente da empresa (Healy \& Palepu, 2001).

Em OSFL, a conscientização destas e da sociedade em geral sobre a importância da transparência na gestão é primordial ao funcionamento e à manutenção de doações. $\mathrm{O}$ disclosure de informações realizadas por OSFL, seja de caráter compulsório ou as voluntárias, tem como finalidade apresentar aos stakeholders que a organização cumpre a missão para a qual foi criada e que os recursos confiados a ela foram destinados para o bem público ou para a causa para qual a organização trabalha (Carneiro, Oliveira, \& Torres, 2011; Cunha \& Matias-Pereira, 2012; Olak \& Nascimento, 2010).

O foco do disclosure, tanto das informações financeiras como das não financeiras por parte da OSFL consiste no direcionador para o desenvolvimento da accountability da organização e reforça a responsabilização da mesma, permitindo maior acuracidade e fidelidade dos dados sobre desempenho (Reiser, 2005).

De forma geral, espera-se uma relação positiva entre a prática de prestação de contas feitas por OSFL e a resposta dos doadores (Mañas \& Medeiros, 2012). Além disso, evidências empíricas demonstram que doadores externos consideram tanto informações de desempenho organizacional, quanto as de aplicação dos recursos recebidos pela instituição, incluindo a remuneração do dirigente. 
Sobre a remuneração do dirigente, estudos tratam da relação entre a divulgação desta por parte da OSFL com o volume contribuído por doadores (Andreoni, 1990; Balsam \& Harris, 2014; Galle \& Walker, 2013; Speckbacher, 2012). Pesquisadores encontraram evidências de que níveis elevados de remuneração podem levar à percepção de apropriação privada de fundos em detrimento das causas sociais (Balsam \& Harris, 2014; Galle \& Walker, 2013; Oster, 1998). Assim, o cuidado na determinação da remuneração do dirigente também perpassa pela preocupação de manutenção e atração de potenciais doadores para a OSFL.

Nos Estados Unidos, em estudo desenvolvido por Balsam e Harris (2014), os autores encontraram evidências significativas de que apoiadores reduzem doações para OSFL subsequente ao disclosure de alta compensação do executivo. Este achado também é condizente com o de Galle e Walker (2013) que preveem que os níveis de remuneração mais elevados serão associados com níveis reduzidos de contribuições.

No Brasil, em pesquisa desenvolvida em 2015, pelo Instituto para o Desenvolvimento do Investimento Social (IDIS) em parceria com o Instituto Gallup, encontrou evidências de que, entre as principais razões para não doar, foi a falta de confiança na OSFL. Adicionalmente, não doadores relatam que uma mudança de postura ocorreria se a organização demonstrasse mais transparência, prestando contas e mostrando como aplica os recursos recebidos (IDIS \& Gallup, 2015).

Pode-se dizer que existe um trade-off entre remunerar apropriadamente o dirigente e manter a reputação da OSFL frente aos doadores, diante do desafio de preservação da instituição (Hipólito, 2004). As OSFL necessitam de dirigentes capacitados, com talentos que possam contribuir para um desempenho elevado (Schloderer, Sarstedt, \& Ringle, 2014), visto o papel estratégico dos mesmos no direcionamento das atividades da organização, adicionado à expectativa dos doadores na atuação da OSFL de forma eficiente e eficaz (Handy et al., 2010; Tinkelman \& Donabedian, 2007). A não remuneração ou a remuneração aquém da base de subsistência do profissional pode fazer com que este tenha que complementar seu sustento por meio de outra fonte de trabalho, não se dedicando integralmente às atividades da organização (Grasse, Davis, \& Ihrke, 2014). Além disso, limita a competição por talento do dirigente com outras organizações (Balsam \& Harris, 2014).

A remuneração de dirigentes de OSFL, portanto, é importante para a atração de profissionais qualificados e consequentemente, reflete no desempenho organizacional. Os doadores, por sua vez, preocupam-se com a execução eficaz das atividades que a organização desenvolve e as doações constituem uma das principais fontes de manutenção das atividades das OSFL, influenciando também no rendimento destas. Assim, uma das preocupações 
existentes para uma OSFL é como sinalizar, aos atuais e potenciais doadores, que a organização desenvolve suas atividades de forma eficiente e eficaz, ou seja, possui bom desempenho sem que haja remuneração excessiva dos dirigentes.

Nos Estados Unidos a divulgação de informações de desempenho de OSFL é mais desenvolvida, havendo a publicação das mesmas com objetivo de permitir maior transparência dos dados organizacionais por meio do formulário Internal Revenue Service (IRS) Form990, disponível publicamente e que contempla a divulgação obrigatória do valor da remuneração do dirigente e como esta é determinada (Balsam \& Harris, 2014).

No Brasil, as organizações podem divulgar o Relatório de Atividades, porém não existe um padrão de informações exigidas para o mesmo. Também há a divulgação do Balanço Patrimonial e do Balanço Social, com informações sobre as políticas de atuação da organização, porém, este último não constitui um instrumento de publicação obrigatória para OSFL e não existe um modelo padrão de divulgação (Rengel, Cunha, Klann, \& Scarpin, 2012). Isso faz com que os doadores tenham maior dificuldade de observação da prestação de contas e das políticas adotadas pelas OSFL.

Comparando-se o Brasil com os EUA, percebe-se um maior desenvolvimento na cultura norte-americana quanto ao disclosure de desempenho e da remuneração de dirigentes. Contudo, mesmo com todo o esforço existente nos EUA, estudiosos examinaram se os indivíduos usam efetivamente as informações providas pelas OSFL e identificaram que muitas pessoas tendem a não checar esses anúncios divulgados (Gordon, Knock, \& Neely, 2009; Silverman, 2009). No Brasil, em 2015, 74\% dos respondentes da Pesquisa Doação Brasil afirmaram que sempre buscam informações sobre as instituições antes de doar (IDIS \& Gallup, 2015).

\subsection{Problema e objetivo da pesquisa}

O processo de disclosure é direcionado para o atendimento das necessidades dos stakeholders, pois visa demonstrar se a OSFL atinge as expectativas ou os resultados por eles esperados. Para que as informações divulgadas sejam efetivas é primordial à OSFL compreender quais são estas expectativas e resultados desejados pelas partes interessadas, correspondendo apropriadamente às preocupações destas e construa uma relação de confiança e legitimidade (Balser \& McClusky, 2005; Fletcher, Guthrie, Steane, Roos, \& Pike, 2003). 
Dessa forma, quando a OSFL presta conta dos elementos importantes para os stakeholders, mesmo quando realizada de forma voluntária, consegue fortalecer sua reputação e legitimidade (Balser \& McClusky, 2005). Afinal, os recursos físicos e financeiros da organização são itens que não são necessariamente previsíveis ou controláveis e, precisam ser tratados com transparência no relacionamento entre a organização e suas partes interessadas.

Diversas pesquisas buscaram aliar a divulgação de informações pelas OSFL com o comportamento dos doadores. Apesar de estudos identificarem que existe relação entre disclosure de informações de desempenho e as doações (Gandia, 2011; Mañas \& Medeiros, 2012; Saunah, Ruhaya, Yap, \& Raja Adzrin, 2012; Sloan, 2008; Trussel \& Parsons, 2007) e, disclosure da remuneração de dirigentes e as doações (Baber, Daniel, \& Roberts, 2002; Balsam \& Harris, 2014; Galle \& Walker, 2013; Grasse et al., 2014; Nikolova, 2013), a maioria dos estudos foram realizados em países desenvolvidos como Estados Unidos (EUA) e Reino Unido. Ademais, no Brasil, normalmente a relação entre a relevância da prestação de contas e as doações recebidas pela OSFL se referem a investimentos provenientes de instituições e não de indivíduos, contrariando os achados de pesquisas realizadas em países mais desenvolvidos (Tinkelman, 1998).

Nos EUA, o disclosure do setor sem fins lucrativos é feito por meio da Receita Federal (Internal Revenue Service Form 990) e agências que buscam auxiliar o doador com comunicados que possam subsidiar as decisões de doação e, adicionalmente à divulgação de informações sobre o desempenho das OSFL, estabelecem padrões para accountability dessas instituições. No Brasil, agências similares que promovam disclosure na esfera sem fins lucrativos são escassas.

Diante desse panorama, Cruz (2010) relata que é difícil buscar estabelecer uma relação entre o comportamento dos doadores brasileiros com o disclosure das informações contábeis, visto a dificuldade de obtenção destas informações. A autora supracitada, em consonância a Oliveira (2009), relata que, apesar de as OSFL declararem que consideram a divulgação de informações contábeis importante, elas mesmas procedem de forma antagônica ao discurso.

Assim, uma das limitações presentes para o desenvolvimento de estudos direcionados à compreensão da utilidade da contabilidade de OSFL para os doadores no Brasil é o baixo índice de disclosure dos relatórios contábeis dessas entidades, bem como outras informações que os doadores também declaram considerar em suas decisões que não são divulgadas (Milani Filho, 2008). Portanto, no Brasil essa comunicação tem baixo poder explicativo aos doadores individuais (Cruz, 2010). 
Percebe-se que a prestação de contas no terceiro setor no Brasil apresenta características que a distingue dos países mais desenvolvidos, pois existe pouca tradição de disclosure das informações contábeis para os usuários. Também, quase não existem instituições que divulgam informações sobre o desempenho das entidades sem fins lucrativos e as demonstrações contábeis são estruturadas, em essência, de forma semelhante à adotada para organizações com fins lucrativos (Cruz, 2010).

Mesmo a informação contábil ser relatada como fator considerado na decisão do doador quanto à destinação dos recursos nas OSFL, esta fica condicionada à disponibilidade da referida informação ao investidor social.

O cenário, em que estão inseridas as OSFL no Brasil, consiste em doadores com restrições de acesso às notícias do desempenho organizacional e, principalmente, referente à remuneração de dirigentes. Todo o discurso acerca do problema enfrentado pelos doadores para acesso às informações das OSFL no Brasil destaca a ênfase do artigo publicado no Mobiliza (2016), sobre os resultados da Pesquisa Doação Brasil, principalmente em relação aos não doadores, pois verificaram razões pelas quais os indivíduos não doam. Os achados identificaram depoimentos de falta de confiança nas OSFL e os de não se sensibilizar à causa. Salientam a necessidade de transparência, com a abertura de contas para demonstrar como os recursos estão sendo usados, com o objetivo de manter os doadores individuais comprometidos com a OSFL, visto que parte dos não doadores já o foi anteriormente.

Os doadores buscam se resguardar identificando se a OSFL é segura, bem administrada e que os valores transferidos à organização serão utilizados de modo a cumprir o fim social para o qual a OSFL se dedica. Contudo, se os doadores não sentirem confiança de que a organização destina adequadamente os recursos recebidos, é provável que a doação não ocorra (Pereira, 2006).

A transparência pelo disclosure é um desafio para OSFL, pois é importante para essas organizações saber quais informações divulgar. Para isso, a Contabilidade, como é a "linguagem dos negócios" pode auxiliar na divulgação dessas informações para ter o efeito esperado no comportamento do doador para o volume doado e para a continuidade da OSFL.

Cruz (2010) relata que quanto maior a reputação da entidade, maior a demanda do doador e, consequentemente, maiores contribuições este fará. Existe, portanto, uma relação positiva entre a reputação e as doações. A reputação corporativa pode ser construída a partir da transparência sobre como a organização utiliza seus recursos, inclusive divulgando a remuneração do dirigente. Além disso, pode-se considerar também que, em face de 
determinadas informações adicionais, doadores podem ser influenciados em seu comportamento de modo a aumentar o volume de contribuição.

OSFL podem, por meio de divulgação voluntária, comunicar "atributos" da instituição que gere no doador a influência para a aprovação social da organização por parte deste, com o objetivo de contribuir e manter a relação social organização-doador. Com isso, aumenta a possibilidade de angariar maior volume de recursos e da mesma forma, amplia a probabilidade de manter a doação futura. Cialdini e Trost (1998) intitulam esse comportamento como compliance, e compreendem que o indivíduo, quando ocorre o compliance, é incentivado a responder de algum modo desejado ou favorável a um pedido.

Um dos princípios psicológicos que influenciam o comportamento de decisões de compliance é o preceito de se conformar às direções de autoridade legítima (Cialdini \& Trost, 1998). Neste sentido, compreende-se que empresas solidárias apoiadoras às OSFL são autoridades legitimamente constituídas pelos doadores quando são conhecidas como dignas, ou seja, atendam aos princípios éticos e morais mínimos. Portanto, quando divulgadas em requisições de doação pelas OSFL, estas empresas podem atuar como influenciadoras e afetar a decisão do doador, tanto no volume quanto na propensão de contribuir futuramente.

Diante das argumentações anteriores, verifica-se a relevância do disclosure pela OSFL, principalmente no que tange à divulgação da remuneração dos dirigentes das organizações. Contudo, quando os doadores não buscam ou não possuem acesso a estas informações antes de doar, a captação de recursos pelas OSFL deve considerar outros fatores. Neste sentido, a influência social pelo disclosure de informações sobre empresas solidárias apoiadoras da OSFL, pode persuadir a decisão do doador e, consequentemente, o desempenho organizacional. Assim, a questão de pesquisa deste estudo é: Qual o efeito do disclosure voluntário de empresas solidárias apoiadoras e da remuneração de dirigentes de OSFL na decisão de doadores individuais?

O objetivo desta pesquisa é verificar se essas duas formas de disclosure afetam a decisão de doadores individuais em um contexto de divulgação voluntária, examinando-se tanto o efeito principal de cada tipo de disclosure, quanto ao seu efeito interativo.

O fator disclosure de remuneração do dirigente foi considerado neste estudo devido à relevância ressaltada pelos doadores nos EUA (Balsam \& Harris, 2014) e no Brasil (IDIS \& Gallup, 2015) sobre informações de como a OSFL, para a qual pretendem doar ou continuar doando, aplica seus recursos.

O fator influência social, representado pelo compliance, considera a existência de um cenário no Brasil não favorável aos doadores quanto a obtenção da informação de 
remuneração do dirigente. Assim, entende-se que a divulgação voluntária da empresa solidária apoiadora, por parte da OSFL, é importante quando aquela é conhecida e bem-vista pelo doador, gerando a conformidade sobre este para com o pedido de doação da OSFL ou para continuar contribuindo com a mesma.

Assim, este estudo enucia a seguinte tese: O disclosure voluntário de empresa solidária apoiadora e da remuneração pela OSFL possui efeito positivo na propensão de doação futura e no volume de contribuição na decisão do doador individual.

\subsection{Justificativa da pesquisa e contribuições do estudo}

Em primeiro lugar, esta pesquisa se justifica pela importância das OSFL que compõem o Terceiro Setor. Scheunemann e Rheinheimer (2013) relatam que o Terceiro Setor representa $8 \%$ da economia mundial, responsável por US\$ 1,1 trilhão de movimentação anual, com 19 milhões de pessoas empregadas nestas organizações. Assim, vislumbrar sobre os determinantes das doações é importante porque OSFL fornecem serviços cruciais para muitas pessoas, gerindo recursos públicos (Nikolova, 2013), além de se consistir em um movimento mundial e alvo de discussão em várias áreas. Outra questão se refere à manutenção das atividades da OSFL de forma sustentável, continuando a contribuir com suas ações de cunho social e auxiliando o Governo em diversas atividades. Consequentemente, a sociedade também é beneficiada, pois pode ser considerada como um ator fundamental para a OSFL, como consumidora e doadora.

Continuamente à importância das OSFL, em segundo lugar, como este estudo tem como foco em OSFL "donativas" (receita proveniente principalmente de doações) (Hansmann, 1987a), ressalta-se a relevância das doações para as OSFL. Uma OSFL é estabelecida para servir em uma missão pública, havendo a necessidade de balancear entre manter suas atividades e ganhar dinheiro suficiente para cobrir os custos administrativos. Contudo, as OSFL são limitadas ao acesso de capital, pois não podem levantar recursos pela emissão de títulos de capital, elas dependem de doações e dívidas, retendo ganhos para esse propósito, que oferecem suporte menor em resposta do que os títulos de capital do mercado (Hansmann, 1987b; Steinwald \& Neuhauser, 1970).

Em terceiro lugar, faz-se necessário abordar as preocupações do doador individual que não é beneficiário dos serviços prestados pela OSFL para a qual contribui e dos fatores que influenciam as doações individuais. Nesta linha argumentativa, compreende-se que o doador 
não possui contato com beneficiários e, portanto, não está habilitado para determinar se as empresas fizeram o seu trabalho, muito menos se o fizeram bem feito. Isso é pautado por Fama \& Jensen (1983) e Hansmann (1987a) ao afirmarem que, para este tipo de doador, não é fácil determinar se a doação está sendo direcionada para o propósito para o qual foi feita.

Em quarto lugar, esta pesquisa busca incrementar o conhecimento acerca da relação entre problemas de agência, que tem sido foco central da pesquisa acadêmica nas últimas décadas. As investigações acerca da teoria de agência iniciam com Berle e Means (1932), ao abordarem que com a separação entre propriedade e controle, os gestores possuem acesso a informações que os stakeholders não conseguem obter sem que o gestor decida divulgar (assimetria informacional). Consequentemente, outros autores continuaram os estudos na perspectiva da Teoria de Agência e da assimetria informacional, destacando-se ao explicarem questões decorrentes como a possibilidade de risco moral (forma de oportunismo que surge apenas depois que é efetivado um contrato) e seleção adversa (quando a informação não é disponibilizada uniformemente entre o principal e o agente) (Demsetz \& Lehn, 1985; Grossman \& Hart, 1983; Jensen \& Meckling, 1976; Milgrom, 1981; Milgrom \& Roberts, 1992). Trabalhos empíricos sobre a remuneração dos executivos sem fins lucrativos geralmente são desenhados a partir da teoria de agência (Ben-Ner e Ren 2010; Gray e Benson 2003; Miller 2002; Olson 2000) e, esta pesquisa objetiva agregar conhecimento com foco em remuneração de dirigentes e as doações que a OSFL arrecada.

Neste sentido, em quinto lugar decorre a necessidade do disclosure contábil nas organizações, pois o papel da divulgação é relevante para atenuar os problemas de informação e o conflito de agência. Quando regulamentado, o conhecimento financeiro fornece informes valiosos para os investidores. Além disso, há evidências de que estes visualizam também as divulgações voluntárias (Healy \& Palepu, 2001).

Em OSFL, detalhes informacionais da situação financeira e de desempenho social auxiliam a decisão dos doadores, haja vista que fornecem dados relevantes sobre o cumprimento da missão social destas organizações, agindo como forma de demonstrar responsabilidade. Assim, em sexto lugar, considera-se a importância do estudo do disclosure voluntário em OSFL, pois ao revelar detalhes de como a organização utiliza seus recursos pode construir a confiança da comunidade (Gandia, 2011). Saxton e Guo (2011) descrevem que o disclosure, especialmente em matéria de finanças e desempenho, constitui o centro dos debates contemporâneos sobre a criação de um setor sem fins lucrativos mais aberto e responsável, mas que esta perspectiva de estudo ainda é recente. 
No geral, não só a divulgação ajuda as organizações a se conectarem com os doadores que compartilham suas preferências, mas, no conjunto, a divulgação voluntária, como no mercado de capitais (Healy \& Palepu, 2001), desempenha um papel fundamental na redução das assimetrias de informação. Além disso, através da divulgação voluntária de dados financeiros e relacionados com o desempenho pertinentes, organizações podem sinalizar a sua eficiência, eficácia, credibilidade, capacidade de resposta, e, mais importante, a sua prestação de contas, para as partes interessadas atuais e potenciais. Portanto, mesmo diante de um cenário no Brasil em que o disclosure de muitas informações não é uma exigência legal, argumenta-se que as organizações têm o dever de serem transparentes. A divulgação completa deve, neste sentido, ser vista como uma extensão natural do objetivo organizacional (Saxton, Jenn-Shyong Kuo, \& Ho, 2012).

Agrega-se à justificativa desta pesquisa o fato de OSFL possuírem como característica a não possibilidade de distribuição de superávit, que influencia o uso e a efetividade de mecanismos de incentivos nestas organizações, bem como as restrições estabelecidas em lei, modificando as perspectivas tanto para as organizações que buscam certificações e isenções fiscais e seus dirigentes, como para seus stakeholders. Em função disso, em sétimo lugar, busca-se estudar a relevância do disclosure especificamente da remuneração de dirigentes de OSFL.

Assim como a mudança ocorrida nos Estados Unidos das formas de operações das OSFL em relação à remuneração dos dirigentes (Barragato, 2002), o Brasil perpassa uma fase em que começa a ampliar o escopo e o entendimento acerca de remuneração de dirigentes em OSFL, com o pronunciamento explícito em leis de modo permissivo sobre a possibilidade de remunerar dirigentes e a existência de diversificações quanto à legislação brasileira para as diferentes formas de atuações e certificações das OSFL (Brasil, 1961, 1999, 2009, 2013, 2014a).

Essa importância de se estabelecer regras restritivas ao volume de pagamento efetuado pelas OSFL aos seus dirigentes e a necessidade de se assegurar que a compensação paga não seja excessiva, com que se preocupa a legislação brasileira, também foi ressaltada por estudiosos, ao relatarem que o desafio para OSFL é compensar os executivos, a fim de motivar o desempenho, mantendo o foco na realização da missão (Frumkin \& Keating, 2010).

De forma geral, a introdução de práticas de remuneração em OSFL tem como ponto crítico a discussão ética associada à finalidade destas organizações e à manutenção de uma relação de credibilidade junto às diversas partes interessadas. Compreender quais os aspectos 
que devem ser levados em consideração quando se pensa em termos de recompensa para OSFL requerem maior estudo e análise, visto que geram dúvida quanto à solução para a competitividade por talentos nestas organizações sem conflitar com os interesses dos stakeholders.

Em oitavo lugar, há pesquisas que abordam variáveis relacionadas à influência social no processo de doação, pois a subjetividade está incluída no processo de avaliação de uma OSFL por parte do doador. Estas normalmente recebem apoio de empresas solidárias que têm consciência da importância do trabalho que estas organizações desenvolvem. O presente estudo busca evidenciar a importância da divulgação da empresa solidária apoiadora (quando possui referências dignas da ética e da moral) para a arrecadação de doações em OSFL donativas, visto que conexões mais fortes podem refletir mais laços sociais formais e informais e um maior nível de legitimidade, capacidade e status social, gerando compliance sobre o doador individual.

Em nono lugar, evidencia-se a importância do estudo do compliance, que é uma das principais facetas da influência social psicológica, que estuda o gerenciamento de conceitos individuais. Compliance consiste na sintonia do indivíduo responder ou consentir a um determinado modo de comunicação, um pedido ou requisição (Cialdini \& Trost, 1998). Neste estudo, o foco é direcionado à forma explícita de compliance, em que existe um pedido direto do solicitante, ou seja, pedido de doação feito pela OSFL.

Em décimo lugar, salienta-se a escassez de estudos na área. Esta pesquisa contribui para ampliar o escopo sobre remuneração e incentivos no setor sem fins lucrativos, visto que ainda são poucos trabalhos direcionados em entender a relação entre a remuneração de dirigentes e as doações recebidas e o compliance exercido pela divulgação de empresas solidárias apoiadoras sobre os doadores na arena sem fins lucrativos (Barragato, 2002; Galle \& Walker, 2013; Sanders, 2001). A discussão sobre remuneração no setor sem fins lucrativos preconiza a relevância da necessidade de remunerar adequadamente o dirigente para que este possa se dedicar integralmente às atividades da organização.

Adicionalmente, como afirma Gounaris (2005), existe evidência empírica para apoiar o papel essencial que a confiança pode influenciar as relações entre empresas e consumidores. Contudo, poucos estudos empíricos têm abordado o papel da confiança em relação aos relacionamentos entre OSFL e doadores (Sargeant \& Lee, 2004) e sobre a percepção dos doadores em relação à organização destinatária da doação e o papel que as OSFL podem desempenhar para estimular o comportamento do doador em doar (Sargeant, Ford, \& West, 2006). 
Neste sentido, os fatores considerados por este estudo - disclosure da remuneração do dirigente e influência social exercida pela empresa solidária apoiadora da OSFL pelo compliance são relevantes no entendimento das motivações que impulsionam o valor das contribuições por parte do doador, pois como afirmam Sargeant et al. (2006), a maioria dos estudos relacionam a decisão de doar ou não, em vez de explorar os fatores que motivam o valor das doações. Diante disso, argumentam que não está claro até que ponto esses fatores podem ter impacto sobre as doações diretas ou serem mediadas por meio de construtos como a confiança.

\subsection{Estrutura da pesquisa}

A presente tese está estruturada em cinco seções. A seção introdutória contém uma abordagem inicial do tema e do contexto que se desenvolve nesta tese, a questão e objetivo de pesquisa, a enunciação da tese, além da justificativa e contribuições do estudo sobre remuneração de dirigentes em OSFL.

$\mathrm{Na}$ sequência, tem-se o referencial teórico que suporta a investigação, sendo abordados os arcabouços teóricos centrais e essenciais à exploração da problematização pesquisada. Nesta vertente, na segunda seção, busca-se expor sobre a caracterização e importância de OSFL, o papel do disclosure na literatura contábil e em OSFL, assim como tratar da influência social como fator relevante na avaliação de OSFL pelo doador. Além disso, nesta seção foram elaboradas as hipóteses da pesquisa.

Os procedimentos metodológicos realizados para desenvolvimento deste estudo estão descritos na terceira seção, sendo explicitados itens como planejamento da pesquisa, variáveis da pesquisa e validação e protocolo do experimento.

$\mathrm{Na}$ quarta seção, apresentam-se as análises dos resultados da pesquisa, composta pela análise descritiva, análise das hipóteses apresentadas e verificação de relações adicionais e com as variáveis de controle. Por fim, na última seção, descreve-se a conclusão do presente estudo. 


\section{REFERENCIAL TEÓRICO}

Este capítulo aborda a fundamentação teórica do estudo, elencando inicialmente aspectos gerais sobre as Organizações Sem Fins Lucrativos (OSFL). A seguir trata o disclosure na literatura contábil e em OSFL, com ênfase para o disclosure de remuneração de dirigentes em OSFL. Por fim, evidencia a influência social na subjetividade de avaliação do doador sobre a OSFL em decisões de doação. Assim, buscou-se a partir da literatura sobre OSFL, disclosure de remuneração e influência social desenvolver a construção das hipóteses da presente pesquisa.

\subsection{Organizações sem fins lucrativos (OSFL)}

As Organizações sem Fins Lucrativos (OSFL) constituem instituições privadas que possuem como missão perspectivas de cunho social e, devido a esta finalidade, são percebidas como detentoras de legitimidade para se unir ao Estado ou substituí-lo em atuações de investimentos e manutenção de atividades de caráter social. São percebidas, portanto, como uma "via eficaz para eliminar a ineficiência da burocracia estatal e assegurar a eficácia dos serviços públicos" (Fischer \& Falconer, 1998, p. 14).

As OSFL possuem missões declaradas que normalmente incorporam múltiplos objetivos sociais. A longo prazo, estas organizações se esforçam para cumprir suas missões e responder a seus stakeholders (Oster, 1998), enquanto que a curto prazo podem maximizar despesas para um determinado projeto (Baber et al., 2002), focar na produção, nos gastos, na quantidade e/ou na qualidade dos serviços prestados (Nikolova, 2013). O Quadro 1 a seguir apresenta as principais características das OSFL.

Quadro 1 - Principais características das OSFL

\begin{tabular}{|c|c|c|}
\hline & Objetivos Institucionais & Provocar mudanças sociais. \\
\hline 2) & $\begin{array}{lcr}\text { Principais } & \text { fontes } & \text { de } \\
\text { recursos } & \text { financeiros } & \text { e } \\
\text { materiais } & & \\
\end{array}$ & $\begin{array}{l}\text { Doações, contribuições, subvenções e prestação de } \\
\text { serviço comunitário. }\end{array}$ \\
\hline & Superávit & $\begin{array}{l}\text { Meio para atingir os objetivos institucionais e não } \\
\text { um fim. }\end{array}$ \\
\hline & Patrimônio/Resultados & Não há participação/distribuição aos pr \\
\hline 5) & $\begin{array}{l}\text { Aspectos fiscais } \\
\text { tributários }\end{array}$ & Normalmente são imunes ou isentas. \\
\hline 6) & $\begin{array}{l}\text { Mensuração do resultado } \\
\text { social }\end{array}$ & $\begin{array}{l}\text { Difícil de ser mensurado monetária } \\
\text { economicamente. }\end{array}$ \\
\hline
\end{tabular}

Fonte: Olak (2000, p.28). 
Em contraste com empresas de maximização de lucro que visualizam o fornecimento de produtos e qualidade do produto apenas como um meio para atingir um fim (maximização do lucro), as OSFL têm como objetivo final fornecer determinados serviços e produtos com qualidade (Speckbacher, 2012).

As OSFL definidas estrutural/operacional, segundo a ONU e utilizada também nas pesquisas do IBGE, são caracterizadas por serem privadas, sem fins lucrativos, institucionalizadas ou formais, autônomas e voluntárias. Esta segundo Falconer (1999) constitui uma referência amplamente aceita e utilizada nos cenários nacional e internacional.

Outra categorização para as OSFL é apresentada por Hansmann (1987a) com duas características principais: (1) pela variedade de receita e (2) pela maneira que são controladas. Ao tratar da variedade de receita, as OSFL são subdivididas em "Donativas" e "Comerciais". A categorização das OSFL pela maneira que são controladas se relaciona à denominação "Mútuas" e "Empreendedoras". Além disso, pode haver combinação das características para fins de classificação, podendo uma OSFL ser categorizada em: Donativa Mútua; Donativa Empreendedora; Comercial Mútua; ou Comercial Empreendedora (Hansmann, 1987a).

No Brasil as OSFL são caracterizadas de acordo com o Cempre do IBGE, que se fundamenta na metodologia do Handbook on non-profit institutions in the system of national accounts, elaborado pela Divisão de Estatística da Organização das Nações Unidas - ONU, em conjunto com a Universidade John Hopkins, em 2002, e por legislação: a Lei n. 10.406/2002 e Lei n. 10.825/2003 vigentes no país, conforme apresentado na Figura 1. 


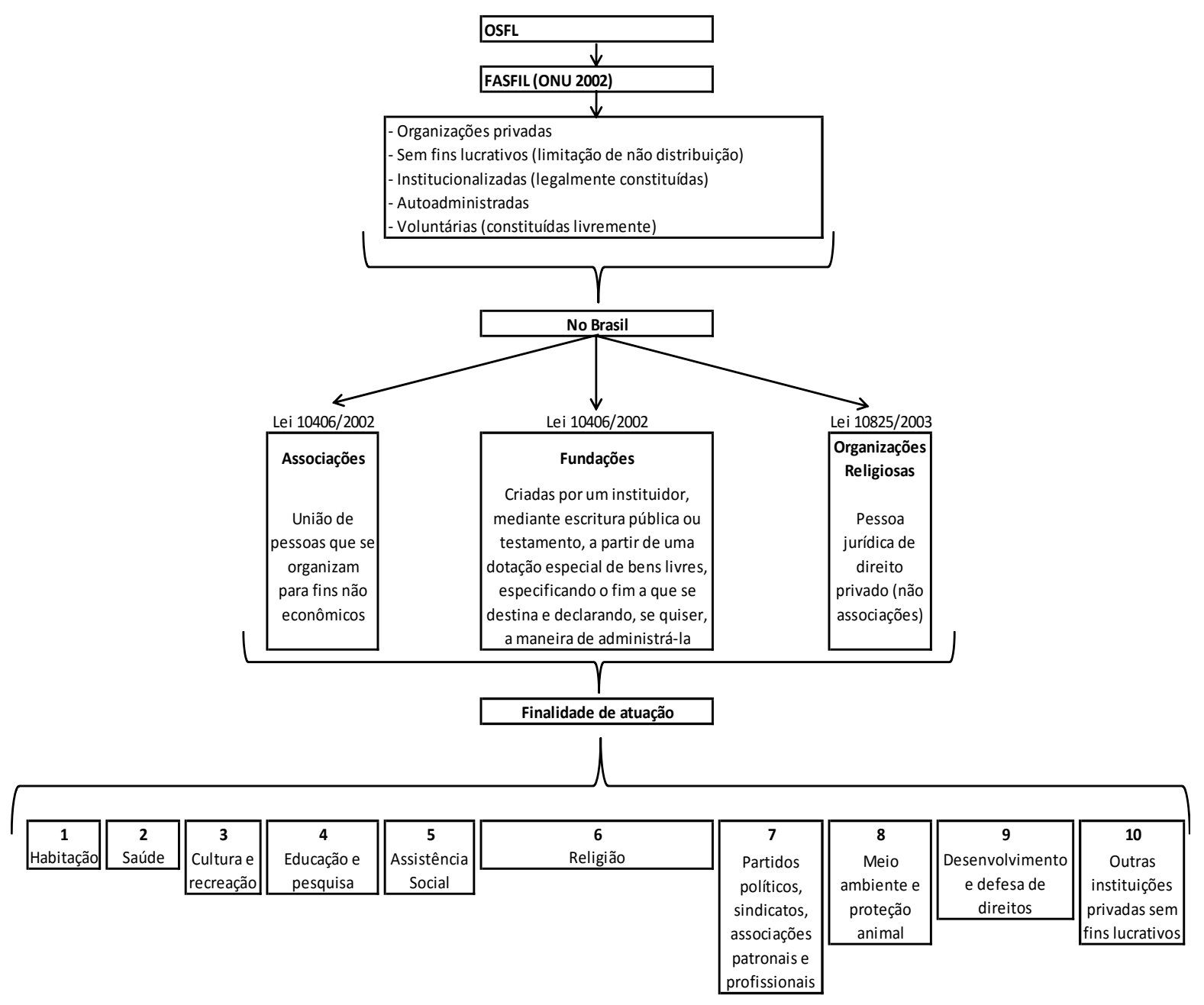

Figura 1 - Caracterização das OSFL no Brasil

Fonte: Adaptado de IBGE e Leis n. 10.406/2002 e n. 10.825/2003.

Conforme apresentado na Figura 1, são consideradas OSFL as organizações existentes no Brasil que se enquadrem, simultaneamente, nos cinco seguintes critérios: (a) privadas, que não pertencem ao Estado; (b) sem fins lucrativos, isto é, organizações que não distribuem superávits excedentes entre os proprietários ou dirigentes, além de não possuírem objetivo primordial de existência a geração de lucros - podendo gerá-los, desde que sejam reaplicados nas atividades fins; (c) institucionalizadas ou formais, que significam legalmente constituídas; (d) autônomas, ou seja, autoadministradas ou passíveis de gerir suas próprias atividades; e (e) voluntárias, podendo ser constituídas livremente por qualquer grupo de pessoas e que envolvem algum tipo de participação voluntária, quer pelo uso do trabalho voluntário (não remunerado) ou por serem expressão da vontade do empreendedor (não compulsórias). 
No cenário brasileiro, três figuras jurídicas são decorrentes dos critérios de classificação das OSFL descritos anteriormente, conforme Novo Código Civil: associações, fundações e organizações religiosas. O Art. 53 da Lei n. 10.406/2002 descreve que associações são constituídas pela união de pessoas organizadas com um mesmo fim, não econômico.

As fundações dependem de um instituidor para serem criadas, devendo ser feita por meio de escritura pública ou testamento, a partir de uma dotação especial de bens livres, especificando o fim a que se destina. O instituidor poderá declarar se desejar, a maneira como a fundação deverá ser administrada. A terceira figura são as organizações religiosas que passaram a ser consideradas a partir da Lei n. 10.825/2003, estabelecendo-as como pessoas jurídicas de direito privado.

A legislação (Brasil, 2002, 2003) trata também de outra figura jurídica que são os partidos políticos. Contudo, este estudo se alicerçou na classificação de Fasfil do IBGE que está em consonância com outros autores (Falconer, 1999; Fernandes, 1994; IPEA, 2008) que entendem que os partidos políticos não fazem parte do terceiro setor por não atenderem as características de autonomia de gestão e independência de governo.

As OSFL podem ainda ser divididas conforme área de atuação, como o demonstrado na Figura 1, que constitui a segregação apresentada pelo IBGE: habitação; saúde; cultura e recreação; educação e pesquisa; assistência social; religião; partidos políticos, sindicatos, associações patronais e profissionais; meio ambiente e proteção animal; desenvolvimento e defesa de direitos; e outras instituições privadas sem fins lucrativos.

Uma vez que a OSFL foi constituída formalmente, esta pode requerer títulos, certificados ou qualificações como forma de reconhecimento governamental, podendo obtêlos em todas as esferas do governo. Anteriormente, existia a possibilidade das seguintes certificações e qualificações: Título de Utilidade Pública Federal (UPF), Registro no Conselho Nacional de Assistência Social (CNAS), Certificado de Entidade Beneficente de Assistência Social (CEBAS), Organização Social (OS) e Organização da Sociedade Civil de Interesse Público (OSCIP). A partir da Lei n. 12.101/2009, é possível a obtenção de: Organização Social (OS), Organização da Sociedade Civil de Interesse Público (OSCIP), Certificado de Entidade Beneficente de Assistência Social (CEBAS - MDS), Certificado de Entidade Beneficente de Saúde (MS) e Certificado de Entidade Beneficente de Educação (MEC). Para obtenção ou renovação desses títulos, existem alguns pré-requisitos estabelecidos na lei que rege cada título que a organização deve seguir (CFC, 2008). 
Organização social (OS) é uma qualificação outorgada pela administração pública a uma OSFL, que exerce atividades de interesse público. Essa qualificação permite à organização receber recursos orçamentários, após ser firmado um contrato de gestão. A lei federal n. 9.637/98 estabelece que o Poder Executivo poderá qualificar como OS pessoas jurídicas de direito privado, sem fins lucrativos, cujas atividades sociais sejam dirigidas ao ensino, à pesquisa científica, ao desenvolvimento tecnológico, à proteção e preservação do meio ambiente, à cultura e à saúde, elencando, ainda, os requisitos para tal outorga.

A qualificação de OSCIP confere a possibilidade de remunerar dirigentes, de firmar um termo de parceria com o Poder Público, sendo um procedimento de obtenção da qualificação centralizado e simplificado, com critérios objetivos. Além disso, a organização pode receber doações de pessoas jurídicas, dedutíveis até o limite de $2 \%$ do lucro operacional, pode receber bens apreendidos, abandonados ou disponíveis, por meio da Secretaria da Receita Federal.

A Certificação das Entidades Beneficentes é concedida pelo Governo Federal às instituições privadas sem fins lucrativos que atuam na área social, educacional e da saúde. $\mathrm{O}$ Novo Marco Regulatório ou Marco Zero, a partir da Lei n. 13.109/2014, trouxe grandes mudanças, principalmente para organizações com Certificação de Entidade Beneficente. Para ter essa certificação, é obrigatório atendimento de $60 \%$ no mínimo pelo Sistema Único de Saúde (SUS) se a organização for da saúde, conceder pelo menos uma bolsa integral de estudo se for da área da educação ou, atender gratuitamente quando for de assistência social.

$\mathrm{Na}$ questão tributária, a Lei n. 12.101/2009, alterada pelas Leis n. 12.868/2013 e n. 13.204/2015, garantem, para organizações com Certificado de Entidade Beneficente (MDS, MS e MEC), a possibilidade de remunerar os dirigentes sem perder os benefícios, receber doações dedutíveis do Imposto de Renda (IR) e bens apreendidos pela Receita Federal (RF) que, antes, somente eram concedidos às OSCIPs. As OSFL com esta certificação, ainda reduzem em cerca de $28 \%$ dos tributos sobre a Folha de Pagamento (20\% da cota patronal, 1 a 3\% do Risco de Acidente do Trabalho (RAT), 6\% aproximadamente de terceiros e 1\% de PIS). O certificado ainda garante às OSFL a isenção de outros tributos, entre eles o CSLL (Contribuição Sobre o Lucro Líquido) e a Contribuição para Financiamento da Seguridade Social (COFINS) de 3\% sobre a receita.

As OSFL de modo geral também são privilegiadas, além dos benefícios tributários concedidos para cada certificação e qualificação, em relação ao pagamento dos impostos. Os impostos incluídos na imunidade tributária são aqueles relativos ao patrimônio, renda e 
serviço das fundações e associações que se enquadram nas regras conforme exigência legal citadas anteriormente, estando distribuídos nas três esferas governamentais.

De forma geral, as OSFL possuem natureza jurídica e se caracterizam, principalmente, pela não distribuição de superávits e por não estarem sujeitas ao controle estatal. Toda sua receita deve ser reinvestida na instituição, seja para melhorias na manutenção física ou para o desenvolvimento de ações sociais. Assim, conforme a NBC T 10.19:

10.19.1.3 - As entidades sem finalidade de lucro são aquelas em que o resultado positivo não é destinado aos detentores do patrimônio líquido e o lucro ou prejuízo são denominados, respectivamente, de superávit ou déficit.

10.19.1.4 - As entidades sem finalidade de lucros exercem atividades assistenciais, de saúde, educacionais, técnicas científicas, esportivas, religiosas, políticas, culturais, beneficentes, sociais, de conselhos de classe e outras, administrando pessoas, coisas, e interesses coexistentes e coordenados em torno de um patrimônio com finalidade comum ou comunitária.

10.19.1.5 - Essas entidades são constituídas sob a forma de fundações públicas ou privadas, ou sociedades civis, nas categorias de entidades sindicais, culturais, associações de classe, partidos políticos, ordem dos advogados, conselhos federais, regionais e seccionais de profissões liberais, clubes esportivos não comerciais e outras entidades enquadradas no conceito do item 10.19.1.4. (CFC, 1999).

Os estudos em OSFL se iniciam na década de cinquenta por meio da teoria econômica com foco no comportamento filantrópico destas organizações, pois até essa época, o setor sem fins lucrativos era composto basicamente de entidades de caridade dependentes de contribuições filantrópicas (donativos, roupas, dinheiro, comida, etc.) (Hansmann, 1987a).

A partir de 1960, o setor desenvolve nova estrutura e desempenho e assume importância para a política pública e o papel das OSFL começa a ser discutido, em comparação com as indústrias com fins lucrativos e organizações públicas (Hansmann, 1987a).

Assim, as teorias econômicas sobre as OSFL se desenvolveram direcionadas a duas vertentes: o papel e o comportamento destas organizações. Contudo, para Hansmann (1987a), essas questões (papel e comportamento) não podem ser separadas e os estudos relevantes no setor apenas se iniciaram a partir de 1970.

As OSFL tendem a focar na sua missão, e no sucesso de seus valores antes do sucesso com sua riqueza. Estas organizações, ao contrário de organizações com fins lucrativos, são limitadas ao acesso ao capital. As OSFL não podem levantar capital pela emissão de títulos de capital. Elas dependem de dívidas e doações, que oferecem suporte menor em resposta do que títulos de capital do mercado (Hansmann, 1987a). 
Para isso, devem-se relacionar com diversos públicos e de formas diferenciadas: solicitação de doações, realização de bazares, cursos, estabelecimento de parcerias e alianças estratégicas, autorização para o uso de marcas e promoção de eventos são alguns exemplos dessas relações que envolvem diversos aspectos, inclusive jurídicos (Ciconello \& Moraes, 2014).

A aproximação entre o setor empresarial e as OSFL resulta em parcerias com o objetivo de apoiar os projetos desenvolvidos por estas organizações. A relação com os diversos públicos e as parcerias com empresas diversas se constitui em uma importante fonte de financiamento para as OSFL (Bettiol Junior, 2005).

Uma OSFL pode obter recursos por meio de doações, contribuições ou subvenções. $\mathrm{O}$ Conselho Federal de Contabilidade (CFC, 2008, p. 301, 302) entende doações como "transferências gratuitas, em caráter definitivo, de recursos financeiros ou do direito de propriedade e bens com finalidade de custeio, investimento e imobilizações sem contrapartida do beneficiário"; e contribuições como

\footnotetext{
transferências correntes ou de capital previstas na lei orçamentária ou especial concedidas por entes governamentais à autarquia, fundações e a entidades sem fins lucrativos, sendo: transferências correntes destinadas à aplicação em custeio e a manutenção destas, sem contrapartida de bens ou serviços da beneficiaria dos recursos e; transferência de capital: destinadas aos investimentos ou inversões financeiras. (CFC, 2008, p. 301, 302).
}

Já as subvenções são “contribuições pecuniárias concedidas por órgãos do setor público à entidade, previstas em lei orçamentária e tem como objetivo cobrir despesas com a manutenção e custeio, com ou sem contraprestação de bens ou serviços pela entidade beneficiada" (CFC 2008, p. 301, 302).

As fontes de financiamento das atividades desenvolvidas pelas OSFL não se limitam apenas às contribuições recebidas do setor empresarial. Um conjunto pulverizado de pessoas físicas associadas ou não à organização também compõem os mantenedores das atividades prestadas pelas OSFL e, consequentemente, integram as partes interessadas (stakeholders) da organização (Mindlin, 2009). O Governo Federal do Brasil incentiva fiscalmente o doador, seja Pessoa Física ou Pessoa Jurídica, por meio de diversas legislações, decretos e medidas provisórias, contribuindo, assim, para uma maior arrecadação de recursos pelas OSFL, conforme Quadro 3 e 4 a seguir. 
Quadro 2 - Incentivos fiscais federais concedidos a Pessoas Jurídicas

\begin{tabular}{|c|c|c|c|}
\hline Incentivo & Benefício & Limite & Retorno \\
\hline $\begin{array}{l}\text { 1) Incentivo ao Esporte } \\
\text { (Lei n. } 11.438 / 2006 \text { ) }\end{array}$ & $\begin{array}{l}\text { Dedução de } 100 \% \text { do valor doado do IR } \\
\text { devido }\end{array}$ & $\begin{array}{c}1 \% \text { do IR devido sem } \\
\text { o adicional }\end{array}$ & $100 \%$ \\
\hline $\begin{array}{l}\text { 2) Lei Rouanet (Cultura) } \\
\text { (Lei n. 8.313/1991; Decreto n. } \\
5.761 / 2006 \text { ) }\end{array}$ & $\begin{array}{c}\text { Dedução de } 100 \% \text { do valor doado do IR } \\
\text { devido ou dedução de parte do valor } \\
\text { doado (30-40\%) do IR devido e } 100 \% \\
\text { como despesa operacional }\end{array}$ & $\begin{array}{l}4 \% \text { do IR devido sem } \\
\text { o adicional* }\end{array}$ & $\begin{array}{l}\text { Entre } \\
64 \% \text { e } \\
100 \% \\
\end{array}$ \\
\hline $\begin{array}{l}\text { 3) Lei do Audiovisual } \\
\text { (Lei n. 8.685/1993; Decreto n. } \\
6.304 / 2007 \text { ) }\end{array}$ & $\begin{array}{c}\text { Dedução de } 100 \% \text { do valor doado como } \\
\text { despesa operacional (do IR) e/ou dedução } \\
\text { de } 100 \% \text { do valor doado do IR devido }\end{array}$ & $\begin{array}{l}3 \% \text { ou } 4 \% \text { do IR } \\
\text { devido sem o } \\
\text { adicional } *\end{array}$ & $\begin{array}{l}\text { Entre } \\
100 \% \text { e } \\
125 \%\end{array}$ \\
\hline $\begin{array}{l}\text { 4) FUNCINE } \\
\text { (MP } 2.228 / 2001)\end{array}$ & $\begin{array}{c}\text { Dedução de } 100 \% \text { do valor doado do IR } \\
\text { devido }\end{array}$ & $\begin{array}{l}3 \% \text { do IR devido sem } \\
\text { o adicional* }\end{array}$ & $100 \%$ \\
\hline $\begin{array}{l}\text { 5) Fundos dos Direitos da } \\
\text { Criança e do Adolescente } \\
\text { (Lei n. 8.069/1990; IN SRF } \\
\text { 267/2002) }\end{array}$ & $\begin{array}{c}\text { Dedução de } 100 \% \text { do valor doado do IR } \\
\text { devido }\end{array}$ & $1 \%$ do IR devido & $100 \%$ \\
\hline $\begin{array}{l}\text { 6) Fundos dos Idosos } \\
\text { (Lei n. 12.213/2010; IN SRF } \\
1.131 / 2011 \text { ) }\end{array}$ & $\begin{array}{c}\text { Dedução de } 100 \% \text { do valor doado do IR } \\
\text { devido }\end{array}$ & $1 \%$ do IR devido & $100 \%$ \\
\hline $\begin{array}{l}\text { 7) Doação a entidades sociais } \\
\text { (TUP ou OSCIP) } \\
\text { (Lei n. 9.249/1995; MP 2.158- } \\
\text { 35/2001) }\end{array}$ & $\begin{array}{c}\text { Dedução como despesa operacional do IR } \\
\text { e da CSLL }\end{array}$ & $\begin{array}{l}2 \% \text { do lucro } \\
\text { operacional }\end{array}$ & $34 \%$ \\
\hline $\begin{array}{l}\text { 8) PRONON - Programa } \\
\text { Nacional de Apoio à Atenção } \\
\text { Oncológica } \\
\text { (Lei n. } 12.715 / 2012 \text { ) }\end{array}$ & $\begin{array}{c}\text { Dedução de } 100 \% \text { do valor doado do IR } \\
\text { devido }\end{array}$ & $\begin{array}{l}1 \% \text { do IR devido sem } \\
\text { o adicional }\end{array}$ & $100 \%$ \\
\hline $\begin{array}{l}\text { 9) PRONAS/PCD - Programa } \\
\text { Nacional de Apoio à Atenção } \\
\text { da Saúde da Pessoa com } \\
\text { Deficiência } \\
\text { (Lei n. } 12.715 / 2012 \text { ) }\end{array}$ & $\begin{array}{c}\text { Dedução de } 100 \% \text { do valor doado do IR } \\
\text { devido }\end{array}$ & $\begin{array}{c}1 \% \text { do IR devido sem } \\
\text { o adicional }\end{array}$ & $100 \%$ \\
\hline
\end{tabular}

*No Paraná existe o incentivo fiscal estadual - Lei estadual de incentivo à cultura (Lei n. 17.043/2011 e Decreto

n. 8.679/2013). Existe também a destinação do ICMS à projetos culturais. ${ }^{1}$

${ }^{1}$ Espaço geográfico de onde a amostra da pesquisa é proveniente. 
Quadro 3 - Incentivos fiscais federais concedidos a Pessoas Físicas

\begin{tabular}{|c|c|c|c|}
\hline Incentivo & Benefício & Limite & Retorno \\
\hline $\begin{array}{l}\text { 1) Incentivo ao Esporte } \\
\text { (Lei n. } 11.438 / 2006)\end{array}$ & $\begin{array}{c}\text { Dedução de } 100 \% \text { do valor doado do IR } \\
\text { devido }\end{array}$ & $6 \%$ do IR devido* & $100 \%$ \\
\hline $\begin{array}{l}\text { 2) Lei Rouanet (Cultura) } \\
\text { (Lei n. } 8.313 / 1991 \text {; } \\
\text { Decreto n. 5.761/2006) }\end{array}$ & $\begin{array}{c}\text { Dedução de } 100 \% \text { do valor doado do IR } \\
\text { devido }\end{array}$ & $6 \%$ do IR devido* & $100 \%$ \\
\hline $\begin{array}{l}\text { 3) Lei do Audiovisual } \\
\text { (Lei n. 8.685/1993; } \\
\text { Decreto n. 6.304/2007) }\end{array}$ & $\begin{array}{c}\text { Dedução de } 100 \% \text { do valor doado do IR } \\
\text { devido }\end{array}$ & $6 \%$ do IR devido* & $\begin{array}{c}\text { Entre } 100 \% \text { e } \\
125 \%\end{array}$ \\
\hline $\begin{array}{l}\text { 4) FUNCINE } \\
(\mathrm{MP} 2.228 / 2001)\end{array}$ & $\begin{array}{c}\text { Dedução de } 100 \% \text { do valor doado do IR } \\
\text { devido }\end{array}$ & $6 \%$ do IR devido* & $100 \%$ \\
\hline $\begin{array}{l}\text { 5) Fundos dos Direitos da } \\
\text { Criança e do Adolescente } \\
\text { (Lei n. 8.069/1990; IN SRF } \\
\text { 258/2002) }\end{array}$ & $\begin{array}{c}\text { Dedução de } 100 \% \text { do valor doado do IR } \\
\text { devido }\end{array}$ & $6 \%$ do IR devido* & $100 \%$ \\
\hline $\begin{array}{l}\text { 6) Fundos dos Idosos } \\
\text { (Lei n. 12.213/2010; IN } \\
\text { SRF 1.131/2011) }\end{array}$ & $\begin{array}{c}\text { Dedução de } 100 \% \text { do valor doado do IR } \\
\text { devido }\end{array}$ & $6 \%$ do IR devido* & $100 \%$ \\
\hline $\begin{array}{l}\text { 7) PRONON - Programa } \\
\text { Nacional de Apoio à } \\
\text { Atenção Oncológica } \\
\text { (MP 563/2012; Lei n. } \\
12.715 / 2012) \\
\end{array}$ & $\begin{array}{c}\text { Dedução de } 100 \% \text { do valor doado do IR } \\
\text { devido }\end{array}$ & $1 \%$ do IR devido & $80 \%$ ou $100 \%$ \\
\hline \begin{tabular}{|l|} 
9) PRONAS/PCD \\
Programa Nacional de \\
Apoio à Atenção da Saúde \\
da Pessoa com Deficiência \\
(MP 563/2012; Lei n. \\
12.715/2012)
\end{tabular} & $\begin{array}{c}\text { Dedução de } 100 \% \text { do valor doado do IR } \\
\text { devido }\end{array}$ & $1 \%$ do IR devido & $80 \%$ ou $100 \%$ \\
\hline
\end{tabular}

*No Paraná existe o incentivo fiscal estadual - Lei estadual de incentivo à cultura (Lei n. 17.043/2011 e Decreto n. 8.679/2013). Existe também a destinação do ICMS à projetos culturais.

Sob a perspectiva mundial, as empresas contribuem somente com um montante de $10 \%$ do total de recursos recebidos por OSFL. As pessoas físicas, notadamente da classe média, são as responsáveis pelos $90 \%$ restantes. No Brasil, a classe média contribui com menos de $28 \%$, do total das doações, o que representa, em média, 23 reais por ano. As fundações doam 40\% (sendo que também podem receber doações de pessoas físicas), o governo repassa $26 \%$ e o resto são provenientes de bingos beneficentes, leilões e eventos (Kanitz, 2015).

Neste contexto, as partes interessadas de OSFL podem estar presentes na organização, como mantenedores, gestores, voluntários e funcionários, ou podem ser externos à organização, como doadores, mídia, parceiros, governo, associações, organizações representativas de determinados segmentos sociais e a população em geral (Balser \& McClusky, 2005; Krashinsky, 1997). 
OSFL se beneficiam de muitos subsídios implícitos e explícitos (federal, estadual, local, taxas postais especiais, taxas do sistema empregatício favoráveis) (Hansmann, 1987a). Fama e Jensen (1983) sugerem que estes subsídios são em grande parte responsáveis pela proliferação de OSFL, principalmente em ramos que competem com organizações com fins lucrativos. Contudo, Hansmann (1987a) relata que o escopo dos subsídios parece ter sido ajustado ao longo dos anos para incluir as novas indústrias em que as OSFL se proliferaram, e isso, é razão para duvidar que estes subsídios têm muito efeito sobre a propagação destas indústrias.

Se os stakeholders cessarem a disponibilização de recursos, essas instituições certamente terão dificuldade em se manter ativas, podendo, na maioria dos casos deixarem de existir. Sob tal perspectiva, os doadores são considerados como clientes dessas organizações, pois apesar de serem vistos inicialmente como provedores de recursos, esses também possuem motivações e expectativas definidas em contraprestação à disponibilização de recursos. Dessa forma, compreende-se que os doadores podem querer verificar se os objetivos que eles manifestaram ao disponibilizar recursos para a instituição foram devidamente atendidos (Moore, 2003).

A priori não existe razão para acreditar que a maximização de lucros é uma meta razoável para imputar para OSFL. Mais comumente, OSFL são assumidas como maximizadoras da qualidade e/ou quantidade dos serviços que produzem (Hansmann, 1987a). Presume-se isso pelo fato das OSFL serem caracterizadas por relações de confiança entre a organização e seus stakeholders, que são facilitados e fortalecidos pela restrição de não distribuição conforme já descrito anteriormente (Speckbacher, 2012).

Doadores esperam que as OSFL atuem de forma eficiente e eficaz no seu desempenho (Handy et al., 2010; Tinkelman \& Donabedian, 2007). Além disso, consideram como questão relevante para a doação para caridade a confiança de que o dinheiro esteja sendo bem administrado (Balsam \& Harris, 2014).

O processo em busca de legitimidade ocorre, pois mesmo no setor sem fins lucrativos existe a separação entre propriedade e controle. Como no caso das empresas públicas, as OSFL são caracterizadas por uma separação entre propriedade e controle. A separação é ainda mais grave em entidades sem fins lucrativos, pois estas não possuem vários mecanismos de controle, como a pressão da votação dos acionistas como ocorre em lucrativas. Como resultado os gerentes desfrutam de uma grande dose de liberdade para executar a organização como bem entendem. Se assim for, também podem ter um incentivo a menos para extrair excesso de remuneração da organização, pois o dinheiro está essencialmente sob o controle 
deles de qualquer maneira (Core, Guay, \& Verdi, 2006; Fama \& Jensen, 1983; Klick \& Sitkoff, 2008).

Bogart (1995) estabelece que em uma OSFL o "principal" consiste nos doadores, quadro de diretores e outros agentes externos e os dirigentes são os "agentes" da organização. Essa separação entre a propriedade e controle faz com que haja a necessidade de monitoramento das ações do agente por parte do principal e o estabelecimento de remuneração adequada para alinhamento de interesses (Ballantine, Forker, \& Greenwood, 2008; Ben-Ner, Ren, \& Paulson, 2010; Gray \& Benson, 2003; Miller, 2002; Olson, 2000).

Neste sentido, a forma corporativa de OSFL, com a característica de não distribuição pode ser considerada uma estrutura de Governança Corporativa que mitiga os incentivos do agente em agir contrariamente aos interesses do principal (Williamson, 1979). Isso ocorre, pois o doador fica no papel do principal, que não pode monitorar facilmente o desempenho do agente (OSFL), que foi contratada para prover um bem ou serviço, (Hansmann, 1987a) sendo representado pelo dirigente.

Hansmann (1981) desenvolveu uma pesquisa para estudar o modelo de maximização de qualidade e quantidade em uma organização artística e, segundo o autor, o modelo assume que a organização opera em condições de falha de contrato e isso leva a aderência do limite de não distribuição. A restrição de não distribuição reduz os incentivos àqueles no controle da organização a explorar em seu próprio favorecimento (Speckbacher, 2012).

Segundo Hansmann (1987a) uma OSFL é interpretada como um contrato que especifica: (1) o montante de compensação a ser recebido pelo dirigente; (2) o restante do preço de compra deve ser para custear outros gastos com produção; (3) o dirigente irá gastar o mínimo de esforço observado. Todas as características do contrato são assumidas como sendo verificáveis pelo consumidor.

Quando o doador não é o beneficiário dos serviços ou bens, este não está habilitado ou é pouco habilitado para determinar se a OSFL fez seu trabalho, muito menos se o trabalho foi bem feito. Assim, doadores buscarão doar para organizações em que percebam que nenhuma parte de seus ganhos líquidos é utilizado em benefício privado (Glaeser, 2007).

Quando o principal não consegue observar totalmente as ações de um agente que está desempenhando um serviço contratado, o agente tende a ter vantagem informacional sobre o principal. Esta vantagem informacional cria o que vem sendo tratado na literatura econômica como o dilema principal-agente (Berle \& Means, 1932; Grossman \& Hart, 1983; Nikolova, 2013). 
A preferência entre OSFL concorrentes feita por doadores ou potenciais doadores ocorre de forma semelhante à escolha dos investidores no âmbito do mercado de capitais, ou seja, ambos os tipos de decisões são motivados pela maximização da utilidade esperada pelo doador ou investidor (Cruz, 2010).

$\mathrm{Na}$ decisão em que ocorre no mercado de capitais, todas as possíveis opções de investimento têm como foco um resultado pecuniário. A utilidade desse resultado geralmente não é dependente do tipo de atividade exercida pela empresa investida, pois investidores podem formar carteiras de investimentos fundamentados na sua preferência de risco e retorno. Já na decisão do doador sobre qual OSFL doar, a utilidade está atrelada com os objetivos e atividades desenvolvidas pela OSFL (assistência a crianças portadoras de deficiência ou auxílio e cuidado aos idosos). Portanto, a natureza da entidade orienta doadores nas suas escolhas (Cruz, 2010).

De acordo com Fama \& Jensen (1983), os problemas de agência entre doadores e dirigentes em OSFL são semelhantes àqueles de outras organizações. A delegação de autoridade para tomada de decisão e o desalinhamento de interesses entre o principal e o agente geram esses conflitos de agência, que são acentuados pela assimetria informacional. No setor sem fins lucrativos existe forte assimetria informacional entre o dirigente da organização e os seus investidores sociais (stakeholders) (Cruz, 2010).

Glaeser (2006) reflete que em OSFL, os investidores dessas organizações não ganham, explicitamente, direitos de controle sobre as instituições. Esse direito é detido pela diretoria que, na maioria das vezes é composta apenas parcialmente por doadores e seus representantes. Assim, em OSFL, o processo de prestação de contas da diretoria aos doadores se distigue do realizado nas empresas com fins lucrativos, em que os acionistas ou quotistas são detentores de parcelas do capital.

Além disso, mesmo que normas legais que tratam da necessidade de observância da missão por parte da OSFL, não exigem que os dirigentes atuem segundo os interesses de investidores ou doadores. Como resultado, a administração dessas organizações apresenta um maior grau de autonomia e os doadores frequentemente exercem pouca influência sobre as entidades, principalmente no que tange aos doadores individuais (Glaeser, 2006). Deste modo, a escolha da organização para a qual serão alocados os recursos ganha relevância no setor sem fins lucrativos.

Compreende-se, portanto, que as OSFL que apresentarem melhor atendimento às necessidades informacionais de doadores atuais ou aos doadores potencias terão maiores condições de captar um maior volume de recursos financeiros e não financeiros. Trussel e 
Parsons (2007) também entendem que se os doadores são inseguros sobre como os dirigentes de OSFL usam os recursos recebidos, aqueles tendem a diminuir o fornecimento dessas contribuições ou buscar por uma organização que transmita essa segurança.

A confiança ou a segurança requisitada pelo doador pode ser conquistada pela OSFL ao efetuar o disclosure de informação de desempenho e alocação de recursos. Inicialmente, há a exigência legal quando à divulgação de informações por OSFL. De acordo com as Normas Brasileiras de Contabilidade - NBC T 10.19.2.5, os registros contábeis de OSFL devem evidenciar as contas de receitas e despesas, superávit ou déficit, de forma segregada, quando identificáveis por tipo de atividade, tais como educação, saúde, assistência social, técnica científica, comercial, industrial ou de prestação de serviços (CFC, 2008). Além disso, o artigo 54 do Código Civil de 2002 estabelece que o estatuto das OSFL conterá quais são as fontes de recursos para sua continuidade (Brasil, 2002a).

Cruz, Corrar, e Slomski (2008) ressaltam que as informações geradas pela contabilidade não devem conter apenas aspectos financeiros e econômicos, mesmo sendo estes os constituintes do núcleo central da contabilidade. A OSFL também deve divulgar os aspectos físicos e de produtividade, ou seja, efetuar o disclosure de todas as informações que permitam a avaliação da sua situação, provendo os seus usuários (como os doadores) de elementos importantes para avaliação da organização.

Mesmo com as exigências legais, nem sempre as informações requeridas para fins de divulgação são suficientes para atender às necessidades dos doadores. Uma OSFL pode ter muitas reputações definidas de acordo com cada atributo e stakeholder. Nesta perspectiva, Healy e Palepu (2001) relatam que pode ser importante para a OSFL efetuar disclosure voluntário de outros informes que achar pertinente, como o caso da remuneração dos dirigentes, uma vez que isso advém da assimetria de informação e do conflito da agência entre dirigentes e investidores externos, como os doadores, no caso das OSFL.

O disclosure voluntário também é relevante quando o doador é pessoa física, pois como relatam Herrero, Cruz, e Merino (2002), o que motiva o indivíduo a doar é pouco focado em resultados mensuráveis e doador não compreende o objeto de trabalho da organização. Além disso, muitas vezes o dirigente tem dificuldade em comunicar o objeto de trabalho da organização. 


\subsection{Disclosure Contábil}

\subsubsection{Literatura do disclosure de informações contábeis}

Healy e Palepu (2001) relatam que empresários e empresas já existentes buscam atrair investidores para financiar as suas ideias de negócio. Embora ambos os poupadores e os empresários queiram fazer negócios entre si, na economia, a harmonização das oportunidades de investimento é restringida por pelo menos duas razões. Primeiro, os empresários geralmente têm uma melhor informação do que os investidores sobre o valor das oportunidades de investimentos e incentivos a superestimar o seu valor. Os investidores, portanto, enfrentam o problema de assimetria informacional em relação aos gestores dos empreendimentos. Em segundo lugar, uma vez que ocorre o investimento, os empresários podem ter incentivos para expropriar suas economias, criando um problema de agência.

O problema de agência surge porque os investidores normalmente não intencionam de desempenhar um papel ativo na gestão do negócio e tendem a delegar essa responsabilidade para o empresário. Consequentemente, uma vez que os poupadores investem seus recursos em um negócio de risco que envolve uma série de tomada de decisões, os empresários podem não decidir em consonância com o que decidiriam os investidores (Jensen \& Meckling, 1976).

Neste sentido, a falta de informação e problemas de incentivo impede a alocação eficiente de recursos em uma economia de mercado de capitais. Neste sentido, a divulgação e as instituições criadas para facilitar a divulgação credível entre gestores e investidores desempenham um papel importante na mitigação desses problemas (Healy \& Palepu, 2001).

A divulgação corporativa é, portanto, fundamental para o funcionamento de um mercado de capitais eficiente. As empresas fornecem divulgação através de relatórios financeiros regulamentados, incluindo as demonstrações financeiras, notas de rodapé, discussão e análise de gestão, e outros arquivamentos regulatórios. Além disso, algumas empresas se envolvem em comunicação voluntária, tais como previsões de gestão, apresentações de analistas e teleconferências, comunicados de imprensa, sites da internet, e outros relatórios corporativos. Adicionalmente às divulgações realizadas pela própria empresa, o disclosure pode ocorrer por meio de intermediários de informação, tais como analistas financeiros, especialistas do setor e da imprensa financeira (Healy \& Palepu, 2001).

O full disclosure descrito por Beyer, Cohen, Lys, e Walther (2010) é restringido por fatores como custo de divulgação e a incerteza dos investidores sobre a posse de informação dos dirigentes (Dye, 2001; Leuz \& Wysocki, 2007; Verrecchia, 2001). Verrecchia (1983) 
defende que a divulgação sofre influência dos custos de emissão de informativos e que a motivação para o disclosure surge quando o efeito de determinada notícia conhecida pelo investidor gera valor na empresa. $\mathrm{O}$ objetivo, portanto do gestor se relaciona à maximização de valor da empresa no mercado.

Quando o gestor restringe determinada informação, compreende-se que o custo do disclosure é superior aos benefícios que seriam proporcionados ao valor da empresa pela liberação da mesma. E, segundo Consoni (2014), os estudos sobre a divulgação corporativa tem se esforçado para compreender quais incentivos fazem com que os dirigentes não divulguem determinadas informações aos investidores.

Lima (2009) estudou a relação entre divulgação e custo de capital de terceiros, resultando que um maior nível de disclosure reduz o custo de capital de terceiros. Em seu estudo, Lopes e Alencar (2010) desenvolveram um Índice de Disclosure Brasileiro (IDB) para estudar as cinquenta empresas mais líquidas da BM\&FBovespa. Os achados refletem que um maior nível de divulgação reduz a assimetria informacional, proporcionando aumento na liquidez da ação, maior demanda por ações da empresa ou ainda redução do risco de estimativa.

O papel da divulgação é relevante para atenuar os problemas de informação e o conflito de agência. Contudo, permeia também na literatura estudos que tratam da relevância da devida regulamentação do relatório financeiro apresentado. Nos EUA, as empresas e o acesso aos mercados de capitais são obrigados a seguir regras de divulgação estabelecidas pela Securities and Exchange Commission (SEC).

As normas de contabilidade regulam as opções de relatórios disponíveis para os gestores na apresentação de demonstrações financeiras da empresa. Este tipo de regulação potencialmente reduz os custos de processamento para os usuários das demonstrações financeiras, fornecendo uma linguagem comumente aceita que os gerentes podem usar para se comunicar com os investidores (Healy \& Palepu, 2001). Estes documentos de pesquisa que a contabilidade exige em termos de divulgação variam sistematicamente com as características da empresa e do país (Alford, Jones, Leftwich, \& Zmijewski, 1993; Ball, Kothari, \& Robin, 2000; Collins \& Kothari, 1989; Easton \& Zmijewski, 1989).

O pressuposto das normas é adicionar valor para os investidores ou outras partes interessadas. Para identificar se há relevância a regulamentação dos relatórios financeiros divulgados pelas empresas, vários estudos buscam compreender se essa regulamentação da divulgação para resolver os problemas de informação e o conflito de agência em mercados de capitais é eficaz (Healy \& Palepu, 2001). 
Uma possível explicação para a regulação é discutido por Leftwich (1980) e Watts e Zimmerman (1986), ao proporem que a regulamentação da divulgação é motivada por outros fatores além das preocupações com as falhas de mercado. Os autores citam como exemplo os reguladores, que podem estar preocupados com o bem-estar dos investidores financeiramente sofisticados. Com a criação de requisitos mínimos de informação, os reguladores reduzem a lacuna desta entre informados e desinformados. Esta explicação para a divulgação implica que o objetivo de a regular é redistribuir a riqueza, ao invés de melhorar a eficiência econômica. Desta forma, os investidores sofisticados poderiam optar por reduzir a lacuna de informação, investindo em conhecimento financeiro ou contratar os serviços de intermediários.

A evidência acima sugere que a informação financeira regulamentada fornece dados valiosos para os investidores (Healy \& Palepu, 2001). Em concordância, Beaver (1980) pesquisou a relevância do valor das informações apresentadas sob proposta de novas normas de informação financeira. Como resultados, associando os ganhos e os preços das ações ou retorno como uma medida da relevância de valor, encontrou que a maioria dos padrões recentes gera informações contábeis que possuem valor relevante.

A investigação sobre a divulgação enfoca o papel das informações dos relatórios financeiros para os mercados de capitais (Healy e Palepu, 1993, 1995). Estudos documentam que as divulgações voluntárias estão associadas com o desempenho das ações, bid-ask spreads, custo de capital, cobertura de analistas e propriedade institucional. Há evidências de que os investidores visualizam divulgações voluntárias, tais como previsões de gestão, como uma informação credível (Healy \& Palepu, 2001).

Outro achado foi encontrado por Barry e Brown $(1985,1986)$ e por Merton (1987), que concluíram em seus estudos que, quando há uma assimetria de informações entre gestores e investidores externos, os gerentes podem diminuir o seu custo de capital, reduzindo o risco de informações por meio de uma maior divulgação voluntária.

Os gestores que agem no interesse dos acionistas existentes têm incentivos para fornecer divulgações voluntárias de redução de custos de contratação associados com compensação de ações para os novos empregados. Para a compensação, é mais provável que seja uma forma eficiente de remuneração dos administradores e proprietários, se os preços das ações são uma estimativa precisa de valores. Caso contrário, os gestores vão exigir uma vantagem adicional para recompensá-los a suportar qualquer risco associado com misvaluation. Assim, as empresas que utilizam extensivamente compensação de ações são, portanto, susceptíveis de fornecer divulgação adicional para reduzir o risco de misvaluation (Healy \& Palepu, 2001). 
Outro estudo desenvolvido por Aboody e Kasznik (2000) concluiu que as empresas atrasam a divulgação de boas notícias e aceleraram a liberação de más notícias antes de períodos de atribuição de opções de ações, de acordo com os gestores a tomar decisões de divulgação para aumentar a remuneração baseada em ações. Já Miller e Piotroski (2000) constataram que os gerentes das empresas em situações de resposta são mais propensos a fornecer as previsões de lucros se eles têm compensação de opção de ações em maior risco.

Vários pesquisadores acreditam que as decisões das empresas em divulgar voluntariamente informações para os investidores são influenciadas pela preocupação de que essas informações possam prejudicar a sua posição competitiva nos mercados de produtos. (ver Darrough \& Stoughton, 1990; Darrough, 1993; Feltham \& Xie, 1992; Gigler, 1994; Newman \& Sansing, 1993; Verrecchia, 1983; Wagenhofer, 1990). Esses estudos concluem que as empresas obtêm incentivo para não divulgar informações que irá reduzir a sua posição competitiva, mesmo se tornar mais caro para levantar capital adicional. No entanto, esse incentivo parece ser sensível à natureza da competição, em especial, se as empresas enfrentam concorrentes existentes ou apenas a ameaça de entrada, assim como se as empresas concorrem principalmente com base em decisões de preços ou de capacidade a longo prazo.

Verrecchia (2001) e Dye (2001) preveem que a divulgação voluntária será sempre credível. Na medida em que a divulgação voluntária atenua possíveis problemas no mercado de capitais, isso depende do grau de credibilidade da informação na economia da empresa e se está disponível, mesmo que a partir de outras fontes de divulgações, as informações mínimas de disclosure exigidas.

A internet também fornece gerenciamento com a oportunidade de atender a todos os investidores e para fornecer atualizações diárias de informações importantes. Muitos sites da internet corporativos fornecem uma visão geral do desempenho da empresa, uma avaliação de desempenho, comunicados de imprensa, cotações de ações, frequentes relações com investidores perguntas, previsões de ganhos (por analistas financeiros), bem como os relatórios anuais, relatórios conforme a SEC. O uso crescente da Internet pelos investidores é provável que continue reduzindo os custos da prestação das divulgações voluntárias e, presumivelmente, aumentando a sua oferta (Healy \& Palepu, 2001).

$\mathrm{O}$ aumento do ritmo de empreendedorismo e as mudanças no ambiente econômico provavelmente aumentaram o valor da informação de confiança no mercado de capitais (Healy \& Palepu, 2001). Em um mercado perfeito, as empresas têm incentivos para otimizarem seus negócios, independente dos custos da divulgação voluntária, e para produzirem o nível eficiente de informações para os investidores na economia. 
Leftwich (1980), Watts e Zimmerman (1986), e Beaver (1998) observam que as informações contábeis podem ser vista como um bem público, pois auxiliam os acionistas existentes implicitamente a pagar para a sua produção, mas, por outro lado, as empresas não podem cobrar a utilização das informações divulgadas por parte de potenciais investidores. Estes, portanto, possuem acesso livre às informações que são subsidiadas por acionistas existentes, o que, muitas vezes, leva à subprodução potencial da informação na economia.

Em conclusão, compreende-se que os estudos de divulgação assumem, mesmo em um mercado de capitais eficiente, que os gestores dispõem de mais informações do que os investidores externos sobre o desempenho futuro esperado das suas empresas. Se os regulamentos de auditoria e contabilidade funcionam perfeitamente, as decisões dos gestores contábeis e divulgações comunicam as mudanças na economia de negócios da própria empresa aos investidores externos. Como alternativa, se a regulação da contabilidade e da auditoria são imperfeitos, uma possibilidade mais provável é a ocorrência de trade-off entre a tomada de decisões contábeis e divulgações para comunicar o conhecimento superior de desempenho da empresa por parte dos gestores para os investidores (Healy \& Palepu, 2001).

\subsubsection{Disclosure Contábil em OSFL}

Atender às necessidades informacionais dos doadores, especialmente quando realizadas de forma proativa, aumenta a legitimidade e confiança para com a OSFL, uma vez que recursos físicos e financeiros são elementos importantes para a continuidade da organização e que não são necessariamente previsíveis ou controláveis. Ao contrário, são providos pelos doadores, e devem ser gerenciados por meio de monitoramento e administração por parte destes (Balser \& McClusky, 2005).

O disclosure é voltado para atender às necessidades dos stakeholders, buscando demonstrar o atendimento de suas expectativas ou do alcance dos resultados por eles esperados. Contudo, para que a divulgação de informações seja efetiva, faz-se necessário compreender as reais expectativas dos doadores sobre as atividades exercidas pela organização. As OSFL devem buscar responder às preocupações dos stakeholders, promovendo a construção de uma relação de confiança entre as partes (Balser \& McClusky, 2005; Fletcher et al., 2003).

A essência da informação é a sua capacidade de transformação. A prática de disclosure de informações relevantes realizada por OSFL, independentemente se obrigatória 
ou voluntária, objetiva apresentar aos doadores uma boa reputação organizacional, ou seja, que a missão da instituição foi cumprida e que os recursos confiados a ela foram corretamente utilizados (Carneiro et al., 2011; Cunha \& Matias-Pereira, 2012; Olak \& Nascimento, 2010).

Muitos doadores possuem informação limitada de como uma OSFL opera. Nos EUA, as agências de rating específicas, voltadas para o setor sem fins lucrativos, foram criadas com a expectativa de prover, tanto para doadores, como para potenciais doadores, informação contábil sem viés e facilmente acessível, para auxiliar doadores em melhores decisões sobre para qual organização doar dinheiro (Cnaan, Jones, Dickin, \& Salomon, 2011).

No Brasil, o Tribunal de Contas da União (TCU, 2008) considera a prestação de contas como uma "obrigação social e pública de prestar informações sobre algo pelo qual se é responsável". Em caráter normativo, as OSFL, para fins de disclosure das informações relevantes, devem seguir as orientações do Conselho Federal de Contabilidade (CFC) por meio de Normas Brasileiras de Contabilidade Técnicas (NBC T) específicas. Cabendo a NBC-T 10.4 às fundações, a NBC-T 10.18 às entidades sindicais e associações de classe e a NBC-T 10.19 às OSFL. Além disso, todas essas entidades devem observar as normatizações de aplicação geral, como os Princípios de Contabilidade e demais NBC T's ( Olak \& Nascimento, 2010).

A NBC-T 10.19 estabelece que as demonstrações contábeis, que devem ser elaboradas e divulgadas pela entidade sem finalidade de lucros são: o Balanço Patrimonial, a Demonstração do Resultado, a Demonstração das Mutações do Patrimônio Líquido, a Demonstração dos Fluxos de Caixa e Notas Explicativas.

As OSFL devem divulgar informações sobre seu desempenho, suas ações desenvolvidas, os serviços oferecidos e a forma como seus recursos estão sendo utilizados. $\mathrm{Ou}$ seja, referente ao cumprimento, transparência e responsabilidade das organizações em prestarem contas aos vários envolvidos (membros/ voluntários/ clientes/ fontes financiadoras), não somente legalmente, mas também devido a trabalharem com recursos de terceiros e não possuírem finalidade de lucro (Mosher, 1968).

Três formas de disclosure são possíveis por parte da OSFL: (1) informações obrigatórias previstas em lei; (2) informações explicativas sobre as ações e objetivos da OSFL; e (3) divulgação responsiva, em que a organização considera as necessidades daqueles a quem presta contas. Enquanto a primeira é obrigatória, as duas últimas podem ser divulgadas pela OSFL voluntariamente.

Levando em consideração a existência de uma competição por recursos públicos e privados cada vez maior, devido ao crescimento do setor sem fins lucrativos, as OSFL que 
divulgam informações adicionais às exigidas legalmente, demonstram espontaneamente as ações empreendidas junto à sociedade em geral, evidenciando uma postura ética e moral por parte da organização e seus gestores, e com isso compor a estratégia competitiva da entidade (Carneiro et al., 2011).

Contudo, apesar do esforço por meio de sites oficiais do governo brasileiro, o cenário do país não é efetivo na divulgação de informações das OSFL e os doadores não possuem facilidade de acesso aos dados das instituições por meio de mecanismos formais.

Por meio da prestação de contas, as entidades recebem um reconhecimento público de suas ações e passam a obter maior credibilidade e legitimidade. Ou seja, a transparência é um fator determinante da sua sobrevivência, pois pelo seu caráter público é preciso que estas entidades prestem contas aos investidores sociais das suas atividades desenvolvidas e de que forma seus recursos estão sendo utilizados (Kumar, 1995).

A dificuldade de acesso às informações pode gerar um comportamento não desejado pelas OSFL nos doadores. Buscando compreender empiricamente como o disclosure por parte de OSFL interfere na captação de recursos, diversas investigações buscaram aliar a divulgação de informações por essas entidades com a decisão dos doadores.

Internacionalmente, Khumawala e Gordon (1997) analisaram como doadores individuais utilizam as demonstrações financeiras de OSFL em seu processo de decisão. Para isso, a investigação abordou 216 alunos. Metade da amostra recebeu demonstrações financeiras e informação quantitativa e narrativa das atividades desenvolvidas pela entidade, enquanto a outra metade recebeu somente as três demonstrações financeiras requeridas pelo Statement of Financial Accounting Standards (SFAS). Os resultados desse estudo sugerem que são necessárias modificações nas demonstrações contábeis e, especificamente com relação à informação não financeira, mas os achados indicam que ela é útil no processo de decisão de doação.

Silvergleid (2003) encontrou que indicadores de contabilidade sobre o desempenho de OSFL não são preditores significativos de contribuições privadas. As pessoas não contribuem para causas sociais por acharem que são mal administradas.

Parsons (2001) desenvolveu um experimento de campo que investigou o impacto da informação contábil financeira e do disclosure voluntário sobre as contribuições individuais de doadores para OSFL. Como resultado, a autora concluiu que a divulgação de informações contábeis, quando fornecida diretamente aos potenciais doadores, reduz a incerteza percebida sobre a eficiência das operações, pois doadores inteirados de informações contábeis financeiras favoráveis são mais propensos a fazer doações se eles forem doadores prévios 
daquela instituição. Contudo, no caso de novos doadores, a média de doações dos que receberam informações contábeis financeiras e não financeiras não foi significativamente diferente da média produzida daqueles que não tiveram acesso a estas informações.

Parsons (2007) também desenvolveu um experimento em laboratório com o mesmo objetivo do descrito anteriormente, mas com estudantes da área de negócios de uma universidade norte-americana. Contudo, desta vez solicitou que os participantes avaliassem a utilidade de pedidos de arrecadação de recursos com diferentes tipos de divulgação de informações. Os resultados demonstram que a divulgação das informações não financeiras, nesse caso a descrição das realizações da organização, deve ser útil no processo de decisão de doação.

Trussel e Parsons (2007) desenvolveram uma pesquisa com objetivo de identificar fatores dos relatórios contábeis das entidades sem fins lucrativos que podem impactar doações. Para a realização do estudo, os autores desenvolveram uma estrutura categorizando as demonstrações contábeis em quatro fatores: (1) a eficiência da organização em alocar recursos para os seus programas (eficiência); (2) a estabilidade financeira, definida como a habilidade da instituição para continuar operando no futuro frente a uma diminuição dos recursos (estabilidade financeira); (3) a quantidade de informações disponíveis para os doadores (disponibilidade de informações); e (4) a reputação da entidade (reputação).

Os Resultados de Trussel e Parsons (2007) indicam que o primeiro fator teve uma relação negativa com as doações, enquanto os outros três fatores apresentaram relação positiva com as referidas contribuições. Assim, os autores concluíram que as doações são afetadas pela eficiência, estabilidade financeira, quantidade de informação fornecida, e reputação da OSFL.

Já Sloan (2008) investigou a relação do efeito de notas de ratings recebidos por OSFL dos EUA no comportamento das doações recebidas por estas organizações. Os resultados demonstram uma associação positiva entre as notas de ratings e as contribuições recebidas.

Gandia (2011) estudou se a Internet pode contribuir para divulgação de informações por parte das OSFL. Notou-se que, dentre os resultados de seu estudo realizado em entidades espanholas, níveis mais altos de evidenciação possui relação positiva com o volume de recursos recebidos de doadores.

Atan, Zainon e Wah (2012) buscaram verificar se há relação entre a qualidade da informação divulgada por OSFL e as doações totais recebidas por essas organizações. O estudo foi desenvolvido tendo como base organizações da Malásia e os resultados indicaram 
que o volume total de doações recebidas possui relação positiva com a qualidade da evidenciação promovida.

No Brasil, Pereira (2001) analisou os fatores que motivam o doador brasileiro a fazer doações. Segundo o estudo, as pessoas preferem contribuir para instituições que demonstrem ser transparentes e que transmitam confiança e credibilidade por evidenciarem suas ações e como investem os recursos recebidos.

Cruz et al. (2008, p.14) realizaram uma pesquisa quase experimental buscando identificar se a divulgação de informações contábeis econômicas influenciam nas decisões individuais do doador e na quantia doada para OSFL. O estudo foi desenvolvido com estudantes de Ciências Contábeis de duas universidades brasileiras. Os resultados indicam que o tipo de informação recebida - "uma descrição das realizações e atividades desenvolvidas pela entidade; a Demonstração do Superávit ou Déficit do Exercício (DSDE); ou ambas as informações" - não influenciam nas decisões de doação (fazer ou não a doação) ou na quantia a ser doada. Assim, não foi encontrada diferença estatisticamente significativa entre o número de doações produzidas pelos três diferentes grupos, nem entre o volume de recursos indicado por esses grupos.

Milani Filho (2008) investigou se as organizações filantrópicas de São Paulo divulgam suas demonstrações contábeis exigidas para fins de obtenção de certificação de Entidade Beneficente de Assistência Social (CEBAS) - Balanço Patrimonial; Demonstração do Resultado do Exercício; Demonstração de Mutação do Patrimônio; Demonstração das Origens e Aplicações de Recursos; e notas explicativas; todas as demonstrações relativas aos três últimos anos (Brasil, 1998a). Como resultado, verificou-se que 71,8\% das organizações pesquisadas não disponibilizavam seus relatórios contábeis ao público externo, ou seja, essas entidades divulgavam suas demonstrações contábeis ao governo através da remessa desses relatórios ao referido usuário, no entanto não os evidenciavam por meio de publicação, o que compromete a transparência da instituição em termos de disponibilidade de informações financeiras à sociedade como um todo.

Cruz (2010) em sua tese de doutoramento buscou investigar se a informação contábil é relevante para explicar as doações privadas em OSFL no Brasil, qualificadas como Organizações da Sociedade Civil de Interesse Público (OSCIP). Os resultados indicam que informação contábil é relevante para explicar doações e contribuições privadas oriundas de instituições. Em relação às contribuições de doadores individuais, a autora destaca que no Brasil, a publicação dos relatórios contábeis das organizações do terceiro setor não tem sido prática comum e o custo para obtenção das informações contábeis frente ao valor doado é 
maior para os doadores individuais do que para os institucionais. Além disso, os doadores individuais são menos propensos a examinar a informação contábil que comunica a eficiência operacional da OSCIP antes de fazer uma contribuição.

Cunha e Matias-Pereira (2012) desenvolveram um estudo com o objetivo de identificar até que ponto as informações divulgadas pelas OSFL do Distrito Federal são concernentes à eficiência em alocar recursos aos programas, à estabilidade financeira, à quantidade de Informações disponibilizadas e ao nível de reputação das OSFL, importantes aos doadores segundo Trussel e Parson (2007). Os resultados indicam que a maior parte das OSFL do Distrito Federal não divulga informações mínimas exigidas para obtenção de Cadastro Nacional de Entidades de Utilidade Pública.

Silva, Dockhorn e Scarpin (2012) realizaram um estudo de caso em uma OSFL da região sul do Brasil e notaram que os doadores privados dessa organização, na prestação de contas recebida, levam em conta características como proximidade, confiabilidade e história em maior peso do que os relatórios contábeis.

Portulhak, Delay e Pacheco (2015) encontrou relação positiva entre a prestação de contas realizada por OSFL e o comportamento de doação de indivíduos. Resultado em alinhamento com a relação observada em estudos anteriores, como os de Cruz (2010), Gandia (2011) e Sloan (2008). O autor conclui que a prestação de contas leva ou pode levar esses indivíduos a continuarem doando ou, até mesmo, doarem mais recursos, bem como poderia mudar a postura dos antigos doadores de modo a retomarem o fornecimento de recursos. Assim, a prestação de contas consiste em um elemento significativo de influência positiva para manter, aumentar ou retomar doações.

Zittei, Politelo e Scarpin (2016) buscaram identificar qual o nível de disclosure contábil das OSFL que participam do projeto de Desenvolvimento de Princípios de Transparência e Prestação de Contas - BID. Do total da população de setenta e seis entidades participantes, realizaram análise documental de quinze organizações que divulgavam informações sobre transparência em seus sítios. A pesquisa identificou que a maioria das OSFL não divulga as informações exigidas pelas normas do CPC 26 e NBC T 19.10 ou possuem baixo atendimento destas. Em conclusão, os autores relatam que as OSFL não percebem a relevância da prestação de contas e da transparência.

Portulhak, Vaz, Delay e Pacheco (2017) analisaram a relação entre a qualidade da prestação de contas e a decisão do doador em realizar contribuições. Utilizaram o modelo dos quatro fatores de qualidade (eficiência; estabilidade; quantidade e reputação) de Trussel e Parsons (2007) e a coleta de dados ocorreu por meio de survey com 277 respostas válidas. O 
estudo conclui que há oportunidades para a melhoria da prestação de contas realizada por OSFL e identificou que os doadores consideram os quatro fatores na decisão, inclusive valorizam a reputação da OSFL para continuar doando.

De forma geral, as pesquisas desenvolvidas sobre o disclosure de OSFL buscaram aliar a prestação de contas de OSFL com o recebimento de doações, tendo como objeto as próprias organizações e as informações divulgadas por elas (Atan et al., 2012; Cruz, 2010; Gandia, 2011; Sloan, 2008; Trussel \& Parsons, 2007) ou a realização de experimentos com doadores e alunos (Cruz, Espejo, Gassner, \& Walter, 2010; Parsons, 2001, 2007).

No âmbito da teoria da agência, a informação emanada da contabilidade funciona como um mecanismo que visa atenuar a assimetria informacional e o conflito de agência existente entre o gestor da entidade (agente) e os doadores (principais), que destinam recursos para as OSFL por meio de suas doações e contribuições (Parsons, 2001, 2007).

Apesar disso, Mcdougle e Handy (2014) relatam que a maioria dos doadores (aproximadamente 78\%) não consultam websites de OSFL ou sucursais de informação das agências de rating do setor sem fins lucrativos antes de efetuar doações de caridade. Isso remete à reflexão de que recursos para melhor conectar a OSFL com os membros da comunidade devem ser aplicados em menor de tempo sem se preocupar com tentativas de encontrar padrões contábeis para os divulgar em agências credenciadas, pois esses padrões acabam não checados pela comunidade.

Nos Estados Unidos, onde é desenvolvida a maior parte de pesquisas nessa linha, as OSFL são obrigadas legalmente a fazer com que o formulário 990 da Receita Federal (Internal Revenue Service - IRS Form 990) seja amplamente disponível, inclusive indicando no mesmo os meios utilizados para a sua divulgação. O formulário 990 é um tradicional mecanismo de divulgação de informações contábeis das OSFL. As instituições sem fins lucrativos devem enviar anualmente à Receita Federal norte-americana (Internal Revenue Service - IRS) o formulário 990 (IRS Form990), intitulado "Declaração de Organização Isenta do Imposto de Renda", que é aberto à inspeção pública, e inclui informações provenientes das demonstrações contábeis elaboradas de acordo com os Princípios Contábeis Geralmente Aceitos (Balsam \& Harris, 2014).

Além disso, as informações são divulgadas de forma classificada para auxiliar os doadores na avaliação dos recursos utilizados pelas OSFL nas atividades que realizam, a finalidade da organização (program services) e o quanto desses recursos foram usados nas atividades de apoio (Cruz, 2010). 
As cópias do Formulário 990 entregues à Receita Federal norte-americana pelas OSFL podem ser obtidas em websites de instituições que divulgam informações sobre entidades sem fins lucrativos (American Institute of Philanthropy (AIP), a Better Business Bureau (BBB)/Wise Giving Alliance, e a Charity Navigator), que também têm como propósito auxiliar os indivíduos com informações que os ajudem nas decisões de doação (Balsam \& Harris, 2014).

No Brasil, agências similares na esfera sem fins lucrativos são escassas. Diante desse panorama, Cruz (2010) relata que é difícil prever o comportamento dos doadores brasileiros no que se refere ao uso das informações emanadas da contabilidade. Por isso, as características do terceiro setor no Brasil no que se refere à regulamentação e evidenciação contábil podem comprometer a relevância da informação gerada pela contabilidade para os doadores.

Alves (2005) também verificou que 50\% das OSCIPs pesquisadas não davam publicidade às demonstrações contábeis; 33\%, tornavam públicas através de website; e 17\%, através de jornal local. Quanto ao relatório de atividades, $83 \%$ das entidades não lhe davam publicidade e $17 \%$, tornavam-no público através de website.

Adicionalmente, a estrutura conceitual brasileira aplica os CPCs às demonstrações contábeis de entidades em geral, inclusive sem fins lucrativos, e não prevê objetivos específicos para as demonstrações contábeis das OSFL, como ocorre na estrutura norteamericana (CPC, 2008).

Assim, se a informação contábil relevante é aquela que influencia a decisão do doador quanto à alocação de recursos nas OSFL e, se essa relevância está condicionada à disponibilidade da referida informação a esse investidor social (Cruz, 2010), a transparência e o disclosure são elementos essenciais para contribuir com a própria sobrevivência das organizações. As OSFL “estão inseridas num ambiente competitivo por recursos financeiros e não financeiros e aquelas que melhor atenderem às necessidades dos doadores por informações, terão maior probabilidade de captação desses recursos" (Milani Filho, 2004, p. 9). Contudo, como verificado nos estudos desenvolvidos no âmbito do setor sem fins lucrativos do Brasil, a publicação das demonstrações contábeis não tem sido uma prática comum às diversas instituições que o compõem. Soma-se a isso, o fato de que, em pesquisa desenvolvida no Brasil, IDIS e Gallup (2015) encontraram que a grande maioria dos doadores busca informações sobre a OSFL para a qual pretende doar e, Portulhak, Delay e Pacheco (2015) verificaram que a prestação de contas elaboradas por OSFL constitui uma informação 
relevante na percepção dos doadores, sendo o elemento mais significativo na promoção de influência positiva para manter, aumentar ou retomar doações.

\subsubsection{Disclosure de remuneração de dirigentes em OSFL}

Para os stakeholders, de forma simplista, a filosofia de compensação para uma OSFL reflete uma estratégia fundamentada por parte dos tomadores de decisão da organização a respeito de como a organização vai competir dentro de um mercado cada vez mais competitivo e em permanente mutação (Grasse et al., 2014). Embora existam regras e exigências das partes interessadas e das legislações vigentes quanto aos procedimentos na determinação da remuneração dos dirigentes em OSFL, elas não são susceptíveis de proporcionar total disciplina sobre como as organizações desenvolvem o pacote de remuneração que irão aplicar aos seus dirigentes. As regras oferecem uma forma de segurança para que a OSFL possa-se fundamentar para o estabelecimento da remuneração e incentivos (Manny, 2007).

Apesar da dificuldade ética existente em lidar com a ambiguidade de que, pessoas com poder de influência nas decisões da organização recebem remuneração por sua função executiva na entidade ou pela prestação de serviços específicos, deve-se considerar que a remuneração dos dirigentes consiste em uma contraprestação pelo trabalho que estes exercem em favor da entidade, o que não deveria se confundir com a distribuição de lucros. O conceito de finalidade não lucrativa se define pela não distribuição aos associados, conselheiros, etc., de eventuais excedentes operacionais ou parcelas do patrimônio da associação e pela aplicação integral destes recursos na realização da respectiva missão da organização (Ciconello \& Moraes, 2014).

É importante para as OSFL com perspectivas de gestão que atrelem aos dirigentes um quadro de remuneração atraente, sem que parte dos ganhos líquidos organizacionais sejam utilizados em benefício privado. Speckbacher (2012) retrata essa preocupação elencando três características de OSFL que influenciam o uso e a efetividade de mecanismos de incentivos nestas organizações: (1) falta de medidas contratáveis que não distorça o desempenho global da organização; (2) relevância de identificar a motivação dos funcionários; (3) relações sociais entre a organização e seus stakeholders.

A figura do principal, representado por múltiplos stakeholders no setor sem fins lucrativos, poderia mitigar o problema de agência, porém Galle e Walker (2013) afirmam que 
o conflito entre agentes existe na esfera sem fins lucrativos, permitindo que dirigentes administrem as organizações de uma forma que doadores ou outras partes interessadas possam não aprovar.

A introdução de práticas de remuneração originárias nas organizações do mercado para profissionais que trabalham em OSFL perpassa a questão prática da estrutura e do aprendizado necessário para a implementação de tais práticas. A principal preocupação está na discussão ética associada à finalidade destas organizações e à manutenção de uma relação de credibilidade junto às diversas partes interessadas (Hipólito, 2004).

Neste contexto, a remuneração de OSFL reflete a estratégia racional por parte dos seus tomadores de decisão de como a organização irá competir na dinâmica de mercado em constante mudança (Grasse et al., 2014). Handy e Katz (1998) sugerem que OSFL atraiam indivíduos comprometidos ao oferecer pacotes de compensação que promovam autosseleção entre os dirigentes em potencial.

As diversas formas de desenhos de contratos de remuneração de uma organização sugere que existem diferenças entre as organizações que afetam o comportamento institucional e a natureza dos resultados. Os incentivos providos por uma organização como forma de remuneração de seus executivos devem refletir seus objetivos (Ballou \& Weisbrod, 2003).

Neste sentido, Baber, Daniel e Roberts (2002) usam a estrutura do contrato de agência para analisar a remuneração de dirigentes em OSFL. Os autores encontraram relações estatísticas significantes entre remuneração de dirigentes e mudanças em gastos em programas que geram os objetivos organizacionais.

Entre as OSFL também existe competição pelo talento do executivo. Pacotes de pagamentos competitivos com remuneração mais justa e razoável, ou seja, aquela que balanceia o valor de mercado com o talento do executivo mantendo a confiança da doação do público é componente crítico de sucesso em OSFL (Nikolova, 2013).

Em seu estudo, Balsam e Harris (2014) encontraram que apoiadores reduzem doações para OSFL subsequente ao disclosure de alta compensação do executivo. Este achado também é condizente com o de Galle e Walker (2013) que preveem que os níveis de remuneração mais elevados serão associados com níveis reduzidos de contribuições.

Com salários altos dos executivos, doadores reconsideram suas doações e a redução é maior conforme o montante de compensação reportado pela OSFL. Contudo, quando o doador também é o receptor dos serviços prestados pela organização, as doações caem menos do que em organizações cujo doador não é o beneficiário direto ou indireto (Balsam \& Harris, 
2014). A explicação consiste no fato de que apoiadores que são usuários dos serviços podem avaliar diretamente a qualidade desses serviços e, portanto, possuem menor demanda de relatos financeiros e informações de remuneração de executivos.

$\mathrm{Na}$ análise direta feita por Balsam e Harris (2014) entre a divulgação da remuneração do dirigente e a variação percentual das doações, após o controle de outros fatores encontrados que também podem influenciar as doações, os autores mostram que os apoiadores reduzem doações para organizações sem fins lucrativos subsequentemente à divulgação de alta remuneração dos executivos. Análises adicionais indicam uma relação negativa mais forte em organizações sem fins lucrativos classificadas como mais caridosas e uma relação mais fraca em organizações sem fins lucrativos que prestam serviços a seus doadores.

Galle e Walker (2013) verificaram que a remuneração do presidente é menor em organizações que são mais dependentes de doações correntes como uma forma de receita. Além disso, os autores analisaram o impacto de níveis de remuneração de dirigentes em doações futuras. Como resultado, evidencia-se a associação negativa entre os níveis de remuneração reportados e doações futuras, o que é consistente com a ideia de que os doadores respondem negativamente a remunerações elevadas. Em conclusão, o artigo fornece evidências sugerindo que uma maior dependência de contribuições como uma fonte de financiamento coloca pressão descendente sobre a compensação reportada de dirigentes e que compensação superior divulgada tende a desencorajar doações.

Se o apego dos doadores para com a organização sem fins lucrativos é diminuído pela decepção emocional ou ideológica no pagamento de seu líder, as doações podem reduzir, deixando o dirigente com menos recursos disponíveis para perseguir seus próprios objetivos (Andreoni, 1990). Como resultado, as OSFL estão justamente preocupadas que o aumento da remuneração do dirigente poderia manchar a imagem pública de um grupo ou placa institucional (Oster, 1998).

O status organizacional que a OSFL conquistou com seus projetos também pode servir como um sinal suficiente para determinar o grau de confiabilidade da organização (Handy et al., 2010). Entretanto, Mcdougle (2014) relata que, mesmo quando os doadores expressam ter maior confiança em uma OSFL, isso não é suficiente para eximir completamente os esforços de obter informações sobre o desempenho destas organizações, somente porque possuem percepções favoráveis.

Conforme as argumentações expostas anteriormente sobre remuneração de dirigentes de OSFL e as doações que estas organizações recebem, pode-se compreender que o doador é 
sensível à divulgação da remuneração do dirigente da OSFL e responde negativamente a altos valores.

Contudo, apesar da preocupação existente acerca de como a remuneração pode influenciar as doações que uma OSFL recebe, em se tratando do Brasil, os tempos em que preponderava o entendimento equivocado, principalmente por parte do Poder Público (a remuneração dos dirigentes influenciava nos benefícios fiscais e nos títulos da OSFL), de que entidades sem fins lucrativos (associações e fundações) não devem remunerar seus dirigentes, está em processo de mudança. As justificativas para esta interpretação perpassavam pela questão histórica de que, pessoas que ocupam os cargos de dirigentes de OSFL muitas vezes deveriam atuar de forma voluntária ou gratuita, pelo fato de OSFL não possuírem finalidade lucrativa e pela possibilidade de refletir uma forma disfarçada de distribuição de lucros.

A mudança mais recente em relação à questão sobre remuneração de dirigentes em OSFL foi o advento da Lei n. 12.868/2013. Esta lei possui caráter permissivo de forma explícita de que instituições detentoras da Certificação de Entidades Beneficentes de Assistência Social (CEBAS) remunerem seus dirigentes sem prejudicar os benefícios do CEBAS da instituição (Brasil, 2013).

A Lei n. 12.868/2013 estabeleceu, além da permissão de remuneração, um limite para remuneração de dirigentes estatutários (não empregado, eleito por conselho) de $70 \%$ do valor de remuneração dos servidores do Poder Executivo Federal (R\$ 20.623,57 - 70\% de R\$ 29.462,25) e determinando que, adicionalmente, a soma de todas as remunerações de dirigentes não pode exceder cinco vezes o valor do limite individual (Brasil, 2013).

Além disso, não permite remunerar o dirigente quando este possui parentesco de até terceiro grau com instituidores, diretores, conselheiros, benfeitores ou equivalentes. Ainda, permite remunerar tanto pelo cargo de dirigente como por execução de outra função na instituição (ex. diretor ser remunerado por atuar também como médico na instituição, além da remuneração pelo cargo de dirigente), desde que não haja conflito com a carga horária (Brasil, 2013).

Anteriormente, já havia a liberação de remunerar dirigentes para Organizações da Sociedade Civil de Interesse Público (OSCIP), desde 1999, com a Lei n. 9.790/99 (Brasil, 1999). A lei abre a possibilidade de salários a dirigentes para entidades que adquirirem a qualificação de OSCIP, desde que estes efetivamente atuem na gestão executiva da entidade ou lhe prestem serviços específicos. O artigo 34 da Lei n. 10.637/02 prevê a isenção do imposto de renda a estas organizações quando a remuneração decorrer de vínculo empregatício. Há uma ressalva, no entanto, quanto ao valor do salário, que não pode ser 
superior, em seu valor bruto, ao limite estabelecido para a remuneração de servidores do Poder Executivo Federal ( $\mathrm{R} \$ 20.623,57$ - 70\% de $\mathrm{R} \$ 29.462,25)$ e deve respeitar os valores praticados no mercado de trabalho da região de atuação da entidade.

Independentemente do tipo de organização, quando da decisão ou não de remunerar o dirigente, deve-se declarar em Estatuto Social. Caso não haja o documento, fica vedada a remuneração. Além disso, ressalta-se que explicitamente nunca houve proibição, por parte do Poder Público, que as OSFL retribuíssem financeiramente às atividades de seus dirigentes, mas essa decisão gera consequências em relação aos benefícios fiscais e às titulações concedidos à organização (Ciconello \& Moraes, 2014).

De forma geral, compreende-se que a legislação visa restringir práticas de remuneração de dirigentes que possam caracterizar distribuição de superávits. Por serem caracterizados por relações de confiança entre a organização e seus stakeholders, os incentivos providos por qualquer OSFL sob a forma de compensação a seus dirigentes devem refletir os objetivos da organização (Ballou \& Weisbrod, 2003).

Restringir a remuneração excessiva em OSFL se deve à dependência de doadores como fator de restrição. Estes se preocupam com os níveis de gratificações salariais de dirigentes e respondem, em conjunto, de forma negativa à alta remuneração (Galle \& Walker, 2013). A sensibilidade dos doadores é uma condição necessária, mas não suficiente para a proposição de que a dependência de doações atuais amorteça os níveis de remuneração.

Nos EUA, grupos como o Charity Navigator e o Economic Research Institute possuem informações disponíveis on-line por meio do IRS Form 990, que disponibilizam informações acerca da remuneração de dirigentes de OSFL. Contudo, no Brasil essa prática não é adotada e essas informações não estão facilmente acessíveis ao público em geral. O que os doadores possuem são informações quanto a certificações e titulações deferidas às OSFL e o que se exige destas organizações para obtenção destes títulos.

As OSFL OSCIP não podem atribuir, aos seus dirigentes, remuneração superior, em seu valor bruto, ao limite estabelecido para a remuneração de servidores do Poder Executivo Federal ( $\mathrm{R} \$ 37.476,93)$ e devem respeitar os valores praticados no mercado de trabalho da região de atuação da entidade (Brasil, 2002b; STF, 2015). Para as OSFL CEBAS, o valor atribuído à remuneração do dirigente precisa respeitar o valor de $70 \%$ (setenta por cento) do limite estabelecido para a remuneração dos servidores do Poder Executivo Federal. Atualmente a maior remuneração praticada para os servidores públicos federal é de aproximadamente $\mathrm{R} \$ 38$ mil. A remuneração dos dirigentes, portanto, deve ser inferior a $\mathrm{R} \$$ 26 mil, aproximadamente. (Brasil, 2013; STF, 2015). 
Outra questão se deve ao fato de que com a necessidade de atrair profissionais de qualidade, normalmente, quando os dirigentes recebem remuneração, mesmo com responsabilidades complexas, o valor tende a ser menor que em organizações com fins lucrativos (Chen, Ren, \& Knoke, 2014; Handy, Mook, Ginieniewicz, \& Quarter, 2007; Leete, 2006; Preyra \& Pink, 2001; Roomkin, 1999).

Uma explicação adicional para a redução nos valores pagos para dirigentes de OSFL é o fato de haver, no setor sem fins lucrativos, muitos empregados voluntários (Mckeever \& Pettijohn, 2014) e pelo fato do objetivo da organização ser em prol da melhoria das condições sociais. Speckbacher (2012) relata que fatores sociais como desejo por aprovação social (ser objeto de admiração de outras pessoas) e desejo de autoaprovação (sentimento de fazer algo bom/merecimento de admiração de outros) também influenciam no comportamento humano e desempenham um importante papel assim como os incentivos implícitos.

Mesmo com o acesso que os doadores possam ter às legislações vigentes, o conhecimento por parte destes das especificidades relacionadas à remuneração de dirigentes de que tratam a lei pode não ocorrer. Assim, mesmo quando não remuneram seus dirigentes, OSFL podem mencionar explicitamente de forma pública (site da organização, relatório de atividades, etc.) que não oferecem qualquer tipo de recompensa financeira aos dirigentes. Neste sentido, os doadores externos podem ser motivados pela divulgação da remuneração do dirigente da OSFL (Andreoni, 1990).

Diversos estudiosos relatam que discussão sobre a remuneração de dirigentes no setor sem fins lucrativos provém do conflito que pressupõe a teoria da agência - assimetria informacional entre dirigentes e stakeholders (Ballantine et al., 2008; Ben-Ner et al., 2010; Gray \& Benson, 2003; Miller, 2002; Olson, 2000). Altos valores de remuneração do dirigente podem ser vistos como violação à restrição de não distribuição de superávit pela OSFL e doadores reconsideram suas doações quando percebem essa prática (Emerson, 2010). O efeito adverso da alta remuneração ocorre tanto para a organização que necessita da aprovação de seus stakeholders, pois interfere na sua imagem e na manutenção da reputação, como também para o doador, que pode considerar o "brilho" de sua ação ofuscado pela má gestão e utilização dos recursos pela OSFL em prol do dirigente e em detrimento da sociedade. Assim, espera-se que o fator disclosure da remuneração do dirigente da OSFL influencie a tomada de decisão do doador, uma vez que este compreenda que há maior transparência na atuação da organização. Diante disso, enuncia-se as seguintes hipóteses:

H1a: Quanto maior o valor divulgado de remuneração do dirigente da OSFL, menor o volume de doação por parte do doador individual. 
H1b: Quanto maior o valor divulgado de remuneração do dirigente da OSFL, menor a propensão de contribuição futura por parte do doador individual.

\subsection{Influência social}

Uma vez que o doador decide contribuir e que a causa vale a pena, o próximo passo é verificar se uma determinada organização é digna do suporte (Teresa P. Gordon \& Khumawala, 1999) e a reputação organizacional pode favorecer as OSFL quanto a essa decisão do doador.

Após a identificação da causa, os doadores se certificarão de alguma forma de que a OSFL é digna de confiança, é bem administrada e aplica os recursos apropriadamente em prol da causa para a qual atendem. Quando essa confiabilidade na aplicação dos recursos por parte do doador não é possível, provavelmente a doação não se concretizará. (Pereira, 2006).

Cruz (2010, p. 11) apresenta a análise sobre os fatores que motivam o brasileiro a fazer doações. A autora identificou a causa como fator principal. Entretanto, várias organizações podem ter como missão uma mesma causa. Ao decidir para qual OSFL realizar a doação por parte dos indivíduos, os achados da autora também identificaram "[...] que as pessoas preferem contribuir para instituições que mostram transparência em suas ações e na forma como aplicam os recursos captados, que transmitem confiança e credibilidade [...]".

Diante disso, além das informações de desempenho e de alocação de recursos que influenciem a preferência dos investidores sociais, quando a OSFL transmite ao doador confiança e credibilidade, pode-se compreender que isso representa a reputação organizacional construída pela mesma. Assim, ceteris paribus, quanto melhor o conceito da entidade, maior a demanda do doador e, consequentemente, maiores contribuições ocorrerão (Cruz, 2010).

Bromley (2002) descreve a reputação organizacional como uma percepção social comum ou um consenso sobre a organização e sua atuação. Este conceito é mais detalhado por Dowling (2004) ao conceituar reputação como um composto de valores atribuídos (autenticidade corporativa, responsabilidade e integridade, por exemplo). A reputação deve ser construída pela OSFL, e, em se tratando de construir reputação perante o doador individual, a organização será mais bem-sucedida por meio de divulgação de suas ações e de informações relevantes, que remetam aos doadores que a OSFL é efetiva no cumprimento de sua missão. 
Essas informações sobre as ações da OSFL para cumprimento de sua missão podem gerar no doador a percepção dos atributos organizacionais. Estes atributos, que refletem a forma pelo qual os doadores veem a OSFL, constituem a reputação corporativa (Roberts \& Dowling, 2002). Um importante aspecto da reputação corporativa é a credibilidade corporativa, ou seja, "a extensão em que consumidores acreditam que uma empresa faça e entregue produtos que satisfaçam as necessidades e os desejos dos consumidores" (Keller, 2013, p.426).

Uma reputação forte com a comunidade pode ser fator importante para a decisão de doadores e potenciais doadores. As doações refletem a confiança que os doadores têm na organização quanto à reputação de realização dos seus objetivos (Parsons, 2003) e, muitas vezes por eles carecerem de informações, Trussel e Parsons (2007) afirmam que os doadores devem considerar a reputação organizacional como forma de avaliação da qualidade dos produtos e serviços das OSFL.

Trussel e Parsons (2007) desenvolveram um estudo em que uma das variáveis consideradas foi a reputação organizacional, sendo esta medida pela qualidade do serviço oferecido pela OSFL. Segundo os autores, entidades mais conhecidas pelos melhores serviços poderão captar mais recursos. Contudo, quando o doador não é o beneficiário dos serviços ou bens, este não está habilitado ou é pouco habilitado para determinar se a OSFL fez seu trabalho, muito menos se o trabalho foi bem feito (Hansmann, 1987a), e, a partir desta perspectiva, a reputação organizacional se torna mais relevante.

Em resumo, a reputação organizacional está relacionada à imagem da OSFL e, consequentemente, com a aceitação da qualidade dos serviços. A opinião pública quando alinhado a um conceito positivo é fundamental para a legitimidade das organizações (Vieira, 2004). Diante disso, é importante que a OSFL divulgue informações que possam permitir ao doador a percepção de que desempenha seu papel em prol da causa para a qual foi criada e que, de maneira alguma, aplica recursos em benefício individual em detrimento do social.

As OSFL possuem, normalmente, parcerias empresariais que podem trazer benefício à organização. Muitas vezes, as empresas com fins lucrativos buscam apoiar as OSFL com o objetivo de demonstrar aos seus consumidores que possuem valores sociais. Contudo, as OSFL também podem tirar vantagem destas relações com empresas solidárias apoiadoras, não apenas por meio de recebimento de recursos, uma vez que, dependendo do montante doado, estes recursos podem ser restringidos em sua utilização.

Quando a empresa solidária apoiadora for conhecida e for dignamente ética e moral, a OSFL pode divulgar informações sobre a mesma, para que os doadores percebam que a 
organização trabalha de forma efetiva no cumprimento de sua missão de modo que, inclusive, é apoiada por empresas importantes do setor com fins lucrativos. Com isso, podem influenciar a decisão do doador, não apenas em doar, como também em contribuir com um maior volume de recursos e aumentar a propensão deste doador em continuar contribuindo no futuro.

Para que a fonte seja bem-sucedida em influenciar o alvo, ela deve ser digna de crédito. Uma fonte com boas credenciais consiste na melhor alternativa para que alcance o crédito estimado do alvo (Davidoff, 2006). Assim, quando a OSFL divulga a empresa solidária apoiadora, esta pode gerar a influência social sobre o doador. De acordo com a Psicologia Social, em relação à influência social da fonte sobre o alvo, para que a mudança de atitude seja caracterizada, esta relação deverá resultar em mudança nas crenças e atitudes do alvo em relação a determinado assunto, o que consiste em um efeito comum da influência social. Além disso, é mais provável conseguir uma mudança de atitude quando as informações apresentadas pela fonte partem de uma figura de autoridade e se baseia na legitimação (Michener, 2005).

Michener (2005, p.38) define a influência social como o que acontece quando ocorre a mudança de opinião do indivíduo, ou este "execute uma ação que, de outro modo, não executaria". Na influência social existe de um lado uma "fonte", de onde parte a influência, e de outro um "alvo", que será submetido à influência proveniente da fonte.

Psicólogos sociais distinguem em dois tipos de influência social: (1) influência social informacional e (2) influência social normativa (Turner \& Oakes, 1986). Segundo a conceituação de Deutsch e Gerard (1955), a primeira representa a aceitação de respostas (crenças, opiniões, atitudes, etc.) como evidência sobre a realidade e que leva à mudança de atitude privada. A segunda é definida como conformidade às expectativas positivas de outros, fundamentada no desejo de aprovação social e para evitar rejeição.

A presente pesquisa tem direcionamento para o primeiro tipo de influência social (informacional), tendo como base o exposto por Turner e Oakes (1986), que descrevem que o processo de influência informacional reflete a dependência em outros para a redução de incerteza. Assim, é considerada como true influence, levando à aceitação privada (mudança genuína nas atitudes e opiniões, a fim de ser correto e, não simplesmente seguir um determinado grupo sem convicção para evitar sanções ou ridicularização, como ocorre na influência normativa).

A teoria da influência social informacional pode ser resumida em três estágios. No primeiro, assume-se que a incerteza subjetiva (lacuna de confiança na validade objetiva da crença, opinião e atitudes do sujeito) é produzida por uma interação não social entre o aparato 
perceptual do apreensor e as características objetivas do estímulo do mundo. Portanto, quanto mais objetivamente ambíguo, complexo, problemático e desestruturado o estímulo do campo, maior a incerteza do indivíduo e a necessidade de informação para reduzi-la. No caso dos doadores individuais, quando não são beneficiários dos serviços prestados e não possuem autonomia para restringir o uso do recurso doado pela OSFL, esta lacuna de confiança ocorre mais facilmente.

No segundo estágio da teoria da influência informacional, compreende-se que a necessidade para reduzir incerteza em uma dada situação conduz à dependência informacional sobre outros (dependência social). Neste ponto, o papel das OSFL em divulgar informações sobre empresas solidárias apoiadoras, que sejam conhecidas e dignas ética e moralmente, é primordial para a redução da incerteza informacional do doador, visto que o mesmo pode perceber a OSFL como monitorada por elas.

Por fim, no terceiro estágio, a dependência informacional conduz à aceitação de influência de outros e, assim, movimenta o sujeito à conformidade a outros, até o nível em que o discurso destes é percebido como provedor de evidência sobre uma realidade objetiva (Turner \& Oakes, 1986). Cialdini e Trost (1998) referem-se a essa forma particular de resposta em consentimento com a OSFL como compliance, e esclarecem que, quando existe um pedido formal direto do solicitante, como ocorre em pedidos de doação por OSFL, o compliance é determinado como explícito. O compliance ocorre, portanto, quando o doador é incentivado a responder de um modo desejado, neste caso com maior volume de contribuição e maior propensão de doar futuramente devido à confiança na OSFL percebida pela empresa solidária apoiadora.

De forma geral, no contexto das OSFL, os doadores individuais possuem maior restrição tanto em relação ao custo de obterem as informações de desempenho da organização, quanto em restringir a doação para ser utilizada pela OSFL em um determinado objetivo (Balsam \& Harris, 2014). Desse modo, para reduzir a incerteza sobre a reputação da OSFL, a busca por informações alternativas da organização por parte do doador tende a ser direcionada para outras formas de informação.

Para as OSFL, tendo como foco o doador individual, a atividade de captação de recursos tem papel similar à propaganda (Weisbrod \& Dominguez, 1986). Uma vez que Jin e Yeo (2011) destacam a confiança conforme o grau em que o público percebe as afirmações feitas por um comunicador como válidas, uma empresa socialmente conhecida e dignamente ética e moral pode gerar compliance no doador para o pedido da OSFL. Assim, a influência por meio da empresa solidária apoiadora pode ajudar em: 
(1) "Marketização" do setor sem fins lucrativos que é caracterizado pela competição pelos doadores e subvenções (Weerawardena \& Mort, 2008);

(2) atividades de marketing para melhorar o posicionamento competitivo de OSFL sobre os recursos dos doadores e retenção de pessoal desempenhar um papel maior do que nunca (Hume \& Hume, 2008)

A ideia concebida pela influência social informacional não é a de que a informação se autovalida, ou seja, o valor informacional de um discurso não é o seu conteúdo informacional direto, mas o grau em que este conteúdo é percebido para prover evidência sobre seus atributos para a realidade.

Como a subjetividade está incluída no processo de avaliação, conexões empresariais relevantes podem refletir mais laços sociais formais e informais e um maior nível de legitimidade, capacidade e status social. Espera-se que as OSFL que divulgam empresas solidárias apoiadoras dignas na ética e na moral, influenciem positivamente no volume de contribuição e na propensão dos doadores individuais em contribuir futuramente. Evidenciase, portanto, as seguintes hipóteses:

H2a: OSFL que divulgam a informação sobre a empresa solidária apoiadora recebem maior volume de doação pelo doador individual do que OSFL que não divulgam.

H2b: OSFL que divulgam a informação sobre a empresa solidária apoiadora obtém maior propensão de doação futura pelo doador individual do que OSFL que não divulgam.

\subsection{Disclosure interativo de remuneração do dirigente e da empresa solidária apoiadora em OSFL}

Além das hipóteses descritas anteriormente, o estudo também buscou verificar a interação das variáveis independentes "remuneração do dirigente" e "empresa solidária apoiadora" e os efeitos sobre as variáveis dependentes "valor doado" e "probabilidade de doar futuramente.

Devido ao recente advento da Lei n. 12.868/2013, que passa a declarar expressamente a permissão para a remuneração de dirigentes para as OSFL que não possuem titulação de 
OSCIP, ainda não houve a compreensão por parte do doador de que o dirigente possa ser remunerado.

As partes interessadas na gestão das OSFL se apresentam como intolerantes em relação à adoção de recompensas que possam abalar a confiança que lhes é atribuída devido ao seu caráter de dedicação à filantropia e à caridade (McGovern, 1992; O'Connell, 1992). A finalidade pública destas instituições também é apontada por Covington (1994). Trata-se de um determinante no cuidado que se deve tomar ao se definirem estratégias de disclosure em OSFL, considerando o potencial de que maior transparência proporciona maior credibilidade à OSFL pelo doador.

Neste sentido, apesar das argumentações de diversos autores de que maiores valores de remuneração de dirigentes reduzam as contribuições por parte do doador individual, autores como Okten e Weisbrod (2000) e Petrovits, Shakespeare, e Shih (2011) relatam que, quando a OSFL é percebida pelos doadores como monitorada por seus outorgantes e patronos, representados, neste estudo, pela empresa solidária apoiadora, existe um efeito "atrativo" de doações.

Os doadores, na ausência de um padrão de remuneração reconhecido para o que é justo e razoável, necessitam da confiança como componente crítico para suas decisões (Balsam \& Harris, 2014). A percepção deles de que a OSFL desenvolve efetivamente sua missão, pois, caso contrário, a empresa solidária apoiadora não submeteria sua imagem à organização, pode reduzir o efeito adverso de alta remuneração do dirigente, e, além disso, conduzir à assimilação de que ao notificar em conjunto a remuneração do dirigente e a empresa solidária apoiadora, consubstancia-se numa forma de a OSFL demonstrar transparência de suas ações.

Compreende-se que o doador será mais propenso a doar um volume maior de recursos e a continuar contribuindo no futuro para as OSFL que divulgam a empresa solidária apoiadora e a remuneração do dirigente, evidenciando-se as hipóteses H3a e H3b, conforme segue:

H3a: OSFL que divulgam a empresa solidária apoiadora e a remuneração do dirigente recebem um maior volume de doações por parte do doador individual do que OSFL que não divulgam.

H3b: OSFL que divulgam a empresa solidária apoiadora e a remuneração do dirigente obtém maior propensão de doações futuras por parte do doador individual do que OSFL que não divulgam. 


\section{METODOLOGIA}

Neste capítulo são apresentados os procedimentos metodológicos utilizados para o desenvolvimento desta pesquisa, composto pelas variáveis da pesquisa, pelo planejamento da pesquisa, pelo delineamento, aleatorização e procedimentos do experimento, pela descrição da população e amostra, pela descrição da OSFL parceira, e validações.

\subsection{Variáveis da pesquisa}

Quanto às variáveis utilizadas nesta pesquisa, tendo como fundamento o desenvolvimento teórico e consequentemente a condução das hipóteses desenvolvidas, as variáveis independentes, "disclosure" de remuneração e "influência social", e as variáveis dependentes, "doações" e "doações futuras", foram relacionadas aos conceitos teóricos. Esta relação pode ser observada na estrutura para validação preditiva experimental fundamentada no modelo de Libby et al. (2002), conforme Figura 2.

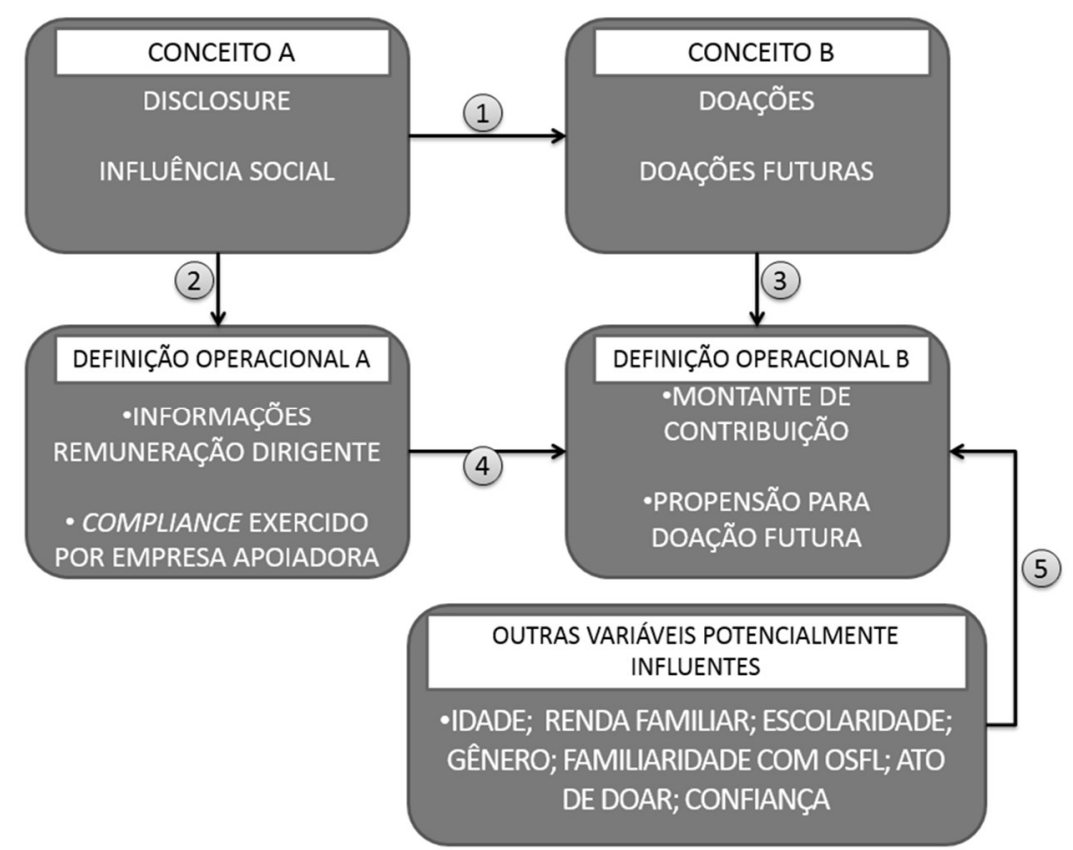

Figura 2 - Estrutura de validação preditiva do experimento Fonte: adaptado de Libby et. al (2002).

Segundo Libby et al. (2002), as hipóteses devem ter validade preditiva. Os conceitos teóricos devem ter relações e devem capturar aspectos importantes do ambiente de destino. As teorias e as hipóteses devem captar a relação entre os elementos do ambiente em estudo. $\mathrm{Na}$ 
Figura 2, observa-se que o link 1 reflete a relação teórica dos elementos estudados, em que as variáveis dependentes, "doações" e "doações futuras" são influenciadas pelas variáveis independentes "disclosure" e "influência social".

Os links 2 e 3 tratam de como o conceito teórico será operacionalizado no experimento. Assim, em relação às variáveis independentes, a variável "disclosure" é operacionalizada por meio de informações sobre a remuneração do dirigente da OSFL e a variável "influência social" é representada pelo compliance exercido por empresa solidária apoiadora conhecida, quando divulgada pela OSFL (informações que não existe obrigatoriedade legal de serem divulgadas pela OSFL). Já a variável dependente "doações" é operacionalizada pelo montante de contribuição do doador individual, e a variável dependente “doações futuras", pela propensão de doações futuras deste, independentemente do valor. O link 4 se refere à relação entre as variáveis independentes e dependentes operacionais, da mesma forma que ocorre na relação conceitual do link 1 .

As variáveis de controle devem ser tratadas de forma que seja possível ao pesquisador isolar o efeito das variáveis relevantes ao estudo. No link 5, portanto, estão identificadas potenciais variáveis que possam influenciar as variáveis dependentes em um ambiente não controlado. O Quadro 6 resume as principais referências que serviram de base para identificação das variáveis de controle.

Quadro 4 - Referências das variáveis de controle

\begin{tabular}{|l|c|}
\hline \multicolumn{1}{|c|}{ Variável de Controle } & Referências \\
\hline Idade & (Idis \& Gallup, 2015; Pharoah \& Tanner, 1997) \\
\hline Gênero & $\begin{array}{c}\text { (Hall, 2004; Idis \& Gallup, 2015; Mesch, } \\
\text { Rooney, Chin, \& Steinberg, 2002) }\end{array}$ \\
\hline Renda Familiar & $\begin{array}{c}\text { (Bryant, Jeon-Slaughter, Kang, \& Tax, 2003; Idis } \\
\text { \& Gallup, 2015; Jones \& Posnett, 1991; } \\
\text { McClelland \& Brooks, 2004) }\end{array}$ \\
\hline Escolaridade & (Idis \& Gallup, 2015) \\
\hline Familiaridade com a OSFL & \begin{tabular}{c} 
(Rodrigues, 2012) \\
\hline Ato de doar
\end{tabular} \\
\hline Confiança & $\begin{array}{c}\text { (Cruz, 2010; Handy et al., 2010; Idis \& Gallup, } \\
\text { 2015; Parsons, 2003; Pereira, 2006; Sargeant et } \\
\text { al., 2006; Tinkelman \& Donabedian, 2007) }\end{array}$ \\
\hline
\end{tabular}

Foram identificadas as seguintes variáveis: Idade; Renda familiar; Escolaridade; Gênero; Familiaridade com OSFL; e Ato de doar (se fez/faz doações, periódicas ou não, tipo de OSFL) e Confiança. 


\subsection{Planejamento da pesquisa}

O objetivo desta pesquisa é identificar se os fatores disclosure de informações de remuneração do dirigente e, influência social (compliance), impacta no montante de contribuição e na propensão de doação futura de doadores individuais para as OSFL. Para a consecução deste objetivo e teste das hipóteses enunciadas no tópico anterior, utilizou-se o método experimental, pois explora os efeitos de variáveis que possam ser manipuladas, buscando a descrição causal concernente a relações bivariadas (Shadish, Cook, \& Campbell, 2002).

Em um experimento, com a manipulação das variáveis é possível ao pesquisador identificar efeitos de forma isolada das demais variáveis estranhas que possam estar presentes em um ambiente não controlado (Libby, Bloomfield, \& Nelson, 2002; Shadish et al., 2002).

Destaca-se que a dificuldade de acesso aos dados de arquivo provenientes das OSFL em seus sites ou para agências de divulgação referentes às variáveis da pesquisa inibe a realização de estudos sobre o tema por meio de utilização de dados teoricamente disponíveis.

\subsection{Delineamento do experimento}

\subsubsection{Tarefa experimental}

Desenvolveu-se uma tarefa experimental com o objetivo de testar as hipóteses enunciadas pela presente pesquisa em relação aos determinantes de doação e doação futura de doadores individuais. Os participantes receberam informações sobre uma OSFL, por meio de uma carta comunicando suas atividades principais e seus projetos desenvolvidos, solicitando contribuições na forma de doação. Salienta-se que o uso de cartas comunicando atributos e projetos desenvolvidos como forma de pedido de contribuições é uma prática comum de OSFL no Brasil.

O conteúdo comunicado na carta de solicitação de contribuição foi manipulado, conforme detalhado no tópico procedimentos experimentais, subtópico aplicação do experimento, com mudanças no valor divulgado da remuneração do dirigente pela OSFL e inclusão de informações sobre a empresa solidária apoiadora à OSFL. 
3.2.1.1 Delineamento do modelo experimental

O experimento ocorreu com a manipulação de dois fatores (nível de remuneração do dirigente e afiliação à empresa solidária apoiadora) no modelo $3 \times 2+1$ between-subjects. A escolha de aplicação between-subjects ocorreu com o objetivo de examinar diferenças entre os indivíduos ou entre os grupos, bem como se elas existem em relação às variáveis dependentes. Nesta forma, cada sujeito é exposto somente a uma das condições por um mesmo período de tempo. A vantagem desta técnica é que eventuais inconsistências ou variações não esperadas sejam compensadas entre os sujeitos, pois os achados expressam resultados independentes de variações dos indivíduos (Sampaio et. al, 2008).

O experimento conta com sete condições possíveis, sendo uma condição de controle em que não houve nenhum tratamento e seis condições experimentais que incluem as variáveis dependentes e independentes desta pesquisa. Optou-se pelo desenho experimental em consonância com a matriz de Kerlinger (1979), conforme Quadro 5:

Quadro 5 - Matriz das condições de controle e experimentais

\begin{tabular}{|c|c|c|c|c|}
\hline & $\begin{array}{l}\text { Não divulga } \\
\text { remuneração } \\
\text { A }\end{array}$ & $\begin{array}{c}\text { Divulga } \\
\text { remuneração baixa } \\
\text { B }\end{array}$ & $\begin{array}{c}\text { Divulga remuneração } \\
\text { moderada } \\
\text { C }\end{array}$ & $\begin{array}{c}\text { Divulga } \\
\text { remuneração alta } \\
\text { D }\end{array}$ \\
\hline $\begin{array}{l}\text { Divulga } \\
\text { Apoiador }\end{array}$ & - & $\begin{array}{c}\text { CASO } 2 \\
(B+1)\end{array}$ & $\begin{array}{c}\text { CASO } 4 \\
(C+1)\end{array}$ & $\begin{array}{c}\text { CASO } 6 \\
(D+1)\end{array}$ \\
\hline $\begin{array}{l}\text { Não divulga } \\
\text { apoiador }\end{array}$ & $\begin{array}{c}\text { CASO } 1 \\
(A+2)\end{array}$ & $\begin{array}{c}\text { CASO } 3 \\
(B+2)\end{array}$ & $\begin{array}{c}\text { CASO } 5 \\
(C+2)\end{array}$ & $\begin{array}{c}\text { CASO } 7 \\
(D+2)\end{array}$ \\
\hline
\end{tabular}

Fonte: adaptado de Kerlinger (1979)

Segundo a matriz das condições de controle e experimentais descrita no Quadro 5, a condição de controle corresponde ao caso 1 e as condições experimentais correspondem aos casos 2, 3, 4, 5, 6 e 7. Assim, os casos foram construídos para que contemplassem todas as variáveis independentes:

- Caso $1(\mathrm{~A}+2)$ - grupo de controle: OSFL que NÃO divulga remuneração e NÃO divulga empresa solidária apoiadora;

- Caso $2(\mathrm{~B}+1)$ : OSFL que divulga remuneração BAIXA e DIVULGA empresa solidária apoiadora;

- Caso $3(\mathrm{~B}+2)$ : OSFL que divulga remuneração BAIXA e NÃO divulga empresa solidária apoiadora;

- Caso $4(\mathrm{C}+1)$ : OSFL que divulga remuneração MODERADA e DIVULGA empresa solidária apoiadora; 
- Caso $5(\mathrm{C}+2)$ : OSFL que divulga remuneração MODERADA e NÃO divulga empresa solidária apoiadora;

- Caso $6(\mathrm{D}+1)$ : OSFL que divulga remuneração ALTA e DIVULGA empresa solidária apoiadora;

- Caso 7 (D+2): OSFL que divulga remuneração ALTA e NÃO divulga empresa solidária apoiadora.

\subsection{Aleatorização do experimento}

Para que o instrumento pudesse ser aplicado, realizou-se a aleatorização por meio da ferramenta do Excel “ALEATÓRIOENTRE”, com números de 1 (um) a 7 (sete), visto as sete condições experimentais. A aleatorização foi restrita, mantendo a homogeneidade da amostra, para que não houvesse quantidades diferentes de condições experimentais e considerando a quantidade inferior a 200 respondentes, conforme sugerido por Shadish et al. (2002). Com isso, é possível realizar a comparação entre os casos e evitar problemas de análise da homogeneidade da variância.

Com o objetivo de facilitar a manipulação dos casos e para que os participantes não tivessem conhecimento, durante a aplicação do experimento, que havia casos distintos, os envelopes foram colocados, previamente, em ordem, conforme a aleatorização e, distribuídos na sala de aplicação do experimento, sempre iniciando da direita para a esquerda.

\subsection{Procedimentos experimentais}

O experimento foi desenvolvido em condições de laboratório, sendo realizado em papel, nas salas de aulas dos alunos. Com base no pré-teste realizado, o tempo estipulado de aplicação do experimento foi de 15 minutos para cada sessão realizada, sendo que em todas foram distribuídos aleatoriamente os casos para os alunos, havendo números equivalentes dos casos distribuídos. O experimento foi aplicado em dois dias, ao total foram cinco sessões para coleta dos dados, cada sessão era composta por uma turma, conforme detalhamento do Quadro 7.

Quadro 6 - Detalhamento das sessões

\begin{tabular}{|c|c|c|c|}
\hline Número da Sessão & Data da Sessão & Número de Participantes & Quantidade de não-aceite \\
\hline 1 & $12 / 11 / 2016$ & 33 & 1 \\
\hline 2 & $12 / 11 / 2016$ & 30 & 2 \\
\hline
\end{tabular}




\begin{tabular}{|l|l|l|l|}
\hline 3 & $12 / 11 / 2016$ & 25 & 0 \\
\hline 4 & $19 / 11 / 2016$ & 29 & 1 \\
\hline 5 & $19 / 11 / 2016$ & 23 & 0 \\
\hline
\end{tabular}

No dia 12/11/2016 foram realizadas três sessões e no dia 19/11/2016 duas. No total, quatro respondentes não aceitaram participar do estudo após a leitura das instruções e do termo de consentimento livre e esclarecido e não houve desistências no decorrer do processo.

\subsubsection{Aplicação do experimento}

Inicialmente, o experimentador apresentou o estudo, de forma padronizada, conforme roteiro de aplicação (Apêndice 7). Na sequência, foram entregues as instruções detalhadas por escrito, para que não houvesse diferença nas informações recebidas nos diversos grupos, detalhado no Apêndice 1, bem como o termo de consentimento livre e esclarecido (TCLE) conforme Apêndice 5.

A leitura das instruções foi feita em voz alta pelo experimentador, e solicitou-se que os participantes realizassem a leitura do termo de consentimento, assinando-o. Após o preenchimento do termo de consentimento, este foi recolhido juntamente com as instruções para o estudo.

Aos respondentes que aceitaram realizar o estudo, o experimentador entregou o primeiro envelope e explicou as ações a serem tomadas aos participantes, bem como sanou eventuais dúvidas e alertou sobre o tempo máximo (04 minutos) para devolução do envelope com a resposta.

Nesta etapa, em relação às variáveis dependentes (doação e doação futura), a tarefa atribuída aos sujeitos consistiu em decidir sobre o montante de doação que gostariam de contribuir e a probabilidade de realizar doações futuras para a OSFL. Para a decisão sobre a variável doação, cada participante recebeu um crédito em dinheiro, no valor de dez reais, e informado que poderia optar por doar integralmente, parcialmente ou não doar para a OSFL, o valor não doado ficaria com o participante. Esta era uma questão aberta que poderia ter como resposta qualquer valor entre zero a dez reais.

O valor correspondente aos dez reais foi definido a partir da renda individual do doador no Brasil, conforme perfil traçado pela pesquisa Doação Brasil em 2015 (IDIS \& Gallup, 2015). Neste perfil, o doador brasileiro foi definido com renda individual a quatro salários mínimos, ou seja, superior a R\$ 3.520 em 2016, quando foi aplicado o experimento. Considerando que a maioria dos trabalhadores no país tem como padrão 22 dias em média de 
trabalho por mês, e 8 horas de trabalho diários, verificou-se que o valor por hora equivale a $\mathrm{R} \$ 20$ (R\$ 5 por 15 minutos). Uma vez que o valor de $\mathrm{R} \$ 5$ por 15 minutos corresponde à faixa salarial mínima do doador no Brasil, para fins de remuneração, considerou-se o valor de dez reais para quinze minutos (tempo de aplicação do experimento), portanto, o dobro do valor equivalente ao tempo de trabalho em relação a renda mínima.

Quando questionados sobre a variável doação futura, a resposta estava organizada em uma escala likert, com sete opções, variando de $0 \%$ a 100\%, para indicar sua pretensão de doação futura, independente do valor.

As decisões dos participantes era consubstanciada pela carta recebida no envelope, com informações da OSFL, informações sobre a remuneração do dirigente (sem informação da remuneração/ remuneração baixa [R 2.000 por mês]/ remuneração moderada [R $\$ 5.000$ por mês]/ remuneração alta [R 8.000 por mês]) e informação da empresa solidária apoiadora (sem informação/ com informação [nome, breve descritivo]). Cada caso possível é detalhado no Apêndice 2.

Visto que a divulgação de informações sobre a remuneração de dirigentes não é obrigatória no Brasil, a determinação dos valores correspondentes à remuneração do dirigente da OSFL foi definida por meio de uma combinação de três informações. Primeiro, verificouse, juntamente com a dirigente da OSFL parceira deste estudo, o valor médio percebido de remuneração de dirigentes de OSFL (R\$3.000).

Segundo, devido à ausência de dados sobre a remuneração média de dirigentes de OSFL no Brasil, verificou-se o salário médio de dirigentes do Serviço Público Municipal (pequeno porte) no Brasil ( $\mathrm{R} \$ 5.000$ aproximadamente), devido à maior proximidade com as características de organizações sem fins lucrativos.

Terceiro, considera-se que, normalmente, para que um profissional assuma um cargo de diretoria, este necessita formação superior e experiência de mercado. Como não é possível atribuir valor para experiência, utilizou-se como equivalente o executivo possuir uma pósgraduação. Portanto, verificou-se o salário médio de executivos com pós-graduação (R\$ 10.000 aproximadamente) no Brasil.

Diante disso, para definição dos valores correspondentes à remuneração do dirigente da OSFL (baixo/médio/alto), optou-se por manter o valor médio correspondente à remuneração média de dirigentes do Serviço Público Municipal (pequeno porte) no Brasil, definido como R\$ 5.000; o valor baixo inferior à média percebida de remuneração de dirigentes de OSFL, definido como R 2.000 ; e o valor alto seguindo a mesma proporção de diferença entre o valor médio e baixo, definido como $\mathrm{R} \$ 8.000$. 
Após o recolhimento dos envelopes da primeira etapa, foram distribuídos envelopes identificados como ETAPA 2, contendo as questões que visam identificar se as pessoas entenderam o que foi perguntado no experimento, denominado de manipulation check, questões pós-experimentais, com o objetivo de controlar as manipulações, e questões demográficas, conforme Apêndice 3. O tempo máximo de resposta nesta etapa foi determinado para 06 minutos.

As perguntas realizadas aos participantes do experimento de manipulation check têm como fim obter respostas com base nas informações recebidas pelos mesmos sobre a OSFL parceira. A primeira questão busca identificar como o respondente avalia o valor divulgado de remuneração do dirigente da OSFL. Esta questão possibilita as respostas: extremamente baixa, baixa, moderada, alta, extremamente alta e não lembro/não vi.

A segunda questão tem como objetivo identificar os três fatores que mais influenciaram a escolha do valor doado pelo participante. Nesta, a resposta foi aberta com possibilidade de indicar até três itens por ordem de importância. Optou-se por resposta aberta para evitar influenciar o participante.

A etapa com as questões pós-experimentais busca informações sobre as variáveis: familiaridade com a OSFL; ato de doar; e confiança. As questões 3, 4 e 6 (Apêndice 3) referem-se à primeira variável. A questão três aborda o conhecimento sobre a OSFL parceira antes de participar deste estudo; a questão quatro verifica se o participante ou algum conhecido é/foi atendido pela instituição; e a questão seis se o participante ou algum conhecido trabalha(ou) em alguma OSFL. Conhecer a OSFL, ter sido atendido ou ter conhecidos que são ou já foram beneficiados pela mesma, ou mesmo se o participante ou algum conhecido trabalha ou trabalhou em OSFL faz com que o indivíduo esteja mais familiarizado com a organização e, desta forma, sinta maior confiança para doar um volume maior de recursos (Sargeant et al., 2006).

A variável ato de doar pode ser verificada na questão cinco (Apêndice 3), que objetiva detectar se o participante já realizou algum tipo de doação ou se o mesmo possui conhecimento de alguém que já doou, a periodicidade da doação, e o tipo de organização, neste se incluiu como opção: laica, religiosa, a OSFL parceira e outros. Optou-se por estes tipos de organizações, pois no Brasil, a influência religiosa é bastante relevante e, ter realizado doações religiosas ou possuir o hábito de realizar doações periódicas influenciam na decisão de contribuir para OSFL (IDIS \& Gallup, 2015; Rodrigues, 2012; Sargeant et al., 2006). 
Na questão sete (Apêndice 3), questiona-se qual o nível de confiança do participante em relação à OSFL, tendo como base as informações que foram apresentadas da organização. Esta questão é proveniente do estudo de Sargeant et al. (2006) e foi apresentada em forma de afirmações, e cada uma destas com possibilidade de resposta entre cinco opções (escala likert): discordo fortemente; discordo parcialmente; nem concordo, nem discordo; concordo parcialmente; concordo fortemente.

Sargeant et al. (2006) detalha que a confiança dos doadores na OSFL ocorre com base na sua percepção sobre os impactos dos benefícios prestados à sociedade e sobre a gestão de desempenho informados pela instituição. A manutenção das doações também está estreitamente relacionada com a confiança, como afirma a pesquisa Doação Brasil, em que verificaram que entre as principais razões para o indivíduo não doar ou deixar de realizar doações é a falta de confiança na OSFL (IDIS \& Gallup, 2015).

A última parte contempla as questões demográficas que buscam caracterizar a amostra selecionada para o experimento. Esta etapa contempla apenas uma pergunta sobre a renda familiar. As demais variáveis, gênero, idade e formação, foram obtidas do formulário de matrícula no curso de especialização em que os participantes estão vinculados, com a devida autorização dos coordenadores dos cursos.

Após o término do questionário, os participantes que não doaram o total do valor do crédito à AFECE receberam o valor correspondente em envelope codificado, mediante assinatura de recibo, conforme Apêndice 8. Além disso, os sujeitos deixaram o e-mail em lista (Apêndice 4) se desejassem receber um resumo com o objetivo da pesquisa e os principais resultados. Ao final, os participantes receberam uma carta de esclarecimento de informações (Apêndice 6), que a remuneração atribuída ao dirigente da AFECE não era verídica.

\subsection{População e amostra}

Os sujeitos da pesquisa são alunos de pós-graduação lato sensu em Contabilidade da Universidade Federal do Paraná (UFPR) que foram participaram de casos hipotéticos de solicitações de recursos feita pela OSFL parceira desse estudo. Apesar de ser pós-graduação em contabilidade, os alunos podem cursar a especialização, independente da área de formação.

A amostra correspondente à população de doadores foi direcionada a potenciais doadores e sua seleção foi do tipo intencional, devido a pesquisa Doação Brasil (IDIS \& Gallup, 2015), que define o perfil do doador brasileiro quanto ao nível de instrução como 
indivíduos com formação superior. Considerou-se que participantes com formação relacionada à área de negócios estariam mais propensos a considerarem informações financeiras, como a remuneração do dirigente, em suas decisões de doação. Além disso, a amostra é considerada passível de ser proxy para doadores individuais, pois em análise descritiva dos respondentes se verificou que $71,4 \%$ responderam que fazem doações para OSFL.

\subsection{OSFL parceira}

O experimento foi desenvolvido buscando manter os casos o mais próximo possível da realidade. Para isso, foi necessário buscar uma OSFL parceira que não fosse amplamente conhecida e que, ao mesmo tempo, recebesse o apoio solidário de, pelo menos, uma empresa conhecida. Essa característica referente à OSFL parceira foi relevante para que o controle em relação ao compliance pudesse ocorrer.

A organização que aceitou a parceria foi a Associação Franciscana de Educação ao Cidadão Especial (AFECE). Esta organização é do terceiro setor, não possui finalidade econômica e atua na área de educação especial, atendendo mais de 225 pessoas com deficiência intelectual de alta especificidade associada ou não a outras patologias, de ambos os sexos em situação de fragilidade decorrente da pobreza, ausência de renda, acesso precário ou nulo aos serviços públicos ou fragilização de vínculos afetivos procedente de Curitiba e Região Metropolitana.

\subsubsection{Empresa solidária apoiadora da OSFL parceira (AFECE)}

A AFECE possui várias empresas solidárias apoiadoras: Acom Sistemas, COPEL, Sanepar, Itaú, Lojas Renner, UNIMED Curitiba, O Boticário, Potencial Petróleo, Volvo, Vale Fértil, Opus Múltipla, Perfipar, Divesa, Ministério do Trabalho, Mondelez, Spaipa, entre outros.

Optou-se, para divulgação no experimento, pela empresa O Boticário. A opção por essa empresa se deu pela mesma ser uma empresa do município de realização da pesquisa, ter sido premiada como melhor franquia de 2016; a melhor empresa para se trabalhar nos anos de 2014, 2015 e 2016; e por ter sido considerada a empresa mais inovadora no Brasil em 2014. Desta forma, ampliam-se as chances de o respondente do experimento conhecer a empresa $\mathrm{O}$ Boticário. 
Além disso, algumas empresas embora conhecidas, não foram selecionadas, pois, se buscou reduzir a possibilidade de inversão de valores. Pode-se citar como exemplos a Volvo, que produz veículos que emitem poluentes para a atmosfera e, a Spaipa, que possui produtos considerados por especialistas não benéficos à saúde.

\subsection{Pré-teste do questionário utilizado no experimento}

Adicionalmente à forma de delineamento do experimento, que buscou aumentar a validade interna (between-subjects; aleatorização), o instrumento de coleta de dados passou por validação em três instâncias: (1) validação dos construtos; (2) validação do instrumento de coleta - validade aparente; (3) pré-teste antes da aplicação do experimento com os respondentes.

Para validar os construtos do experimento, este foi submetido para análise com docentes e/ou doutorandos da Universidade Federal do Paraná (UFPR), com o objetivo de validar os construtos do instrumento de coleta. Nesta etapa, o pesquisador explica o objetivo da pesquisa e solicita que os docentes/doutorandos analisem se o instrumento (experimento) é válido para responder ao problema elucidado nesta pesquisa e está alinhado às hipóteses enunciadas. Participaram dessa etapa dois docentes e dois doutorandos.

A segunda validação do experimento foi realizada com alunos estudantes de pósgraduação stricto sensu da UFPR, em nível de mestrado, para fins de ajustes e verificação possíveis de problemas na coleta de dados. O objetivo desta etapa é a validação aparente do instrumento de coleta de dados e se os participantes compreendem as questões do mesmo. Participaram dessa etapa três mestrandos.

Por fim, após os ajustes referentes à validação de construto e à validação das características textuais, realizou-se o pré-teste com alunos do último período da graduação em Ciências Contábeis da UFPR. O pré-teste teve como objetivo identificar o tempo total necessário para aplicação do experimento e a necessidade de ajustes adicionais a serem realizados antes da aplicação do mesmo, com os reais respondentes. Entende-se que, como a aplicação do experimento teve como participantes alunos de especialização, estes tendem a utilizar menos tempo e a compreender mais facilmente as questões em relação aos alunos em nível de graduação.

As validações do constructo, aparente e pré-teste desta pesquisa foram realizadas em etapas, conforme a Figura 3. 


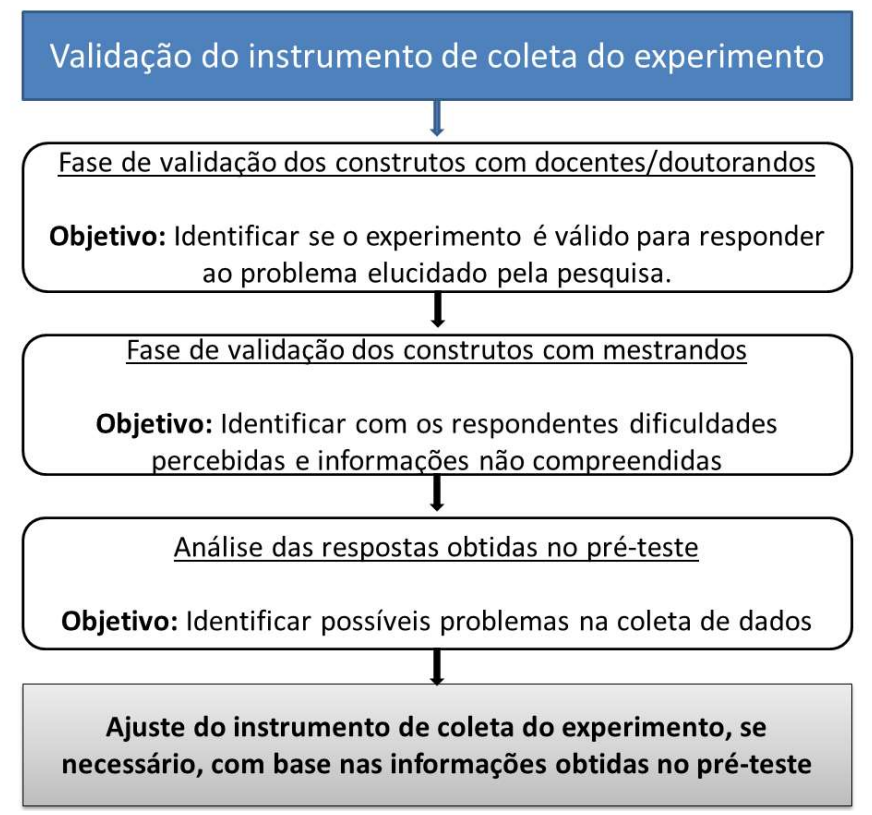

Figura 3 - Validação do instrumento de coleta do experimento

\subsection{Tratamento estatístico para análise dos dados}

Após a tabulação dos dados e codificação, realizaram-se os ajustes à base para que as análises fossem viabilizadas, conforme tópico 4.1. Concretizou-se, na sequência, a estatística descritiva para representar a amostra e revisar os dados, verificando se havia falha na tabulação dos mesmos ou erro, descrita no tópico 4.2.

Realizou-se a análise de manipulation check para verificar se as manipulações foram eficazes, conforme tópico 4.3. A análise de diagnóstico ocorreu por meio de correlações com as variáveis de controle pelas técnicas do Coeficiente de Spearman para a variável "valor doado" (escalar) e do teste Qui-quadrado para a variável "probabilidade de doar futuramente" (ordinal), detalhado no item 4.4 .

Para verificar a normalidade dos dados, aplicou-se a análise de Kolmogorov-Smirnov (KS), com o objetivo de verificar se a técnica de análise seria paramétrica ou não paramétrica. Constatou-se que os dados não possuem distribuição normal, portanto, para análise da variável "valor doado", o teste de média foi realizado pelo método estatístico Kruskal Wallis (KW) e U de Mann Whitney (MW) e, para a variável "probabilidade de doar futuramente", o teste Qui-quadrado, descritos no item 4.5. Completou-se a análise dos dados por meio de correlações e testes de média adicionais para ampliar o detalhamento dos resultados, descrito no tópico 4.6 e de moderação das variáveis de confiança conforme item 4.7. Todos os testes de significância realizados foram bicaudais. 


\section{ANÁLISE DOS RESULTADOS}

\subsection{Ajustes à base de dados}

Depois de tabulados os dados e codificados, adicionou-se uma coluna correspondente ao percentual doado (valores relativos) em relação ao que foi respondido de valor doado, denominada "grupo de divulgação", que corresponde à classificação (1 a 7) em conformidade com o grupo condicional. Esta classificação foi definida conforme abaixo:

Quadro 7 - Agrupamento de "grupo de divulgação"

\begin{tabular}{|c|c|l|}
\hline Grupos & Grupo de "divulgação" & \multicolumn{1}{|c|}{ Definição da remuneração } \\
\hline 1 & OSFL NÃO DIVULGADORA_1 & Sem informação de remuneração \\
\hline 2 & OSFL NÃO DIVULGADORA_2 & Com remuneração baixa (R\$ 2000) \\
\hline 3 & OSFL NÃO DIVULGADORA_3 & Com remuneração moderada (R\$ 5000) \\
\hline 4 & OSFL NÃO DIVULGADORA_4 & Com remuneração alta (R\$ 8000) \\
\hline 5 & OSFL DIVULGADORA_1 & Com remuneração baixa $(\mathrm{R} \$ 2000)$ \\
\hline 6 & OSFL DIVULGADORA_2 & Com remuneração moderada $(\mathrm{R} \$ 5000)$ \\
\hline 7 & OSFL DIVULGADORA_3 & Com remuneração alta $(\mathrm{R} \$ 8000)$ \\
\hline
\end{tabular}

O Rótulo de Grupo de "remuneração" foi inicialmente dividido em "OSFL NÃO DIVULGADORA" para os grupos que não receberam a informação da empresa solidária apoiadora (O Boticário) e em "OSFL DIVULGADORA" para os grupos que receberam a informação da empresa solidária apoiadora (O Boticário). Os números de 1, 2, 3 e 4 correspondem a grupos que "não receberam a informação de remuneração", "receberam informação de remuneração baixa (R 2.000$)$ ", "receberam informação de remuneração moderada (R \$5.000)" e "receberam informação de remuneração alta (R \$8.000)", respectivamente.

Para a questão sobre os três principais fatores que motivaram a decisão do doador (questão 2 - Manipulation Check - Apêndice 3), optou-se por classificar as respostas em 7 categorias: (1) relacionado à instituição; (2) relacionado ao valor/dinheiro recebido; (3) relacionado à responsabilidade social; (4) relacionado à pesquisa; (5) relacionado aos interesses próprios; (6) relacionado ao disclosure; (7) relacionado à propensão de não doar. As respostas originais e, para qual grupo foram categorizadas, podem ser observadas no Apêndice 9.

Realizou-se, também, a Análise Fatorial para as respostas correspondentes às questões de confiança: "confiança na causa”, "confiança ética", "confiança uso recursos”, "confiança 
não tira vantagem", "confiança técnicas respeitosas", correspondentes à questão validada pelo estudo de Sargeant et al. (2006), para verificar se estão correlacionadas. A Análise Fatorial pretende analisar um conjunto de variáveis e agrupá-las em fatores, ou seja, em grupos formados por um conjunto de variáveis que apresentam forte correlação.

A Análise Fatorial exploratória ocorreu por meio do teste de Kaiser-Meyer-Olkyn (KMO), obtendo-se resultado significativo de 0,882. A análise resultou em um fator explicando $76,73 \%$ da variância dos dados originais. O fator inclui as seguintes variáveis: "confiança ética", "confiança uso recursos", "confiança não tira vantagem”, "confiança técnicas respeitosas". Estas variáveis correspondentes ao fator foram agrupadas em uma nova variável com o somatório das respostas, denominada "Confiança Total".

\subsection{Estatística descritiva dos dados}

Efetuaram-se análise descritiva das frequências (variáveis nominais e ordinais) e análise de múltipla resposta para a questão "tipo de OSFL que doa/doou".

Foram realizadas cinco sessões conforme descrito no Quadro 9, com um total de 33, 30, 25, 29 e 23 respondentes nas sessões 1, 2, 3, 4 e 5, respectivamente. No total, somam-se 140 participantes.

Quadro 8 - Estatística descritiva - sessão
\begin{tabular}{|c|c|c|c|}
\hline Sessão & Frequência & $\%$ & $\begin{array}{c}\text { \% } \\
\text { Acumulado }\end{array}$ \\
\hline 1 & 33 & 23,6 & 23,6 \\
\hline 2 & 30 & 21,4 & 45,0 \\
\hline 3 & 25 & 17,9 & 62,9 \\
\hline 4 & 29 & 20,7 & 83,6 \\
\hline 5 & 23 & 16,4 & 100,0 \\
\hline Total & 140 & 100,0 & \\
\hline
\end{tabular}

Sobre a formação dos participantes, verifica-se que a maioria $(58,6 \%)$ é formada em Ciências Contábeis, seguido de 20\% formados em Administração, 5,7\% em Ciências Econômicas e 5\% em Direito. As demais áreas de formação juntas totalizam 10,7\% dos respondentes.

Em relação ao gênero, $62,1 \%$ correspondem ao feminino e $37,9 \%$ ao masculino. Ao se constatar a escolaridade, devido ao público alvo da pesquisa, todos os participantes possuem 
ao menos o ensino superior completo. Observou-se que, do total dos respondentes, 13,6\% já concluíram ao menos uma especialização e $4 \%$ possuem mestrado completo.

A remuneração do dirigente foi designada pelo estudo e as quantidades de cada caso controladas na aleatorização, conforme descrito no item 3.3.5. Portanto, houve 20 (14,3\%) respondentes para o caso de controle (sem informação da remuneração) e 40 (28,6\%) respondentes para cada um dos demais níveis de remuneração divulgada.

Da mesma forma, a divulgação empresa solidária apoiadora foi controlada. Houve 80 $(57,1 \%)$ respondentes para casos em que não foi divulgada a empresa solidária apoiadora e 60 (42,9\%) para casos em que a empresa solidária apoiadora foi divulgada pela OSFL.

Em relação ao valor doado, $86,4 \%$ dos respondentes decidiram pela doação do valor total de dez reais, 7,9\% não doaram, 4,3\% contribuíram com a metade do valor ( $\mathrm{R} \$ 5$ reais) e, houve dois respondentes que indicaram como doação $\mathrm{R} \$ 9,90$ e $\mathrm{R} \$ 9,99$, respectivamente.

Para a resposta sobre a probabilidade de doar futuramente para a AFECE, a maioria das respostas $(26,4 \%)$ indicou probabilidade moderada, seguida de alta probabilidade $(17,9 \%)$ e baixa probabilidade $(17,1 \%)$. A resposta referente a nenhuma probabilidade foi marcada por $16,4 \%$ dos participantes; seguida de $10 \%$ para baixíssima probabilidade; $6,4 \%$ para altíssima probabilidade; e, 5,7\% para doação certa.

Quadro 9 - Estatística descritiva da probabilidade de doar futuramente para a AFECE

\begin{tabular}{|l|c|c|c|}
\hline Probabilidade de doar futuramente & Frequência & \% & \% Acumulado \\
\hline Nenhuma probabilidade & 23 & 16,4 & 16,4 \\
\hline Baixíssima probabilidade & 14 & 10,0 & 26,4 \\
\hline Baixa probabilidade & 24 & 17,1 & 43,6 \\
\hline Moderada probabilidade & 37 & 26,4 & 70,0 \\
\hline Alta probabilidade & 25 & 17,9 & 87,9 \\
\hline Altíssima probabilidade & 9 & 6,4 & 94,3 \\
\hline Doação certa & 8 & 5,7 & 100,0 \\
\hline Total & $\mathbf{1 4 0}$ & $\mathbf{1 0 0 , 0}$ & \\
\hline
\end{tabular}

Os respondentes também fizeram a avaliação da remuneração do dirigente conforme a percepção própria. A grande maioria $(51,2 \%)$ indicou que percebeu a remuneração do dirigente como moderada, independentemente do caso recebido e do valor designado pelo estudo. 
Quadro 10 - Estatística descritiva da avaliação da remuneração do dirigente

\begin{tabular}{|l|c|c|c|}
\hline \multicolumn{1}{|c|}{ Avaliação da remuneração do dirigente } & Frequência & \% & \% Acumulado \\
\hline Extremamente baixa & 5 & 3,6 & 3,6 \\
\hline Baixa & 25 & 17,9 & 21,4 \\
\hline Moderada & 65 & 46,4 & 67,9 \\
\hline Alta & 26 & 18,6 & 86,4 \\
\hline Extremamente alta & 6 & 4,3 & 90,7 \\
\hline Não lembro & 13 & 9,3 & 100,0 \\
\hline Total & $\mathbf{1 4 0}$ & $\mathbf{1 0 0 , 0}$ & \\
\hline
\end{tabular}

Sobre os fatores que mais motivaram a decisão dos participantes, o Quadro 12 demonstra que para o $1^{\mathrm{o}}, 2^{\mathrm{o}}$ e $3^{\mathrm{o}}$ fatores mais importantes, aqueles relacionados com a instituição representam $56,4 \%, 44,3 \%$ e $32,9 \%$ das respostas, respectivamente.

Quadro 11 - Estatística descritiva dos fatores que mais motivaram a decisão

\begin{tabular}{|l|c|c|c|c|c|c|}
\multirow{2}{*}{\multicolumn{1}{c}{ DESCRIÇÃO }} & \multicolumn{2}{c|}{ FATOR 1 } & \multicolumn{2}{c|}{ FATOR 2 } & \multicolumn{2}{c|}{ FATOR 3 } \\
\cline { 2 - 7 } & Frequência & $\mathbf{\%}$ & Frequência & \% & Frequência & \% \\
\hline Relacionado à instituição & 79 & 56,4 & 62 & 44,3 & 46 & 32,9 \\
\hline Relacionado ao valor/ dinheiro recebido & 23 & 16,4 & 22 & 15,7 & 21 & 15,0 \\
\hline Relacionado à responsabilidade social & 21 & 15,0 & 30 & 21,4 & 24 & 17,1 \\
\hline Relacionado à pesquisa & 4 & 2,9 & 4 & 2,9 & 9 & 6,4 \\
\hline Relacionado aos interesses próprios & 8 & 5,7 & 6 & 4,3 & 3 & 2,1 \\
\hline Relacionado ao disclosure & 1 & 0,7 & 7 & 5,0 & 9 & 6,4 \\
\hline Relacionado à propensão de não doar & 4 & 2,9 & 1 & 0,7 & 3 & 2,1 \\
\hline Não houve & 0 & 0,0 & 8 & 5,7 & 25 & 17,9 \\
\hline Total & 140 & 100,0 & 140 & 100,0 & 140 & 100,0 \\
\hline
\end{tabular}

$\mathrm{Na}$ questão sobre se o respondente ou algum familiar é/foi atendido pela AFECE, verificou-se que apenas um já foi beneficiário dos serviços da organização.

Questionou-se também se o participante ou alguém da família faz/fez doação para OSFL. Identificou-se que 71,4\% responderam positivamente à questão, e 28,6\% não fazem doação para OSFL.

Para os participantes que fazem doação, questionou-se também se a doação é periódica. Verifica-se que 55,7\% responderam que a doação é periódica; $15,7 \%$ que não é periódica; e 28,6\% correspondem a respondentes que não fazem doação para OSFL.

$\mathrm{Na}$ questão que busca identificar se o respondente trabalha/ou em OSFL, a grande maioria $(70,7 \%)$ não trabalha neste tipo de organização.

Outra questão foi referente ao quanto o participante confiava na AFECE. Essa questão era composta de seis afirmações sobre diferentes parâmetros de confiança, conforme resumo de respostas no Quadro 13. A primeira buscou identificar qual o nível de confiança do participante de que a AFECE atua para o melhor interesse em prol da causa. Houve maior frequência de respostas $(70 \%)$ para afirmações que confirmavam a confiança do respondente na OSFL (concordo fortemente e concordo parcialmente). 
Sobre o nível de confiança de que a AFECE conduz suas operações de maneira ética, confiança de que a AFECE usa apropriadamente os recursos em forma de doação, confiança de que a AFECE não tira vantagem de seus doadores e de que a AFECE é confiável, a maioria das respostas foi "nem discordo, nem concordo", conforme Quadro 13.

Quadro 12 - Estatística descritiva questão Confiança

\begin{tabular}{|l|c|c|c|c|c|c|c|}
\hline \multirow{2}{*}{ QUESTÃo } & F/\% & $\mathbf{1}$ & $\mathbf{2}$ & $\mathbf{3}$ & $\mathbf{4}$ & $\mathbf{5}$ & \multirow{2}{*}{ TOTAL } \\
\hline \multirow{2}{*}{ Confiança causa } & Frequência & 1 & 1 & 40 & 48 & 50 & $\mathbf{1 4 0}$ \\
\hline \multirow{2}{*}{ Confiança ética } & $\%$ & 0,7 &, 7 & 28,6 & 34,3 & 35,7 & $\mathbf{1 0 0 , 0}$ \\
\hline \multirow{2}{*}{ Confiança uso de recursos } & Frequência & 0 & 3 & 60 & 38 & 39 & $\mathbf{1 4 0}$ \\
\cline { 2 - 8 } & $\%$ & 0,0 & 2,1 & 42,9 & 27,1 & 27,9 & $\mathbf{1 0 0}$ \\
\hline \multirow{2}{*}{ Confiança não tira vantagem } & Frequência & 1 & 4 & 69 & 34 & 32 & $\mathbf{1 4 0}$ \\
\cline { 2 - 8 } & Frequência & 0 & 2 & 73 & 25 & 40 & $\mathbf{1 4 0}$ \\
\hline \multirow{2}{*}{ Confiança técnicas angariar recursos } & Frequência & 0 & 1 & 60 & 31 & 48 & $\mathbf{1 4 0}$ \\
\cline { 2 - 8 } & $\%$ & 0,0 &, 7 & 42,9 & 22,1 & 34,3 & $\mathbf{1 0 0 , 0}$ \\
\hline \multirow{2}{*}{ AFECE é confiável } & Frequência & 0 & 2 & 70 & 30 & 38 & $\mathbf{1 4 0}$ \\
\cline { 2 - 8 } & $\%$ & 0,0 & 1,4 & 50,0 & 21,4 & 27,1 & $\mathbf{1 0 0 , 0}$ \\
\hline
\end{tabular}

Legenda: 1 - Discordo fortemente; 2 - Discordo parcialmente; 3 - Nem discordo, nem concordo; 4 - Concordo parcialmente; 5 - Concordo fortemente.

A última questão das variáveis de controle foi sobre a renda familiar em salários mínimos. Mais de $75 \%$ dos respondentes apresenta renda familiar maior que quatro salários mínimos, conforme Quadro 14.

Quadro 13 - Estatística descritiva da Renda Familiar
\begin{tabular}{|l|c|c|c|}
\hline Renda familiar & Frequência & $\%$ & $\begin{array}{c}\% \\
\text { Acumulado }\end{array}$ \\
\hline ATÉ_2_SM & 7 & 5,0 & 5,0 \\
\hline +2_SM_ATÉ_4_SM & 26 & 18,6 & 23,6 \\
\hline +4_SM_ATÉ_10_SM & 66 & 47,1 & 70,7 \\
\hline +10_SM_ATÉ_20_SM & 33 & 23,6 & 94,3 \\
\hline +20_SM & 8 & 5,7 & 100,0 \\
\hline Total & $\mathbf{1 4 0}$ & $\mathbf{1 0 0 , 0}$ & \\
\hline
\end{tabular}

Por fim, realizou-se a análise Multiple Response para as respostas correspondentes à questão "Tipo de OSFL para o qual doa/doou”. A Multiple Response é uma função do SPSS preparada especialmente para lidar com situações de resposta múltipla, ou seja, em situações em que para uma determinada pergunta existe uma lista de atributos e a possibilidade de que mais do que um destes atributos sejam indicados pelo respondente. 
Inicialmente o teste descreve o número de respostas válidas. Do total das 140 respostas, 100 foram consideradas válidas pois são referentes aos indivíduos que, na questão “faz/fez doação para OSFL" responderam "SIM". OS demais totalizaram 40 indivíduos que responderam "NÃO" à questão "faz/fez doação para OSFL" e, portanto, não precisavam responder a questão sobre "Tipo de OSFL para o qual doa/doou".

\begin{tabular}{|c|c|c|}
\hline \multirow{2}{*}{$\begin{array}{c}\text { TIPO OSFL - SIM } \\
\text { (Frequências) }\end{array}$} & \multicolumn{2}{|c|}{ Respostas } \\
\hline & Qtd & $\%$ \\
\hline Laica & 49 & $41,5 \%$ \\
\hline Religiosa & 60 & $50,8 \%$ \\
\hline Afece & 1 &, $8 \%$ \\
\hline Outro-asilo & 4 & $3,4 \%$ \\
\hline Outro-orfanato & 4 & $3,4 \%$ \\
\hline Total & 118 & $100,0 \%$ \\
\hline
\end{tabular}

Percebe-se que a grande maioria efetua doações para OSFL Religiosas, seguidas de OSFL Laicas. O total das respostas foi 118 , pois o indivíduo poderia assinalar mais de uma resposta para esta questão.

Quadro 15 - Frequências de "NÃO" - Tipo de OSFL que faz doações
\begin{tabular}{|l|c|c|}
\hline \multirow{2}{*}{$\begin{array}{c}\text { TIPO OSFL - NÃO } \\
\text { (Frequências) }\end{array}$} & \multicolumn{2}{|c|}{ Respostas } \\
\cline { 2 - 3 } & Qtd & $\mathbf{\%}$ \\
\hline Laica & 51 & $13,4 \%$ \\
\hline Religiosa & 40 & $10,5 \%$ \\
\hline AFECE & 99 & $25,9 \%$ \\
\hline Outro-asilo & 96 & $25,1 \%$ \\
\hline Outro-orfanato & 96 & $25,1 \%$ \\
\hline Total & $\mathbf{3 8 2}$ & $\mathbf{1 0 0 , 0 \%}$ \\
\hline
\end{tabular}

Em relação ao tipo de OSFL para a qual os indivíduos não efetuam doação, verifica-se que a maioria não contribui para a OSFL, parceira do estudo (AFECE), com 99\% dos casos válidos, seguido de asilos e orfanatos.

Observa-se que o objetivo da pesquisa era possuir como parceira uma OSFL que não fosse amplamente conhecida, viabilizando, com isso, a manipulação das variáveis independentes. 


\subsection{Análise de manipulation check}

As variáveis que tinham como objetivo verificar a manipulação realizada no experimento foi a variável "avaliação da remuneração do dirigente", que buscou verificar a percepção do doador em relação ao valor da remuneração do dirigente do caso recebido. Havia seis possibilidades de resposta para esta questão, sendo elas "extremamente baixa", "baixa", "moderada", "alta", "extremamente alta" e "não lembro/não vi”.

Para a remuneração do dirigente, investigou-se a correlação entre o valor recebido pelo participante conforme determinação do estudo (baixa, moderada e alta) com a percepção do doador sobre a remuneração do dirigente. Os resultados foram significativos para a associação entre o valor de remuneração determinado pelo estudo e a percepção do respondente em relação à remuneração do dirigente, conforme Quadro 17, indicando que os sujeitos perceberam e interpretaram corretamente esta variável independente (Libby et al., 2002).

Quadro 16 - Manipulation Check - Remuneração X Percepção da Remuneração

\begin{tabular}{|l|c|c|c|c|c|c|c|}
\hline \multirow{2}{*}{$\begin{array}{l}\text { Remuneração } \\
\text { do dirigente }\end{array}$} & $\begin{array}{c}\text { Extremamente } \\
\text { baixa }\end{array}$ & Baixa & Moderada & Alta & $\begin{array}{c}\text { Extremamente } \\
\text { alta }\end{array}$ & $\begin{array}{c}\text { Não } \\
\text { lembro }\end{array}$ & \begin{tabular}{l} 
Total \\
\cline { 2 - 8 }$n n n$
\end{tabular} \\
\hline Baixa & 4 & 16 & 16 & 2 & 1 & 1 & $\mathbf{4 0}$ \\
\hline Moderada & 1 & 5 & 22 & 11 & 1 & 0 & $\mathbf{4 0}$ \\
\hline Alta & 0 & 2 & 20 & 12 & 4 & 2 & $\mathbf{4 0}$ \\
\hline Total & $\mathbf{5}$ & $\mathbf{2 3}$ & $\mathbf{5 8}$ & $\mathbf{2 5}$ & $\mathbf{6}$ & $\mathbf{3}$ & $\mathbf{1 2 0}$ \\
\hline p-value & $\mathbf{0 , 0 0 0}$ & \multicolumn{5}{|c}{} &
\end{tabular}

\subsection{Análises das variáveis de controle}

As variáveis de controle são as seguintes:
a) Idade
b) Formação
c) Escolaridade
d) Gênero
e) Conhecia a AFECE
f) Foi atendido pela AFECE
g) Faz doações para OSFL
h) Tipo de OSFL que faz doações (laica, religiosa, AFECE, outros)
i) Doação é periódica
j) Trabalhou OSFL
k) Renda Familiar
1) Doação \% IR 
Com o objetivo de verificar se a aleatorização funcionou, analisou-se as diferenças das variáveis de controle em relação às condições experimentais por meio dos testes Kruskal Wallis e Qui-quadrado. Para todas as variáveis de controle não houve resultado significativo: "idade" (qui-quadrado 9,905 e nível de significância 0,129), "formação" (nível de significância 0,748), “escolaridade" (nível de significância 0,321), "gênero" (nível de significância 0,765), "conhecia a AFECE" (nível de significância 0,684), "foi atendido pela AFECE” (nível de significância 0,418), "faz doações para OSFL" (nível de significância 0,772), "tipo de OSFL - laica" (nível de significância 0,800), "tipo de OSFL - religiosa" (nível de significância 0,417), “tipo de OSFL - AFECE” (nível de significância 0,418), "tipo de OSFL - outros" (nível de significância 0,176), "doação periódica" (nível de significância 0,491), "trabalhou em OSFL" (nível de significância 0,855), "renda familiar" (nível de significância 0,869$)$.

\subsection{Análise das hipóteses da pesquisa}

A presente pesquisa objetivou identificar se o disclosure voluntário da remuneração do dirigente e da empresa solidária apoiadora da OSFL possuem efeitos na decisão do volume de contribuição e na propensão de doar futuramente por parte do doador individual. Para consecução do objetivo, apresentaram-se hipóteses que analisaram o efeito principal da remuneração do dirigente, o efeito principal da divulgação da empresa solidária apoiadora e o efeito interativo destas duas variáveis independentes.

\subsubsection{Análise do efeito principal da remuneração}

As hipóteses de pesquisa com as quais se verificou o efeito principal da divulgação da remuneração do dirigente da OSFL sobre a decisão do doador individual são descritas a seguir, com as devidas análises.

H1a: Quanto maior o valor divulgado de remuneração do dirigente da OSFL, menor volume de contribuição por parte do doador individual.

A princípio se realizou o teste $\mathrm{U}$ de Mann Whitney comparativo entre o grupo de controle e os demais grupos para investigar se a divulgação da remuneração do dirigente, independentemente do valor, tem algum efeito no valor doado. Não se encontrou significância 
na análise que indicasse diferença de média do valor doado para quando a OSFL divulga a remuneração do dirigente, visto estatística teste $Z$ igual a $-0,541$ e nível de significância de 0,589 .

Para verificar o efeito principal do montante de remuneração divulgado, para cada "grupo de divulgação" houve reclassificação, conforme segue:

Quadro 17 - Reclassificação de "grupo de divulgação" - efeito da remuneração

\begin{tabular}{|c|c|c|l|}
\hline \multicolumn{4}{|c|}{ EFEITO PRINCIPAL DA REMUNERAÇÃO } \\
\hline Novo código do grupo & Grupos & Grupo de "divulgação" & Definição da remuneração \\
\hline $\mathbf{1}$ & 1 & OSFL NÃO DIVULGADORA_1 & sem informação de remuneração \\
\hline $\mathbf{2}$ & 2 & OSFL NÃO DIVULGADORA_2 & com remuneração baixa (2000) \\
\hline $\mathbf{3}$ & 3 & OSFL NÃO DIVULGADORA_3 & com remuneração moderada (5000) \\
\hline $\mathbf{4}$ & 4 & OSFL NÃO DIVULGADORA_4 & com remuneração alta (8000) \\
\hline $\mathbf{2}$ & 5 & OSFL DIVULGADORA_1 & com remuneração baixa (2000) \\
\hline $\mathbf{3}$ & 6 & OSFL DIVULGADORA_2 & com remuneração moderada (5000) \\
\hline $\mathbf{4}$ & 7 & OSFL DIVULGADORA_3 & com remuneração alta (8000) \\
\hline
\end{tabular}

Cada "grupo de divulgação" passa a ter novos códigos, resultando nos seguintes grupos: 1 - "OSFL sem informação de remuneração do dirigente", 2 - "OSFL com divulgação de remuneração do dirigente baixa", 3 - "OSFL com divulgação de remuneração do dirigente moderada" e 4 - "OSFL com divulgação de remuneração do dirigente alta".

Para analisar o efeito principal da remuneração sobre a variável dependente "valor doado", correspondente à hipótese de pesquisa H1a, utilizou-se a análise Kruskal Wallis. Primeiramente, a mesma foi feita incluindo todos os respondentes. Os resultados desta análise são apresentados no Quadro 19.

Quadro 18-Médias por grupo de remuneração do dirigente - KW

\begin{tabular}{|l|c|c|c|c|}
\hline \multirow{2}{*}{ Identificação da remuneração } & \multicolumn{2}{|c|}{ Valor doado } & \multicolumn{2}{c|}{ Valor doado* } \\
\cline { 2 - 5 } & Qtd & Média & Qtd & Média \\
\hline Sem informação de remuneração & 20 & 73,20 & 10 & 68,75 \\
\hline Remuneração baixa & 40 & 68,90 & 40 & 64,15 \\
\hline Remuneração moderada & 40 & 73,35 & 40 & 68,31 \\
\hline Remuneração alta & 40 & 67,90 & 40 & 63,23 \\
\hline Total & $\mathbf{1 4 0}$ & & $\mathbf{1 4 0}$ & $\mathbf{0 , 7 1 2}$ \\
\hline p-value KW & \multicolumn{2}{|c|}{$\mathbf{0 , 6 9 4}$} & \\
\hline
\end{tabular}

*Excluindo respondentes que não indicaram corretamente a remuneração do dirigente 
Os resultados do teste de Kruskal Wallis indicam que não houve diferença significante entre as médias do "valor doado" entre os grupos de "identificação da remuneração".2

Como não foi observado resultado significativo pelo teste de Kruskal Wallis, realizouse o teste U de Mann Whitney para analisar pares de grupos de variáveis. Mesmo verificadas qualitativamente médias de doação superiores para os grupos 1(sem informação da remuneração) e 3(remuneração moderada) em relação aos grupos 2 (remuneração baixa) e 4 (remuneração alta), com indícios que corroboram com os achados de Balsam e Harris (2014) e de Galle e Walker (2013), os quais identificaram que os doadores reduzem as contribuições subsequentemente ao disclosure de remunerações de dirigentes altas, assim como há indicativos de que, como tratado por Grasse et al. (2014), quando o dirigente recebe remuneração abaixo da média de mercado, este pode não se dedicar integralmente à OSFL para poder complementar seu sustento com outras atividades, os doadores também respondem a esta situação, para todas as comparações os resultados não foram significativos.

De forma geral, analisando os resultados encontrados, há um indicativo de que o valor divulgado da remuneração do dirigente pela OSFL não influencia significativamente no volume de recursos doados.

H1b: Quanto maior o valor divulgado de remuneração do dirigente da OSFL, menor a propensão de doação futura por parte do doador individual.

Inicialmente se realizou o teste Qui-quadrado comparativo entre o grupo de controle e os demais grupos para verificar se a divulgação da remuneração do dirigente, independentemente do valor, tem algum efeito na probabilidade de doar futuramente pelo doador individual. Não se encontrou significância na análise que indicasse associação entre a probabilidade de doar futuramente e a divulgação da remuneração do dirigente (nível de significância de 0,433).

Para analisar o efeito principal do montante da remuneração divulgada sobre a variável dependente "probabilidade de doar futuramente", correspondente à hipótese de pesquisa H1b, utilizou-se a análise Qui-quadrado, conforme resultados a seguir, considerando todos os respondentes.

\footnotetext{
${ }^{2}$ Os resultados são semelhantes (qui-quadrado 1,374 e nível de significância 0,712 ) com a exclusão dos respondentes que não indicaram corretamente a remuneração do dirigente ([a]quando o caso não possuía remuneração e a resposta para a percepção da doação foi diferente de "não lembro/não vi"; [b]quando o caso possuía remuneração e o respondente indicou como percepção "não lembro/não vi”). Optou-se por apresentar os resultados sem a exclusão.
} 
Quadro 19 - Efeito da remuneração - Qui-quadrado - frequências - Probabilidade de doar futuramente

\begin{tabular}{|l|c|c|c|c|c|}
\hline \multirow{2}{*}{$\begin{array}{c}\text { Probabilidade de doar } \\
\text { futuramente }\end{array}$} & $\begin{array}{c}\text { Identificação da remuneração } \\
\text { de remuneração }\end{array}$ & $\begin{array}{c}\text { Remuneração } \\
\text { baixa }\end{array}$ & $\begin{array}{c}\text { Remuneração } \\
\text { moderada }\end{array}$ & $\begin{array}{c}\text { Remuneração } \\
\text { alta }\end{array}$ & Total \\
\hline Nenhuma probabilidade & 3 & 5 & 6 & 9 & 23 \\
\hline Baixíssima probabilidade & 3 & 2 & 5 & 4 & 14 \\
\hline Baixa probabilidade & 4 & 7 & 6 & 7 & 24 \\
\hline Moderada probabilidade & 8 & 11 & 11 & 7 & 37 \\
\hline Alta probabilidade & 1 & 8 & 6 & 2 & 25 \\
\hline Altíssima probabilidade & 1 & 3 & 3 & 1 & 9 \\
\hline Doação certa & 0 & 4 & $\mathbf{4 0}$ & $\mathbf{4 0}$ & $\mathbf{1 4 0}$ \\
\hline TOTAL & $\mathbf{2 0}$ & $\mathbf{4 0}$ & & &
\end{tabular}

Ao analisar o teste Qui-quadrado, não se verifica resultado significante na associação entre "probabilidade de doar futuramente" e "identificação da remuneração".3

4.5.1.1 Análise de relações das variáveis de controle (covariáveis) considerando o efeito da divulgação da remuneração

Com o objetivo de verificar se alguma variável de controle interferiu no "valor doado" sob a perspectiva do efeito da divulgação da remuneração do dirigente pela OSFL, realizou-se a análise por meio do Coeficiente de Spearman (variáveis escalares, ordinais e nominais dicotômicas) e teste Qui-quadrado (variáveis nominais não dicotômicas) para cada grupo de remuneração divulgada: 1-“OSFL sem informação da remuneração" e 2-“OSFL com informação da remuneração baixa"; 3-“OSFL com informação da remuneração moderada”; 4"OSFL com informação da remuneração alta".

Verificou-se significância nos resultados para as variáveis "confiança na causa", "confiança total” (confiança ética; confiança não tira vantagem) para o Grupo 2 e Grupo 4, conforme Quadro 21 e, para a variável “escolaridade” para o Grupo 2 (Quadro 22) e a variável e "doação para asilo" para o Grupo 4 (Quadro 21). Para todas as demais variáveis e grupos não houve resultado significativo.

\footnotetext{
${ }^{3}$ Os resultados são semelhantes (nível de significância 0,948) com a exclusão dos respondentes que não indicaram corretamente a remuneração do dirigente ([a]quando o caso não possuía remuneração e a resposta para a percepção da doação foi diferente de "não lembro/não vi"; [b]quando o caso possuía remuneração e o respondente indicou como percepção "não lembro/não vi”). Optou-se por apresentar os resultados sem a exclusão.
} 
Quadro 20 - Análises adicionais - Efeito da remuneração x Variáveis Controle x Valor doado

\begin{tabular}{|l|l|c|c|}
\hline \multicolumn{2}{|c|}{ Variável de controle } & $\begin{array}{c}\text { Coeficiente de correlação - } \\
\text { valor doado }\end{array}$ & $p$-value \\
\hline \multirow{4}{*}{ Grupo 2 } & Confiança causa & $0,434 * *$ & 0,005 \\
\cline { 2 - 4 } & Confiança ética & $0,380 * *$ & 0,016 \\
\cline { 2 - 4 } & Confiança não tira vantagem & $0,318 * *$ & 0,046 \\
\hline \multirow{5}{*}{ Grupo 4 } & Confiança causa & $0,432 * *$ & 0,005 \\
\cline { 2 - 4 } & Confiança ética & $0,548 * *$ & 0,000 \\
\cline { 2 - 4 } & Confiança não tira vantagem & $0,520 * *$ & 0,001 \\
\cline { 2 - 4 } & Doação asilo & $-0,490^{* *}$ & 0,010 \\
\hline
\end{tabular}

Quadro 21 - Análises adicionais - Efeito da Remuneração x Variável "escolaridade" x Valor doado

\begin{tabular}{|c|c|c|c|c|}
\hline Grupo 2 & \multicolumn{3}{|c|}{ Escolaridade } & \multirow{2}{*}{ Total } \\
\hline Valor doado & Graduação & Especialização & Mestrado & \\
\hline 0 & 4 & 1 & 1 & 6 \\
\hline 10 & 32 & 2 & 0 & 34 \\
\hline Total & $\mathbf{3 6}$ & $\mathbf{3}$ & $\mathbf{1}$ & $\mathbf{4 0}$ \\
\hline p-value & $\mathbf{0 , 0 3 2}$ & \multicolumn{3}{|c}{} \\
\cline { 1 - 4 } & &
\end{tabular}

Na sequência, para analisar se alguma variável de controle interferiu na "probabilidade de doar futuramente" sob a perspectiva do efeito da divulgação da remuneração do dirigente pela OSFL, realizou-se a análise por meio do teste Qui-quadrado. Os resultados foram significantes para a variável "renda familiar" para o Grupo 3, conforme Quadro 23. Para todas as demais variáveis e grupos não houve significância. ${ }^{4}$

Quadro 22 - Análises adicionais - Efeito da Remuneração x Renda Familiar x Probabilidade de doar futuramente

\begin{tabular}{|c|c|c|c|c|c|c|}
\hline \multirow[b]{2}{*}{ Probabilidade } & \multicolumn{5}{|c|}{ Renda familiar } & \multirow[b]{2}{*}{ Total } \\
\hline & ATÉ 2 SM & $\begin{array}{c}+2 \text { SM } \\
\text { ATÉ } 4 \text { SM }\end{array}$ & $\begin{array}{c}+4 \text { SM ATÉ } \\
10 \mathrm{SM}\end{array}$ & $\begin{array}{c}+10 \mathrm{SM} \\
\text { ATÉ } 20 \mathrm{SM}\end{array}$ & $+20 \mathrm{SM}$ & \\
\hline Nenhuma probabilidade & 0 & 1 & 4 & 1 & 0 & 6 \\
\hline Baixíssima probabilidade & 0 & 2 & 2 & 1 & 0 & 5 \\
\hline Baixa probabilidade & 2 & 0 & 2 & 2 & 0 & 6 \\
\hline Moderada Probabilidade & 1 & 1 & 0 & 9 & 0 & 11 \\
\hline Alta probabilidade & 0 & 2 & 4 & 0 & 0 & 6 \\
\hline Altíssima probabilidade & 0 & 0 & 2 & 0 & 1 & 3 \\
\hline Doação certa & 1 & 1 & 0 & 0 & 1 & 3 \\
\hline Total & 4 & 7 & 14 & 13 & 2 & 40 \\
\hline p-value & 0,006 & & & & & \\
\hline
\end{tabular}

\footnotetext{
${ }^{4}$ Os resultados são semelhantes com a exclusão dos respondentes que não indicaram corretamente a remuneração do dirigente ([a]quando o caso não possuía remuneração e a resposta para a percepção da doação foi diferente de "não lembro/não vi"; [b]quando o caso possuía remuneração e o respondente indicou como percepção "não lembro/não vi”). Optou-se por apresentar os resultados sem a exclusão.
} 
4.5.2 Análise do efeito principal da empresa solidária apoiadora

As hipóteses de pesquisa que buscam identificar o efeito principal da divulgação da empresa solidária apoiadora da OSFL sobre a decisão do doador individual são descritas a seguir, com as devidas análises.

\section{H2a: OSFL que divulgam a informação sobre a empresa solidária apoiadora} recebem maior volume de doação pelo doador individual do que OSFL que não divulgam.

Para verificar o efeito principal da divulgação, cada "grupo de divulgação" foi reclassificado conforme segue:

Quadro 23 - Reclassificação de "grupo de divulgação" - efeito da divulgação da empresa solidária apoiadora

\begin{tabular}{|c|c|c|l|}
\hline \multicolumn{3}{|c|}{ EFEITO INTERATIVO ENTRE REMUNERAÇÃO E DIVULGAÇÃO } \\
\hline Novo código do grupo & Grupos & Grupo de "divulgação" & Definição da remuneração \\
\hline \multirow{3}{*}{1} & 1 & OSFL NÃO DIVULGADORA_1 & sem informação de remuneração \\
\cline { 2 - 4 } & 2 & OSFL NÃO DIVULGADORA_2 & com remuneração baixa (2000) \\
\cline { 2 - 4 } & 3 & OSFL NÃO DIVULGADORA_3 & com remuneração moderada (5000) \\
\cline { 2 - 4 } & 4 & OSFL NÃO DIVULGADORA_4 & com remuneração alta (8000) \\
\hline \multirow{3}{*}{2} & 5 & OSFL DIVULGADORA_1 & com remuneração baixa (2000) \\
\cline { 2 - 4 } & 6 & OSFL DIVULGADORA_2 & com remuneração moderada (5000) \\
\cline { 2 - 4 } & 7 & OSFL DIVULGADORA_3 & com remuneração alta (8000) \\
\hline
\end{tabular}

Com a nova reclassificação, a identificação por "grupo de divulgação" resultou em dois novos grupos: 1 - "OSFL não divulgadoras de empresa solidária apoiadora" e 2 - "OSFL divulgadoras de empresa solidária apoiadora".

Para analisar o efeito principal da divulgação sobre a variável dependente "valor doado", correspondente à hipótese de pesquisa H2a, utilizou-se a análise Kruskal Wallis, conforme resultados a seguir. ${ }^{5}$

\begin{tabular}{|c|c|c|}
\hline $\begin{array}{c}\text { Identificação - Divulgação da empresa } \\
\text { solidária apoiadora }\end{array}$ & Qtd & Média \\
\hline OSFL NÃO DIVULGADORA & 80 & 71,28 \\
\hline OSFL DIVULGADORA & 60 & 69,47 \\
\hline Total & 140 & \\
\hline p-value & 0,661 & \\
\hline
\end{tabular}

\footnotetext{
5 Os resultados são semelhantes (qui-quadrado 0,145 e nível de significância 0,703 ) com a exclusão dos respondentes que não indicaram corretamente a remuneração do dirigente ([a]quando o caso não possuía remuneração e a resposta para a percepção da doação foi diferente de "não lembro/não vi"; [b]quando o caso possuía remuneração e o respondente indicou como percepção "não lembro/não vi”). Optou-se por apresentar os resultados sem a exclusão.
} 
Comparando-se a média do valor doado entre o grupo de OSFL que divulga a empresa solidária apoiadora e o grupo que não divulga, os resultados indicam um qui-quadrado igual a 0,193 e nível de significância 0,661 , não havendo diferença significativa. ${ }^{6}$

H2b: OSFL que divulgam a informação sobre a empresa solidária apoiadora obtém maior propensão de doação futura pelo doador individual do que OSFL que não divulgam.

Para analisar o efeito principal da divulgação sobre a variável dependente "probabilidade de doar futuramente", correspondente à hipótese de pesquisa H2b, utilizou-se a análise Qui-quadrado, conforme resultados a seguir. ${ }^{7}$

Quadro 25 - Efeito da divulgação - Qui-quadrado frequências - Probabilidade de doar futuramente

\begin{tabular}{|l|c|c|c|}
\hline \multirow{2}{*}{\begin{tabular}{c}
\multirow{2}{*}{$\begin{array}{c}\text { Probabilidade de doar } \\
\text { futuramente }\end{array}$} \\
\cline { 2 - 4 }
\end{tabular}} & \multicolumn{2}{|c|}{$\begin{array}{c}\text { Grupo de “divulgação" } \\
\text { OSFL NÃO DIVULGADORA }\end{array}$} & \multirow{2}{*}{ TIVULGADORA } \\
\hline Nenhuma probabilidade & 13 & 10 & 23 \\
\hline Baixíssima probabilidade & 8 & 6 & 14 \\
\hline Baixa probabilidade & 15 & 9 & 24 \\
\hline Moderada Probabilidade & 25 & 12 & 37 \\
\hline Alta probabilidade & 10 & 15 & 25 \\
\hline Altíssima probabilidade & 8 & 1 & 9 \\
\hline Doação certa & 1 & 7 & 8 \\
\hline Total & $\mathbf{8 0}$ & $\mathbf{6 0}$ & $\mathbf{1 4 0}$ \\
\hline p-value & $\mathbf{0 , 0 1 9}$ & & \\
\hline
\end{tabular}

O resultado da análise da associação entre o efeito principal da divulgação da empresa solidária apoiadora pela OSFL foi significativo. Em análise qualitativa se observa maior frequência no total das respostas "probabilidade alta", "probabilidade altíssima" e "doação certa" (28\% a mais) quando a OSFL divulga a empresa solidária apoiadora do que quando não divulga. Além disso, considerando as respostas "nenhuma probabilidade", "baixíssima probabilidade" e "baixa probabilidade" em conjunto, observa-se uma frequência 44\% maior para OSFL que não divulgam a empresa solidária apoiadora do que as OSFL divulgadoras.

\footnotetext{
${ }^{6}$ Os resultados são semelhantes (qui-quadrado 0,065 e nível de significância 0,798 ) excluindo-se o grupo de controle (OSFL não divulgadora e sem informação da remuneração do dirigente - Quadro 21)

${ }^{7}$ Os resultados são semelhantes com a exclusão dos respondentes que não indicaram corretamente a remuneração do dirigente ([a]quando o caso não possuía remuneração e a resposta para a percepção da doação foi diferente de "não lembro/não vi"; [b]quando o caso possuía remuneração e o respondente indicou como percepção "não lembro/não vi”). Optou-se por apresentar os resultados sem a exclusão.
} 
Em relação à teoria, os achados demonstram que há indícios que divulgar a empresa solidária apoiadora por parte da OSFL gera o compliance sobre o doador, conforme afirmam Cialdini e Trost (1998) que relatam a resposta em consentimento com a OSFL devido a uma fonte de autoridade legítima, fazendo com que a propensão para doar no futuro novamente para a OSFL seja maior. Desta forma, rejeita-se a hipótese nula e se admite a hipótese alternativa do teste estatístico, aceitando-se, em consequência, a hipótese $\mathrm{H} 2 \mathrm{~b}$ do estudo, que estabelece que uma maior propensão de doação futura ocorre quando a OSFL divulga informação sobre a empresa solidária apoiadora do que quando ela não divulga.

Os resultados demonstram, portanto, que há indícios de que, possivelmente a empresa solidária apoiadora tenha gerado confiança no doador de que a OSFL cumpre com sua missão social, ao mostrar boa reputação organizacional e fazendo com que o papel de monitoradora da empresa fosse percebido, conforme afirmam Yetman e Yetman (2013), Petrovits, Shakespeare e Shih (2011), Okten e Weisbrod (2000), causando um efeito atrativo sobre a probabilidade da contribuição futura por parte do doador individual.

4.5.2.1 Análise de relações das variáveis de controle (covariáveis) considerando o efeito da divulgação da empresa solidária apoiadora

Com o objetivo de verificar se alguma variável de controle interferiu no "valor doado" sob a perspectiva do efeito da divulgação da remuneração do dirigente pela OSFL, realizou-se a análise por meio do Coeficiente de Spearman (variáveis escalares, ordinais e nominais dicotômicas) e teste Qui-quadrado (variáveis nominais não dicotômicas) para cada grupo: 1 “OSFL divulgadora de empresa solidária apoiadora" e 2 - "OSFL não divulgadora de empresa solidária apoiadora".

Observou-se significância nos resultados para as variáveis "confiança na causa", "confiança total" (confiança ética; confiança não tira vantagem) para o ambos os grupos e das variáveis “doação para asilo" e "escolaridade” para o Grupo 2, conforme Quadros 27 e 28. Para todas as demais variáveis e grupos não houve resultado significativo. 
Quadro 26 - Análises adicionais - Efeito da divulgação x Variáveis Controle x Valor doado

\begin{tabular}{|c|l|c|c|}
\hline \multicolumn{2}{|c|}{ Variável de controle } & $\begin{array}{c}\text { Coeficiente de correlação - } \\
\text { valor doado }\end{array}$ & p-value \\
\hline \multirow{4}{*}{ Grupo 1 } & Confiança causa & $0,321^{* *}$ & 0,004 \\
\cline { 2 - 4 } & Confiança ética & $0,339 * *$ & 0,002 \\
\cline { 2 - 4 } & Confiança não tira vantagem & $0,302 * *$ & 0,006 \\
\hline \multirow{4}{*}{ Grupo 2 } & Confiança causa & $0,329 * *$ & 0,010 \\
\cline { 2 - 4 } & Confiança ética & $0,466^{* *}$ & 0,000 \\
\cline { 2 - 4 } & Confiança não tira vantagem & $0,366^{* *}$ & 0,004 \\
\cline { 2 - 4 } & Doação asilo & $-0,434 * *$ & 0,006 \\
\hline
\end{tabular}

Quadro 27 - Análises adicionais - Efeito da Divulgação x Variável "escolaridade" x Valor doado

\begin{tabular}{|c|c|c|c|c|}
\hline Grupo 2 & \multicolumn{3}{|c|}{ Escolaridade } & \multirow{2}{*}{ Total } \\
\cline { 1 - 4 } Valor doado & Graduação & Especialização & Mestrado & \\
\hline 0 & 3 & 1 & 1 & 5 \\
\hline 5 & 4 & 0 & 0 & 4 \\
\hline 10 & 42 & 9 & 0 & 51 \\
\hline Total & $\mathbf{4 9}$ & $\mathbf{1 0}$ & $\mathbf{1}$ & $\mathbf{6 0}$ \\
\hline p-value & $\mathbf{0 , 0 1 6}$ & \multicolumn{3}{c}{} \\
\cline { 1 - 3 } & & &
\end{tabular}

Na sequência, para analisar se alguma variável de controle interferiu na "probabilidade de doar futuramente" sob a perspectiva do efeito da divulgação da remuneração do dirigente pela OSFL, realizou-se a análise por meio do teste Qui-quadrado. Para todas as variáveis e grupos não houve significância.

4.5.3 Análise do efeito interativo entre divulgação de remuneração e empresa solidária apoiadora

Para verificar o efeito interativo entre divulgação da remuneração e divulgação de empresa solidária apoiadora da OSFL, cada "grupo de divulgação" foi reclassificado conforme segue:

Quadro 28 - Reclassificação de "grupo de divulgação" - efeito interativo da divulgação empresa solidária apoiadora e da remuneração do dirigente

\begin{tabular}{|c|c|c|l|}
\hline \multicolumn{5}{|c|}{ EFEITO INTERATIVO ENTRE REMUNERAÇÃO E DIVULGAÇÃO } \\
\hline Novo código do grupo & Grupos & Grupo de "divulgação" & Definição da remuneração \\
\hline $\mathbf{1}$ & 1 & OSFL NÃO DIVULGADORA_1 & sem informação de remuneração \\
\hline \multirow{2}{*}{2} & 2 & OSFL NÃO DIVULGADORA_2 & com remuneração baixa (2000) \\
\cline { 2 - 5 } & 3 & OSFL NÃO DIVULGADORA_3 & com remuneração moderada (5000) \\
\cline { 2 - 4 } & 4 & OSFL NÃO DIVULGADORA_4 & com remuneração alta (8000) \\
\hline \multirow{3}{*}{3} & 5 & OSFL DIVULGADORA_1 & com remuneração baixa (2000) \\
\cline { 2 - 4 } & 6 & OSFL DIVULGADORA_2 & com remuneração moderada (5000) \\
\cline { 2 - 4 } & 7 & OSFL DIVULGADORA_3 & com remuneração alta (8000) \\
\hline
\end{tabular}


Para analisar o efeito interativo entre a divulgação e a remuneração sobre a variável dependente "valor doado", a pesquisa apresentou as seguintes hipóteses:

H3a: OSFL que divulgam a empresa solidária apoiadora e a remuneração do dirigente recebem um maior volume de doações por parte do doador individual do que OSFL que não divulgam.

A hipótese de pesquisa $\mathrm{H} 3 \mathrm{a}$ foi analisada por meio do teste de Kruskal Wallis, conforme resultados a seguir. ${ }^{8}$

Quadro 29 - Médias por grupo - interação - divulgadora de empresa solidária apoiadora e de remuneração do dirigente- KW

\begin{tabular}{|l|c|c|}
\hline \multirow{2}{*}{ Grupo de “divulgação" } & \multicolumn{2}{c|}{ Valor doado } \\
\cline { 2 - 3 } & Qtd & Média \\
\hline GRUPO DE CONTROLE & 20 & 73,20 \\
\hline OSFL NÃO DIVULGADORA & 60 & 70,63 \\
\hline OSFL DIVULGADORA & 60 & 69,47 \\
\hline Total & $\mathbf{1 4 0}$ & \\
\hline \multicolumn{2}{|r}{ p-value } & $\mathbf{0 , 8 3 4}$ \\
\cline { 2 - 2 }
\end{tabular}

Comparando-se a média do valor doado entre o grupo de OSFL que divulga a empresa solidária apoiadora e o grupo que não divulga, não houve diferença significativa (nível de significância 0,834 e qui-quadrado 0,362 ).

Para analisar o efeito interativo entre a divulgação e a remuneração sobre a variável dependente "probabilidade de doar futuramente", a pesquisa enunciou a hipótese de pesquisa $\mathrm{H} 3 \mathrm{~b}$.

H3b: OSFL que divulgam a empresa solidária apoiadora e a remuneração do dirigente obtém maior propensão de doações futuras por parte do doador individual do que OSFL que não divulgam.

Para análise da hipótese H3b, utilizou-se a análise Qui-quadrado, conforme resultado a seguir, excluindo os respondentes que não indicaram corretamente a remuneração do dirigente ([a]quando o caso não possuía remuneração e a resposta para a percepção da doação foi diferente de "não lembro/não vi"; [b]quando o caso possuía remuneração e o respondente

\footnotetext{
${ }^{8}$ Os resultados são semelhantes (nível de significância 0,863 e qui-quadrado 0,294) com a exclusão dos respondentes que não indicaram corretamente a remuneração do dirigente ([a]quando o caso não possuía remuneração e a resposta para a percepção da doação foi diferente de "não lembro/não vi"; [b]quando o caso possuía remuneração e o respondente indicou como percepção "não lembro/não vi") e com a exclusão do grupo de controle (nível de significância 0,798 e qui-quadrado 0,065). Optou-se por apresentar os resultados sem a exclusão.
} 
indicou como percepção "não lembro/não vi"). ${ }^{9} \mathrm{O}$ resultado da análise da associação entre o efeito principal da divulgação da empresa solidária apoiadora pela OSFL e a probabilidade de doar futuramente não foi significativa (nível de significância 0,276), conforme Quadro 31.

Quadro 30 - Efeito interativo da divulgação de empresa solidária apoiadora e de remuneração do dirigente - Quiquadrado frequências - Probabilidade de doar futuramente

\begin{tabular}{|c|c|c|c|c|}
\hline \multirow[b]{2}{*}{ Probabilidade } & \multicolumn{3}{|c|}{ Grupo de “divulgação" } & \multirow[b]{2}{*}{ Total } \\
\hline & $\begin{array}{l}\text { Grupo de } \\
\text { controle }\end{array}$ & $\begin{array}{c}\text { OSFL não } \\
\text { divulgadora }\end{array}$ & $\begin{array}{c}\text { OSFL } \\
\text { divulgadora }\end{array}$ & \\
\hline Nenhuma probabilidade & 1 & 10 & 10 & 21 \\
\hline Baixíssima probabilidade & 1 & 5 & 6 & 12 \\
\hline Baixa probabilidade & 2 & 11 & 9 & 22 \\
\hline Moderada Probabilidade & 4 & 17 & 12 & 33 \\
\hline Alta probabilidade & 1 & 9 & 15 & 25 \\
\hline Altíssima probabilidade & 1 & 7 & 1 & 9 \\
\hline Doação certa & 0 & 1 & 7 & 8 \\
\hline Total & 10 & 60 & 60 & 130 \\
\hline p-value & 0,276 & & & \\
\hline
\end{tabular}

4.5.3.1 Análise de relações das variáveis de controle (covariáveis) considerando o efeito interativo entre a divulgação da remuneração e da empresa solidária apoiadora

Com o objetivo de verificar se alguma variável de controle interferiu no "valor doado" sob a perspectiva do efeito da divulgação da remuneração do dirigente pela OSFL, realizou-se a análise por meio do Coeficiente de Spearman (variáveis escalares, ordinais e nominais dicotômicas) e teste Qui-quadrado (variáveis nominais não dicotômicas) para cada grupo: 1 "Grupo de controle (sem informação de empresa solidária apoiadora e sem informação de remuneração)"; 2 - "OSFL não divulgadora de empresa solidária apoiadora e com informação de remuneração"; 3 - "OSFL divulgadora de empresa solidária apoiadora e com informação de remuneração".

Evidenciou-se significância nos resultados para as variáveis "confiança na causa", "confiança total" (confiança ética; confiança não tira vantagem) para o Grupo 2 e Grupo 3 e das variáveis "doação para asilo" e "escolaridade" para o Grupo 3, conforme Quadros 32 e 28. Para todas as demais variáveis e grupos não houve resultado significativo.

\footnotetext{
${ }^{9}$ Realizou-se também a análise com todos os respondentes. Os resultados são significativos ao nível de confiança de $90 \%$ e valor crítico de 0,1 (nível de significância 0,099).
} 
Quadro 31 - Análises adicionais - Efeito da interação x Variáveis Controle x Valor doado

\begin{tabular}{|c|l|c|c|}
\hline \multicolumn{2}{|c|}{ Variável de controle } & $\begin{array}{c}\text { Coeficiente de correlação - } \\
\text { valor doado }\end{array}$ & p-value \\
\hline \multirow{3}{*}{$\begin{array}{c}\text { Grupo } \\
\mathbf{2}\end{array}$} & Confiança causa & $0,286^{* *}$ & 0,027 \\
\cline { 2 - 4 } & Confiança ética & $0,316^{* *}$ & 0,014 \\
\cline { 2 - 4 } & Confiança não tira vantagem & $0,256^{* *}$ & 0,048 \\
\hline \multirow{3}{*}{ Grupo } & Confiança causa & $0,329^{* *}$ & 0,01 \\
\cline { 2 - 4 } $\mathbf{4}$ & Confiança ética & $0,466^{* *}$ & 0 \\
\cline { 2 - 4 } & Confiança não tira vantagem & $0,366^{* *}$ & 0,004 \\
\cline { 2 - 4 } & Doação asilo & $-0,434^{* *}$ & 0,006 \\
\hline
\end{tabular}

Na sequência, para analisar se alguma variável de controle interferiu na "probabilidade de doar futuramente" sob a perspectiva do efeito da divulgação da remuneração do dirigente pela OSFL, realizou-se a análise por meio do teste Qui-quadrado. Verificou-se significância para a variável "doação para OSFL Laica"10 para o Grupo 2, conforme Quadro 33. Para todas as demais variáveis e grupos não houve significância.

Quadro 32 - Análises adicionais - Efeito da Interação x Doação Laica x Probabilidade de doar futuramente

\begin{tabular}{|l|c|c|c|}
\hline Grupo 2 & \multicolumn{2}{|c|}{ LAICA } & \multirow{2}{*}{ Total } \\
\hline Probabilidade & NÃO & SIM & 7 \\
\hline Nenhuma probabilidade & 3 & 4 & 7 \\
\hline Baixíssima probabilidade & 3 & 0 & 3 \\
\hline Baixa probabilidade & 5 & 2 & 7 \\
\hline Moderada Probabilidade & 7 & 9 & 16 \\
\hline Alta probabilidade & 3 & 4 & 7 \\
\hline Altíssima probabilidade & 0 & 5 & 5 \\
\hline Doação certa & 1 & 0 & 1 \\
\hline Total & $\mathbf{2 2}$ & $\mathbf{2 4}$ & $\mathbf{4 6}$ \\
\cline { 1 - 2 } & $\mathbf{0 , 0 9 6}$ & &
\end{tabular}

De forma geral, os resultados, separados por remuneração ou por divulgação de empresa solidária apoiadora ou pela interação das duas variáveis, confirmam os achados de Pereira (2006) que afirma que, após verificarem a causa, os doadores precisam sentir confiança na OSFL para concretizarem a doação e, da mesma forma, Cruz (2010) assinala que doadores preferem contribuir para OSFL que sejam dignas de credibilidade e confiança.

\subsection{Análises adicionais - Comparação entre condições experimentais}

Como análise adicional à pesquisa, buscou-se verificar se existe diferença no montante de contribuição do doador individual e na propensão de doar futuramente quando a OSFL não divulga a empresa solidária apoiadora, comparando-se todos os níveis de disclosure de

\footnotetext{
${ }^{10}$ Os resultados são significativos ao nível de confiança de $90 \%$ e valor crítico 0,1 .
} 
remuneração do dirigente: "sem informação", "remuneração baixa", "remuneração moderada" e "remuneração alta".

Para analisar o montante de contribuição, inicialmente se realizou a separação dos grupos. Para a identificação "grupo de divulgação" havia sete grupos. Por meio da função "select cases" do SPSS, selecionou-se apenas os grupos 1, 2, 3 e 4 (Quadro 8), que correspondem aos grupos de OSFL não divulgadoras de empresa solidária apoiadora (O Boticário).

Foi feita a análise Kruskal Wallis (KW) de cada "grupo de divulgação" e a variável "valor doado", encontrando o seguinte resultado:

Quadro 33 - Análise adicional - Remuneração do dirigente x Valor doado - KW (não divulgadora)

\begin{tabular}{|c|c|c|c|}
\hline \multirow{2}{*}{ Grupo } & \multirow{2}{*}{ Grupo de "divulgação" } & \multicolumn{2}{|c|}{ Valor doado } \\
\hline & & Qtd & Média \\
\hline 1 & Não divulgadora e sem informação de remuneração & 20 & 42,45 \\
\hline 2 & Não divulgadora e remuneração baixa & 20 & 38,35 \\
\hline 3 & Não divulgadora e remuneração moderada & 20 & 40,60 \\
\hline 4 & Não divulgadora e remuneração alta & 20 & 40,60 \\
\hline & Total & 80 & \\
\hline & p-value KW & 0,764 & \\
\hline
\end{tabular}

Como não houve diferença estatística significativa para o teste $\mathrm{KW}$, foi feito a análise U de Mann Whitney, buscando-se fazer a comparação de média da variável "valor doado" entre duplas de grupos de "grupo de divulgação", separadamente.

Importante ressaltar que, na verificação de significância do teste U de Mann Whitney, é preciso evitar o Erro Tipo 1, que é inflacionar a taxa de erro por realizar várias comparações. Assim, para não ultrapassar o valor de 0,05, aplicou-se a correção de Bonferroni, a qual na sua forma mais simples significa que, ao invés de utilizar um valor crítico de 0,05 para cada teste, deve-se utilizar o valor 0,05 , dividido pelo número de testes que se irá realizar. É importante cuidar com a quantidade de testes a serem realizados, pois isso pode significar em um valor crítico muito pequeno. A seguir, apresenta-se a matriz para identificação da quantidade de comparações necessárias:

Quadro 34 - Matriz de comparações necessárias - Remuneração do dirigente x Valor doado - MW (não divulgadora)

\begin{tabular}{|l|l|l|l|l|}
\hline & Grupo 1 & Grupo 2 & Grupo 3 & Grupo 4 \\
\hline Grupo 1 & & & & \\
\hline Grupo 2 & $*$ & & & \\
\hline Grupo 3 & $*$ & $*$ & & \\
\hline Grupo 4 & & & \\
\hline
\end{tabular}


Conforme matriz de comparações necessárias, verifica-se a necessidade de 3 comparações de grupos. Como foi identificado na análise de KW que a média entre o Grupo 3 e Grupo 4 é igual, não há necessidade de fazer um teste de diferença de média entre eles e também, apenas comparar cada grupo com o grupo 3 já é suficiente. O valor crítico de $p$-value ficou em $1,66 \%(0,05 / 3)$. Para todas as comparações, não se verificou diferença estatística significativa.

A análise da probabilidade de doar futuramente, ainda com a base de dados selecionada para "grupo de divulgação", apenas com os grupos 1, 2, 3 e 4, que correspondem a grupos de OSFL não divulgadora de empresa solidária apoiadora (O Boticário), foi realizada pelo teste Qui-quadrado para independência, buscando-se verificar se os grupos de "grupo de divulgação" e a variável "probabilidade de doar futuramente" estão relacionadas. Para todas as comparações, os resultados não foram significativos.

Esta mesma análise se existe diferença no montante de contribuição e na probabilidade de doar futuramente pelo doador individual conforme o nível de remuneração do dirigente reportado pela OSFL também foi realizada para OSFL que divulgam a empresa solidária apoiadora.

Para análise do montante de contribuição, inicialmente se realizou a separação dos grupos. Para "grupo de divulgação" havia sete grupos. Por meio da função "select cases" do SPSS, selecionaram-se apenas os grupos 5, 6 e 7 (Quadro 8), que correspondem a grupos de OSFL divulgadora de empresa solidária apoiadora (O Boticário). Foi feita a análise Kruskal Wallis (KW) de cada "grupo de divulgação" e a variável "valor doado", não havendo significância nos resultados.

Como não houve diferença estatística significativa para o teste KW, foi feito a análise U de Mann Whitney, a fim de se fazer a comparação de média da variável "valor doado" entre duplas de grupos de "grupo de divulgação", separadamente.

Importante ressaltar que, também nesta etapa, buscou-se evitar o Erro Tipo 1, que é inflacionar a taxa de erro por realizar várias comparações. Assim, para não ultrapassar o valor de 0,05 , aplicou-se a correção de Bonferroni, que na sua forma mais simples significa que, ao invés de utilizar um valor crítico de 0,05 para cada teste, deve-se empregar o valor 0,05, dividido pelo número de testes que se irá realizar. É importante cuidar com a quantidade de testes a serem realizados, pois isso pode significar em um valor crítico muito pequeno. Abaixo a matriz para identificação da quantidade de comparações necessárias: 
Quadro 35 - Matriz de comparações necessárias - Empresa solidária apoiadora x Valor doado - MW

\begin{tabular}{|l|l|l|l|}
\hline & Grupo 5 & Grupo 6 & Grupo 7 \\
\hline Grupo 5 & & & \\
\hline Grupo 6 & $*$ & & \\
\hline Grupo 7 & $*$ & $*$ & \\
\hline
\end{tabular}

Conforme matriz de comparações necessárias, verifica-se a necessidade de 3 comparações de grupos. O valor crítico de p-value ficou em 1,66\% (0,05/3). Para a comparação entre os grupos " $5=$ OSFL divulgadora da empresa solidária apoiadora e com informação de remuneração do dirigente baixa (R\$2.000)" e " $6=$ OSFL divulgadora da empresa solidária apoiadora e com informação de remuneração do dirigente moderada (R \$5.000)", e "5= OSFL divulgadora da empresa solidária apoiadora e com informação de remuneração do dirigente baixa (R 2.000$)$ " e "7= OSFL divulgadora da empresa solidária apoiadora e com informação de remuneração do dirigente alta (R \$8.000)", não se registrou significância nos resultados.

Na sequência, apresenta-se a análise de comparação de média de "valor doado" entre “ $6=$ OSFL divulgadora da empresa solidária apoiadora e com informação de remuneração do dirigente moderada (R \$5.000)" e "7= OSFL divulgadora da empresa solidária apoiadora e com informação de remuneração do dirigente alta (R $\$ 8.000)$ ”.

Quadro 36 - Análise adicional - médias MW - Remuneração do dirigente x Valor doado - G6 e G7 (divulgadora)

\begin{tabular}{|c|lr|c|c|}
\hline \multirow{2}{*}{ Grupo } & \multicolumn{2}{|c|}{ Grupo de “divulgação" } & \multicolumn{2}{c|}{ Valor doado } \\
\cline { 3 - 4 } & \multicolumn{1}{|c|}{ Qtd } & Média \\
\hline 6 & Divulgadora e remuneração moderada & 20 & 22,55 \\
\hline 7 & Divulgadora e remuneração alta & 20 & 18,45 \\
\hline \multicolumn{2}{r}{} & $\mathbf{4 0}$ & \\
\hline & p-value $\mathbf{K W}$ & $\mathbf{0 , 0 7 4}$ & \\
\end{tabular}

Quando a OSFL divulga empresa solidária apoiadora e divulga informação sobre remuneração do dirigente moderada $(\mathrm{R} \$ 5.000)$ em relação à OSFL divulgadora da empresa solidária apoiadora com informação de remuneração do dirigente alta (R \$8.000), a diferença é estatisticamente significante. Isso indica que ao analisar comparativamente OSFL divulgadoras da empresa solidária apoiadora, valores maiores de remuneração "expulsam doações" em relação à valores moderados de remuneração do dirigente divulgados. Há indícios de que remunerações de dirigentes moderadas sejam melhor percebidas pelos doadores em relação à altas remunerações, visto a redução na média de contribuições para 
OSFL subsequente ao disclosure de alta compensação do executivo (Balsam \& Harris, 2014; Galle \& Walker, 2013).

Com o objetivo de testar se existe diferença na média do valor doado em relação ao valor divulgado da remuneração do dirigente considerando a divulgação ou não da empresa solidária apoiadora, realizou-se o teste U de Mann Whitney para os seguintes pares de grupos de "grupo de divulgação":

(1) Diferença de média de valor doado entre Grupo 2 (OSFL não divulgadora da empresa solidária apoiadora com divulgação de valor da remuneração do dirigente baixa - R\$2.000) e Grupo 5 (OSFL divulgadora da empresa solidária apoiadora com divulgação de valor da remuneração do dirigente baixa - R \$2.000)

(2) Diferença de média de valor doado entre Grupo 3 (OSFL não divulgadora da empresa solidária apoiadora com divulgação de valor da remuneração do dirigente baixa - R\$5.000) e Grupo 6 (OSFL divulgadora da empresa solidária apoiadora com divulgação de valor da remuneração do dirigente baixa - R \$5.000).

(3) Diferença de média de valor doado entre Grupo 4 (OSFL não divulgadora da empresa solidária apoiadora com divulgação de valor da remuneração do dirigente baixa - R\$8.000) e Grupo 7 (OSFL divulgadora da empresa solidária apoiadora com divulgação de valor da remuneração do dirigente baixa - R \$8.000);

Diante das análises dos três pares de grupos de "grupo de divulgação", comparando-se OSFL divulgadora de empresa solidária apoiadora e OSFL não divulgadora de empresa solidária apoiadora, não houve diferença significativa.

Para a análise da probabilidade de doar futuramente, ainda com a base de dados selecionadas para "grupo de divulgação", apenas com os grupos 5, 6 e 7, que correspondem a grupos de OSFL divulgadora de empresa solidária apoiadora (O Boticário), realizou-se a análise Qui-quadrado para independência, buscando-se verificar se os grupos de "grupo de divulgação" e a variável "probabilidade de doar futuramente" estão relacionados. Observou-se que o teste qui-quadrado indica que não existe diferença significativa entre os grupos de "grupo de divulgação" para a probabilidade de doar futuramente quando a OSFL divulga a empresa solidária apoiadora. 


\subsection{Análises adicionais: análise das variáveis moderadoras}

As variáveis moderadoras são as seguintes:

a) Confiança Causa

b) Confiança Total ("confiança ética", "confiança uso recursos", "confiança não tira vantagem", "confiança técnicas respeitosas"), representado nos testes pelas variáveis "confiança ética" e "confiança não tira vantagem" que possuem maior percentual de explicação do fator.

c) AFECE é Confiável

A análise de moderação das variáveis relativas à confiança buscou verificar se o relacionamento entre as variáveis independentes (remuneração e empresa solidária apoiadora) e as variáveis dependentes (doação e doação futura) da pesquisa difere para grupos de maior confiança e grupos de menor confiança por meio do teste de Kruskal Wallis, U de Mann Whitney e Qui-quadrado. Os dados foram reclassificados, para cada variável moderadora (confiança causa; confiança total; e AFECE é confiável), em variáveis dicotômicas a partir da mediana: 1 - "maior confiança" e 0 - "menor confiança. Agrupou-se as variáveis independentes com as variáveis moderadoras, conforme Quadro 38 e 39.

Quadro 37 - Agrupamento das Variáveis Moderadoras e da Remuneração

\begin{tabular}{|c|l|l|}
\hline Grupo & Nível de confiança & Nível de remuneração \\
\hline $\mathbf{1}$ & Menor confiança & Remuneração baixa \\
\hline $\mathbf{2}$ & Menor confiança & Remuneração moderada \\
\hline $\mathbf{3}$ & Menor confiança & Remuneração alta \\
\hline $\mathbf{4}$ & Maior confiança & Remuneração baixa \\
\hline $\mathbf{5}$ & Maior confiança & Remuneração moderada \\
\hline $\mathbf{6}$ & Maior confiança & Remuneração alta \\
\hline
\end{tabular}

Quadro 38 - Agrupamento das Variáveis Moderadoras e da Divulgação da Empresa Solidária apoiadora

\begin{tabular}{|c|l|l|}
\hline Grupo & Nível de confiança & Empresa solidária apoiadora \\
\hline $\mathbf{1}$ & Menor confiança & Divulga \\
\hline $\mathbf{2}$ & Menor confiança & Não divulga \\
\hline $\mathbf{3}$ & Maior confiança & Divulga \\
\hline $\mathbf{4}$ & Maior confiança & Não divulga \\
\hline
\end{tabular}

Para a variável "confiança causa" a mediana é 4 (quatro). Optou-se por considerar para compor os grupos o seguinte critério: valores maiores que quatro para "maior confiança que a 
AFECE atua para o melhor interesse em prol da causa" e valores menores ou iguais a quatro para "menor confiança que a AFECE atua para o melhor interesse em prol da causa".

Para a variável "Confiança Total" (somatório das variáveis "confiança ética", “confiança uso recursos", “confiança não tira vantagem" e "confiança técnicas respeitosas”), a mediana é 14 (quatorze). Optou-se por considerar para compor os grupos o seguinte critério: valores maiores que quatorze para "maior confiança total" e valores menores ou iguais a quatorze para "menor confiança total".

Para a variável "AFECE é confiável”, a mediana é 3 (três). Optou-se por considerar para compor os grupos o seguinte critério: valores maiores que três para "maior confiança na AFECE" e valores menores ou iguais a três para "menor confiança na AFECE".

$\mathrm{O}$ teste de diferença de média para o efeito de todas as variáveis moderadoras foi significativo nas relações entre as variáveis independentes (remuneração do dirigente e empresa solidária apoiadora) e a variável dependente do valor doado.

O efeito da moderação das variáveis de confiança na relação entre remuneração e valor doado apresentou os seguintes resultados: variável "confiança causa" com qui-quadrado 12,576 e nível de significância 0,028; variável "confiança total” com qui-quadrado 21,886 e nível de significância 0,001 ; e a variável “AFECE é confiável” com qui-quadrado 14,406 e nível de significância 0,013, conforme Quadro 40.

Quadro 39 - Efeito da moderação das variáveis de confiança na relação entre Remuneração e Valor doado

\begin{tabular}{|c|c|c|c|c|c|c|c|}
\hline \multirow{3}{*}{ Grupo } & \multirow{3}{*}{ Relação } & \multicolumn{6}{|c|}{ Valor doado } \\
\hline & & \multicolumn{2}{|c|}{ Confiança causa } & \multicolumn{2}{|c|}{ Confiança total } & \multicolumn{2}{|c|}{ Confiança AFECE } \\
\hline & & Qtd & Média & Qtd & Média & Qtd & Média \\
\hline 1 & $\begin{array}{l}\text { Menor Confiança X } \\
\text { Remuneração Baixa } \\
\end{array}$ & 27 & 54,50 & 23 & 52,07 & 25 & 53,38 \\
\hline 2 & \begin{tabular}{|l|} 
Menor Confiança X \\
Remuneração Moderada \\
\end{tabular} & 30 & 62,73 & 22 & 65,64 & 21 & 62,88 \\
\hline 3 & \begin{tabular}{|l} 
Menor Confiança X \\
Remuneração Alta \\
\end{tabular} & 25 & 52,14 & 17 & 44,44 & 17 & 48,15 \\
\hline 4 & $\begin{array}{l}\text { Maior Confiança X } \\
\text { Remuneração Baixa }\end{array}$ & 13 & 68,50 & 17 & 68,50 & 15 & 68,50 \\
\hline 5 & \begin{tabular}{|l|} 
Maior Confiança X \\
Remuneração Moderada \\
\end{tabular} & 10 & 68,50 & 18 & 62,39 & 19 & 65,61 \\
\hline 6 & $\begin{array}{l}\text { Maior Confiança X } \\
\text { Remuneração Alta }\end{array}$ & 15 & 68,50 & 23 & 68,50 & 23 & 65,76 \\
\hline & Total & 120 & & 120 & & 120 & \\
\hline & p-value & \multicolumn{2}{|c|}{0,028} & \multicolumn{2}{|c|}{0,001} & \multicolumn{2}{|c|}{0,013} \\
\hline
\end{tabular}

Para a relação entre divulgar a remuneração do dirigente e valor doado, em que o resultado não foi significativo na análise da hipótese (H1a), a análise a partir da mediação 
indica que os participantes doam um volume maior de recursos quando confiam mais em comparação aos que responderam confiar menos.

O efeito da moderação das variáveis de confiança na relação entre divulgação da empresa solidária apoiadora e valor doado apresentou os seguintes resultados: variável “confiança causa” com qui-quadrado 8,559 e nível de significância 0,036; variável "confiança total" com qui-quadrado 10,645 e nível de significância 0,014; e a variável “AFECE é confiável" com qui-quadrado 9,560 e nível de significância 0,023, conforme Quadro 41.

Quadro 40 - Efeito da moderação das variáveis de Confiança na relação entre Divulgação de Empresa Solidária apoiadora e Valor doado

\begin{tabular}{|c|c|c|c|c|c|c|c|}
\hline \multirow{3}{*}{ Grupo } & \multirow{3}{*}{ Relação } & \multicolumn{6}{|c|}{ Valor doado } \\
\hline & & \multicolumn{2}{|c|}{ Confiança causa } & \multicolumn{2}{|c|}{ Confiança total } & \multicolumn{2}{|c|}{ AFECE é confiável } \\
\hline & & Qtd & Média & Qtd & Média & Qtd & Média \\
\hline 1 & $\begin{array}{l}\text { Menor Confiança X } \\
\text { Divulga }\end{array}$ & 43 & 56,06 & 30 & 52,50 & 31 & 53,27 \\
\hline 2 & $\begin{array}{l}\text { Menor Confiança X } \\
\text { Não Divulga }\end{array}$ & 39 & 57,60 & 32 & 56,94 & 32 & 56,94 \\
\hline 3 & $\begin{array}{l}\text { Maior Confiança X } \\
\text { Divulga }\end{array}$ & 17 & 68,50 & 30 & 66,67 & 29 & 66,33 \\
\hline 4 & $\begin{array}{l}\text { Maior Confiança X } \\
\text { Não Divulga }\end{array}$ & 21 & 68,50 & 28 & 66,54 & 28 & 66,54 \\
\hline & Total & 120 & & 120 & & 120 & \\
\hline & p-value & \multicolumn{2}{|c|}{0,036} & \multicolumn{2}{|c|}{0,014} & \multicolumn{2}{|c|}{0,023} \\
\hline
\end{tabular}

Para a relação entre a divulgação da empresa solidária apoiadora e valor doado, verificou-se resultado não significativo na análise da hipótese (H2a). Contudo, ao analisar a mediação das variáveis de confiança, os resultados indicam médias maiores para respondentes que indicaram confiar mais em comparação aos que indicam confiar menos.

Realizou-se ainda o teste U de Mann Whitney para identificar o efeito da moderação das variáveis de confiança por pares de grupos de variáveis independentes em relação ao valor doado. Devido à necessidade de evitar o erro tipo 1, que é inflacionar a taxa de erro por realizar várias comparações, utilizou-se a correção de Bonferroni.

Para o efeito da moderação da variável "confiança causa" para a variável "remuneração" foram realizadas seis comparações e a análise foi consubstanciada para o nível de significância de 0,008 . Não se encontrou significância nos resultados: menor confiança e remuneração baixa versus menor confiança e remuneração moderada ( $Z$ de $-1,401$, nível de significância 0,161); menor confiança e remuneração baixa versus menor confiança e remuneração alta $(Z$ de $-0,182$, nível de significância 0,856$)$; menor confiança e remuneração 
baixa versus maior confiança e remuneração baixa/moderada/alta ( $Z$ de $-1,820$, nível de significância 0,069); menor confiança e remuneração moderada versus menor confiança e remuneração alta ( $Z$ de $-1,725$, nível de significância 0,085$)$; menor confiança e remuneração moderada versus maior confiança e remuneração baixa/moderada/alta ( $\mathrm{Z}$ de $-1,168$, nível de significância 0,243); e menor confiança e remuneração alta versus maior confiança e remuneração baixa/moderada/alta ( $Z$ de -2,074, nível de significância 0,038).

Para o efeito da moderação da variável "confiança causa" para a variável "divulgação da empresa solidária apoiadora", foram realizadas três comparações e a análise foi consubstanciada para o nível de significância de 0,016. Não se encontrou significância nos resultados: menor confiança e divulga versus menor confiança e não divulga $(Z$ de $-0,269$, nível de significância 0,788 ); menor confiança e divulga versus maior confiança e divulga/não divulga ( $Z$ de $-2,022$, nível de significância 0,043 ); e menor confiança e não divulga versus maior confiança e divulga/não divulga ( $\mathrm{Z}$ de $-1,847$, nível de significância 0,065 ).

Para o efeito da moderação da variável "confiança total" para a variável "remuneração", foram realizadas dez comparações e a análise foi consubstanciada para o nível de significância de 0,005 . Verificou-se resultado significativo para a relação entre menor confiança e remuneração alta versus maior confiança e remuneração baixa/alta $(Z$ de $-2,906$, nível de significância 0,004), conforme Quadro 42. Para as demais relações, não se encontrou significância nos resultados: menor confiança e remuneração baixa versus menor confiança e remuneração moderada ( $\mathrm{Z}$ de $-1,971$, nível de significância 0,049 ); menor confiança e remuneração baixa versus menor confiança e remuneração alta $(Z$ de $-0,580$, nível de significância 0,562); menor confiança e remuneração baixa versus maior confiança e remuneração baixa/alta ( $Z$ de $-2,255$, nível de significância 0,024$)$; menor confiança e remuneração baixa versus maior confiança e remuneração moderada ( $Z$ de $-1,409$, nível de significância 0,159); menor confiança e remuneração moderada versus menor confiança e remuneração alta ( $Z$ de $-2,674$, nível de significância 0,007); menor confiança e remuneração moderada versus maior confiança e remuneração baixa/alta ( $Z$ de $-0,879$, nível de significância 0,379); menor confiança e remuneração moderada versus maior confiança e remuneração moderada ( $Z$ de $-0,714$, nível de significância 0,475 ); menor confiança e remuneração alta versus maior confiança e remuneração moderada $(Z$ de $-2,115$, nível de significância 0,034); e maior confiança e remuneração baixa/alta versus maior confiança e remuneração moderada ( $\mathrm{Z}$ de $-1,395$, nível de significância 0,163 ). 
Quadro 41 - Relação: Menor Confiança e Remuneração alta X Maior Confiança e Remuneração baixa/alta

\begin{tabular}{|c|l|c|}
\hline Grupo & \multicolumn{1}{|c|}{ Relação } & $\begin{array}{c}\text { Média do valor } \\
\text { doado }\end{array}$ \\
\hline $\mathbf{3}$ & Menor confiança X Remuneração alta & 14,00 \\
\hline 4 OU 6 & Maior confiança X Remuneração baixa/alta & 21,00 \\
\hline \multicolumn{2}{|r|}{$\boldsymbol{p \text { -value }}$} & $\mathbf{0 , 0 0 4}$ \\
\hline
\end{tabular}

Para o efeito da moderação da variável "confiança total" para a variável "divulgação da empresa solidária apoiadora", foram realizadas seis comparações e a análise foi consubstanciada para o nível de significância de 0,008 . Não encontrou-se significância nos resultados: menor confiança e divulga versus menor confiança e não divulga $(Z$ de $-0,638$, nível de significância 0,524$)$; menor confiança e divulga versus maior confiança e divulga $(Z$ de $-2,561$, nível de significância 0,01); menor confiança e divulga versus maior confiança e não divulga ( $Z$ de $-2,460$, nível de significância 0,014$)$; menor confiança e não divulga versus maior confiança e divulga ( $Z$ de $-1,963$, nível de significância 0,05 ); menor confiança e não divulga versus maior confiança e não divulga ( $Z$ de $-1,876$, nível de significância 0,061 ); e maior confiança e não divulga versus maior confiança e não divulga ( $Z$ de $-0,049$, nível de significância 0,961).

Para o efeito da moderação da variável “AFECE é confiável” para a variável "remuneração", foram realizadas quinze comparações e a análise foi consubstanciada para o nível de significância de 0,003. Não se encontrou significância nos resultados: menor confiança e remuneração baixa versus menor confiança e remuneração moderada $(Z$ de 1,374, nível de significância 0,169); menor confiança e remuneração baixa versus menor confiança e remuneração alta ( $Z$ de $-0,388$, nível de significância 0,698); menor confiança e remuneração baixa versus maior confiança e remuneração baixa $(Z$ de $-2,032$, nível de significância 0,042); menor confiança e remuneração baixa versus maior confiança e remuneração moderada ( $Z$ de $-1,773$, nível de significância 0,076); menor confiança e remuneração baixa versus maior confiança e remuneração alta $(Z$ de $-1,907$, nível de significância 0,057); menor confiança e remuneração moderada versus menor confiança e remuneração alta ( $Z$ de $-1,858$, nível de significância 0,063$)$; menor confiança e remuneração moderada versus maior confiança e remuneração baixa $(Z$ de $-1,212$, nível de significância 0,225); menor confiança e remuneração moderada versus maior confiança e remuneração moderada ( $Z$ de $-0,534$, nível de significância 0,593$)$; menor confiança e remuneração moderada versus maior confiança e remuneração alta $(Z$ de $-0,645$, nível de significância 0,519); menor confiança e remuneração alta versus maior confiança e remuneração baixa ( $Z$ de $-2,500$, nível de significância 0,012); menor confiança e remuneração alta versus maior 
confiança e remuneração moderada ( $Z$ de -2,276, nível de significância 0,023); menor confiança e remuneração alta versus maior confiança e remuneração alta $(Z$ de $-2,420$, nível de significância 0,016); maior confiança e remuneração baixa versus maior confiança e remuneração moderada ( $Z$ de $-0,889$, nível de significância 0,374); maior confiança e remuneração baixa versus maior confiança e remuneração alta $(Z$ de $-0,808$, nível de significância 0,419); maior confiança e remuneração moderada versus maior confiança e remuneração alta ( $Z$ de $-0,103$, nível de significância 0,918).

Para o efeito da moderação da variável "AFECE é confiável” para a variável “divulgação da empresa solidária apoiadora”, foram realizadas seis comparações e a análise foi consubstanciada para o nível de significância de 0,008 . Não se encontrou significância nos resultados: menor confiança e divulga versus menor confiança e não divulga $(Z$ de $-0,512$, nível de significância 0,609); menor confiança e divulga versus maior confiança e divulga $(Z$ de -2,348, nível de significância 0,019); menor confiança e divulga versus maior confiança e não divulga ( $Z$ de $-2,392$, nível de significância 0,017$)$; menor confiança e não divulga versus maior confiança e divulga ( $Z$ de $-1,842$, nível de significância 0,065$)$; menor confiança e não divulga versus maior confiança e não divulga ( $Z$ de $-1,876$, nível de significância 0,061 ); e maior confiança e não divulga versus maior confiança e não divulga $(Z$ de 0 , nível de significância 1).

Ao verificar o efeito da moderação das variáveis de confiança na relação entre as variáveis independentes (remuneração e empresa solidária apoiadora) com a variável dependente probabilidade de doar futuramente, apenas as variáveis "confiança causa" e "AFECE é confiável” apresentaram significância quando ocorre a divulgação da empresa solidária apoiadora, com nível de significância 0,021 e $0,098^{11}$, conforme Quadro 43. Os demais resultados não foram significativos: confiança causa e remuneração (nível de significância 0,341); confiança total e remuneração (nível de significância 0,620); confiança total e divulgação (nível de significância 0,269); e AFECE é confiável e remuneração (nível de significância 0,711).

\footnotetext{
${ }^{11}$ Os resultados são significativos ao nível de confiança de $90 \%$ e valor crítico 0,1 .
} 
Quadro 42 - “Confiança causa" e "AFECE é confiável” na relação entre Divulgação da empresa solidária apoiadora e Probabilidade de doar futuramente (frequências)

\begin{tabular}{|c|c|c|c|c|c|c|c|c|}
\hline \multirow{2}{*}{$\begin{array}{l}\text { Probabilidade de doação } \\
\text { futura }\end{array}$} & $\mathbf{A}$ & B & $\mathbf{A}$ & B & $\mathbf{A}$ & B & $\mathbf{A}$ & B \\
\hline & \multicolumn{2}{|c|}{$\begin{array}{l}\text { Menor confiança } \\
\text { e divulga }\end{array}$} & \multicolumn{2}{|c|}{$\begin{array}{l}\text { Menor confiança } \\
\text { e não divulga }\end{array}$} & \multicolumn{2}{|c|}{$\begin{array}{l}\text { Maior confiança } \\
\text { e divulga }\end{array}$} & \multicolumn{2}{|c|}{$\begin{array}{l}\text { Maior confiança } \\
\text { e não divulga }\end{array}$} \\
\hline Nenhuma probabilidade & 7 & 8 & 6 & 8 & 3 & 2 & 4 & 2 \\
\hline Baixíssima probabilidade & 5 & 4 & 3 & 2 & 1 & 2 & 2 & 3 \\
\hline Baixa probabilidade & 9 & 5 & 8 & 7 & 0 & 4 & 3 & 4 \\
\hline Moderada probabilidade & 9 & 8 & 12 & 7 & 3 & 4 & 5 & 10 \\
\hline Alta probabilidade & 9 & 4 & 7 & 5 & 6 & 11 & 2 & 4 \\
\hline Altíssima probabilidade & 1 & 0 & 3 & 2 & 0 & 1 & 4 & 5 \\
\hline Doação certa & 3 & 2 & 0 & 1 & 4 & 5 & 1 & 0 \\
\hline Total & 43 & 31 & 39 & 32 & 17 & 29 & 21 & 28 \\
\hline p-value A & 0,098 & & & & -value B & 0,021 & & \\
\hline
\end{tabular}

Legenda: A: Confiança causa B: AFECE é confiável

Para a relação entre divulgar a remuneração do dirigente e doação futura, em que o resultado da hipótese (H1b) não foi significativo, também quando analisado considerando o efeito moderador das variáveis de confiança, não houve significância. Na relação entre divulgação da empresa solidária apoiadora e doação futura, o resultado da análise da hipótese (h2b) foi significativo e essa associação é confirmada quando considerada a moderação das variáveis "confiança na causa" e "AFECE é confiável”. 


\section{CONCLUSÕES}

A presente pesquisa teve como objetivo verificar qual o efeito que a divulgação de empresas solidárias apoiadoras e da remuneração de dirigentes de OSFL possui na decisão sobre o volume de contribuição e na propensão de doar futuramente por parte do doador individual. Para realização da investigação, a partir de estudo teórico sobre o tema, enuciou-se como tese a ser defendida que o disclosure voluntário de empresa solidária apoiadora e da remuneração pela OSFL possui efeito positivo na propensão de doação futura e no volume de contribuição na decisão do doador individual.

Para consecusão do objetivo apresentado e defesa da tese, desenvolveu-se o levantamento bibliográfico sobre OSFL, disclosure das organizações em geral e das instituições do setor sem fins lucrativos, divulgação de remuneração em OSFL e influência social. A elaboração do referencial teórico direcionou a construção de três hipóteses de pesquisas, cada uma subdividida em duas hipóteses para contemplar as duas variáveis dependentes da pesquisa.

A primeira hipótese da pesquisa relaciona a variável independente "remuneração do dirigente" com as variáveis dependentes "valor doado" e "probabilidade de doar futuramente" (H1a e H1b), considerando que, quanto maior o valor de remuneração do dirigente divulgado pela OSFL, menor o volume de contribuição e maior a probabilidade de doar futuramente por parte do doador individual.

Como resultados das análises em relação ao valor doado, não foi possível identificar diferenças significativas para os diferentes grupos de remuneração do dirigente (sem informação, remuneração baixa, remuneração moderada e remuneração alta) determinadas pelo estudo. Também em análise qualitativa dos resultados, não foi possível identificar diferenças de média do valor doado superiores a $10 \%$ entre os grupos.

Em relação à probabilidade de o doador individual doar futuramente, não se verificou associação significativa com a variável remuneração do dirigente. Denotam-se indícios de que as variáveis moderadoras de confiança tenham reduzido o efeito adverso da divulgação da remuneração do dirigente.

A segunda hipótese do estudo relaciona a variável independente "empresa solidária apoiadora" com as variáveis dependentes "valor doado" e "probabilidade de doar futuramente (H2a e H2b) e estabelecem que, as OSFL que divulgam a empresa solidária apoiadora recebem maior volume de recursos dos doadores individuais e estes são mais propensos a doar futuramente. Para a variável valor doado, os resultados não foram significantes. 
Os resultados para a variável probabilidade de doar futuramente demonstraram que existe associação significativa com a divulgação da empresa solidária apoiadora pela OSFL, ou seja, existe diferença significativa na decisão em doar futuramente por parte do doador individual, comparando-se a OSFL que divulga a empresa solidária apoiadora com a OSFL que não divulga.

Qualitativamente, observa-se um percentual aproximado de $28 \%$ a mais de respostas positivas para a doação futura (probabilidade alta, probabilidade altíssima e doação certa) para quando a OSFL faz a divulgação da empresa solidária apoiadora. Além disso, também quando analisadas em conjunto, as respostas mais negativas (probabilidade baixa, probabilidade baixíssima e nenhuma probabilidade) foram $44 \%$ menos presentes quando a OSFL divulga a empresa solidária apoiadora do que quando não divulga.

Há indícios, portanto, de que divulgar a empresa solidária apoiadora por parte da OSFL gera o compliance sobre o doador, fazendo que haja maior propensão de doação futuramente. Isto corrobora com o apresentado por Cialdini e Trost (1998), com evidências de que houve uma resposta por parte do doador da probabilidade de doar futuramente em virtude de um modo particular de comunicação explícita, a solicitação de doação pela OSFL, ocorrendo a forma de influência social pelo compliance de direcionamento por figura de autoridade legítima exercida pela empresa solidária apoiadora.

Os resultados também vão ao encontro dos achados de Trussel e Parsons (2007) e de Portulhak et al. (2017) que encontraram relação positiva entre reputação da entidade e doações ou doações futuras, apenas a forma de capturar a reputação da entidade foi diferente, em que os estudos realizaram por meio de categorização das demonstrações contábeis das OSFL e a presente pesquisa pela influência social da empresa solidária apoiadora.

A terceira hipótese (H3a e H3b) busca identificar se o efeito interativo das variáveis independentes pela divulgação da "remuneração do dirigente" e da "empresa solidária apoiadora" sobre o montante de contribuição e a probabilidade de doar futuramente pelo doador individual, não encontrou resultados significativos.

Quando se analisou as variáveis de controle com o efeito do disclosure da remuneração do dirigente por nível de valor divulgado, conformou-se correlação positiva e significativa entre o valor doado e a confiança na OSFL e na causa por parte do doador.

Ao analisar os grupos separados pela divulgação ou não da empresa solidária apoaidora, verificou-se associação significativa positiva entre o valor doado e a confiança na OSFL e na causa, bem como com a escolaridade dos respondentes. Finalmente, a análise dos grupos separados pela interação entre divulgação da remuneração do dirigente e da empresa 
solidária apoiadora, comprovou-se correlação positiva e significativa entre valor doado e confiança na causa e na OSFL.

De modo geral, este estudo contribui para ampliar os conhecimentos sobre o setor sem fins lucrativos no Brasil, pois agrega análises sobre o disclosure voluntário em relação à remuneração do dirigente, ainda tema pouco estudado no país para OSFL. Compreende-se que a principal relevância do estudo está na abordagem da divulgação da empresa solidária apoiadora como fonte de autoridade legítima da OSFL e do efeito de compliance sobre o doador individual, visto a confirmação parcial da tese enunciada na presente pesquisa, de que o disclosure voluntário da empresa solidária apoiadora possui efeito positivo na propensão de doação futura do doador individual.

Uma das limitações para realização de estudos na área é a escassez de informações públicas disponíveis com dados contábeis ou de outras informações financeiras e não financeiras das OSFL, seja por meio dos sites das respectivas organizações, como por agências de divulgação conjunta de informação.

Como muitos dos estudos sobre contribuição dos doadores, este é primeiramente limitado pela natureza endógena do ato de doar. Além disso, Cruz (2010) relata que é difícil prever o comportamento dos doadores brasileiros no que se refere ao uso das comunicações emanadas da contabilidade e Zittei et al. (2016) relata a falta de evidenciação contábil pelas OSFL no país. Salienta-se a relevância do desenvolvimento de ferramentas que auxiliem na divulgação de informações padronizadas das OSFL, principalmente para o atendimento das necessidades do doador individual.

Outro ponto foi a seleção da OSFL feita por conveniência, pois era necessário uma instituição que não fosse amplamente conhecida, mas que tivesse uma estrutura mínima que permitisse atribuir remuneração ao dirigente e que fosse favorável à parceria no estudo. Muitos respondentes atribuíram como fator motivacional para a decisão a causa em prol da qual a organização atua. Neste sentido, existe a possibilidade de, para OSFL atuantes em prol de causas diferentes, a decisão do doador também seja diferente, da mesma forma que os resultados da pesquisa.

Em relação à análise da variável "valor doado", o fato de ser uma pesquisa e haver a necessidade de, antes de participar do estudo, o respondente assinar um termo de consentimento que detalha se tratar de uma pesquisa de doutorado, podendo isso gerar o compliance sobre o doador e levando-o a doar maior valor do que doaria se não se tratasse de pesquisa de doutoramento e, podendo gerar a confiança na OSFL, que não ocorreria caso o 
mesmo recebesse um pedido de doação. Portanto, compreende-se que, a forma como a organização faz o pedido de doação também influencia o comportamento do doador.

Houve limitação em relação à viabilidade financeira, pois devido à necessidade de um número mínimo de respondentes, o valor do crédito ao participante foi limitado em relação ao tempo para responder ao estudo. Também, a aleatorização controlada, que faz com que haja um número moderado de casos. Apesar de recomendado por Shadish et. al (2002), acaba-se direcionando para os casos sequenciais que ainda não tiveram número suficiente de respostas.

A padronização das respostas abertas para os fatores influenciadores de decisão de doação também restringe a análise, pois apesar de facilitá-la, uma avaliação qualitativa das respostas poderia aprofundar mais a questão sobre como o doador toma a sua decisão. Além disso, de modo geral, verificou-se nas respostas dos participantes às questões correspondentes às variáveis de controle do estudo, tendência de centralidade nas respostas.

A limitação também ocorre pela escolha de uma empresa solidária apoiadora. Estudos com outras empresas podem trazer resultados diferentes, bem como pode haver a necessidade de verificar se os atributos (moral e ética) da empresa solidária apoiadora são considerados pelos doadores.

Como sugestões para futuras pesquisas, corrobora-se a necessidade de buscar reduzir o efeito do compliance exercido por se tratar de uma pesquisa de doutoramento, utilizando outras formas de coleta de dados, como, por exemplo, utilizar meios e formas disponíveis de solicitação de recursos da própria OSFL. Além disso, recompensar valores maiores e atividades desenvolvidas previamente à doação podem reduzir o efeito declarado pelos participantes de que o dinheiro não fazia parte do orçamento ou que o valor era baixo.

Outra oportunidade de pesquisa futura é a análise comparativa entre empresas solidária apoiadoras diferentes divulgadas, para verificar se os resultados variam apenas devido à divulgação da empresa solidária apoiadora ou se é decorrente dessa empresa ter responsabilidade social e reputação ética e moral sob a percepção do doador. Além disso, sugestão adicional considera futuramente a realização de estudos sobre a decisão de doação utilizando dados contábeis, bem como informações financeiras e não financeiras, se passíveis de serem obtidos publicamente em sites de OSFL ou de agências que divulguem conjuntamente informações de OSFL. 


\section{REFERÊNCIAS}

Aboody, D., \& Kasznik, R. (2000). CEO stock option awards and the timing of corporate voluntary disclosures. Journal of Accounting and Economics, 29(1), 73-100.

Alford, A., Jones, J., Leftwich, R., \& Zmijewski, M. (1993). The relative informativeness of accounting disclosures in different countries. Journal of Accounting Research, 183-223.

Alves, C. V. O. (2005). Organizações da sociedade civil de interesse público e termos de parceria: um estudo sobre o processo de avaliação de resultados dos projetos sociais desenvolvidos com recursos governamentais no Brasil. Universidade de São Paulo.

Andreoni, J. (1990). Impure Altruism and Donations to Public Goods: A Theory of WarmGlow Giving. The Economic Journal, 100(401), 464-477.

Atan, R., Zainon, S., \& Wah, Y. B. (2012). Quality Information by Charity Organizations and its Relationship with Donations. Recent Advances in Business Administration Quality, $118-123$.

Baber, W. R., Daniel, P. L., \& Roberts, A. A. (2002). Compensation to Managers of Charitable Organizations: An Empirical Study of the Role of Accounting Measures of Program Activities. The Accounting Review, 77(3), 679-693. http://doi.org/dx.doi.org/10.2308/accr.2002.77.3.679

Ball, R., Kothari, S. P., \& Robin, A. (2000). The effect of international institutional factors on properties of accounting earnings. Journal of Accounting and Economics, 29(1), 1-51.

Ballantine, J., Forker, J., \& Greenwood, M. (2008). The governance of CEO incentives n english NHS hospital trusts. Financial Accountability \& Management, 24(November), $385-411$.

Ballou, J. P., \& Weisbrod, B. a. (2003). Managerial rewards and the behavior of for-profit, governmental, and nonprofit organizations: evidence from the hospital industry. Journal of Public Economics, 87(9-10), 1895-1920. http://doi.org/10.1016/S0047-2727(01)00224-9

Balsam, S., \& Harris, E. E. (2014). The Impact of CEO Compensation on Nonprofit Donations. The Accounting Review, 89(2), 425-450. http://doi.org/10.2308/accr-50631

Balser, D., \& McClusky, J. (2005). Managing stakeholder relationships and nonprofit organization effectiveness. Nonprofit Management and Leadership, 15(3), 295-315. http://doi.org/10.1002/nml.70

Barragato, C. A. (2002). Linking For-Profit and Nonprofit Executive Compensation: Salary Composition and Incentive Structures in the U . S . Hospital Industry, 13(3).

Beaver, W. H. (1980). Financial reporting: an accounting revolution. In T. Mouck (Ed.), The "revolution" in financial reporting theory: a Kuhnian interpretation (2nd ed.). Englewood Cliffs: Prentice Hall.

Ben-Ner, a., Ren, T., \& Paulson, D. F. (2010). A Sectoral Comparison of Wage Levels and Wage Inequality in Human Services Industries. Nonprofit and Voluntary Sector Quarterly, 40(4), 608-633. http://doi.org/10.1177/0899764010365012

Berle, A. A., \& Means, G. C. (1932). The Modern Corporation and Private Property. New Brunswick and New Jersey: Transaction Publishers. Retrieved from https://books.google.com.br/books?hl=en\&lr=\&id=mLdLHhqxUb4C\&oi=fnd\&pg=PR8\&d $\mathrm{q}=$ berle + and + means $+1932 \&$ ots $=$ QChWHMLc6U\&sig $=$ YHzTzT1FPp9AAXGnEibDyv1Q $\mathrm{QdA \#}=$ onepage $\& \mathrm{q}=$ berle and means $1932 \& \mathrm{f}=$ false 
Bettiol Junior, A. (2005). Formação e destinação do resultado em entidades do terceiro setor: um estudo de caso. Universidade de São Paulo.

Beyer, A., Cohen, D. A., Lys, T. Z., \& Walther, B. R. (2010). The financial reporting environment: Review of the recent literature. Journal of Accounting and economics2, 50(2), 296-343.

Bogart, W. T. (1995). Accountability and nonprofit organizations: An economic perspective. Nonprofit Management \& Leadership, 6(2), 157-170.

Brasil. Decreto $\mathrm{n}^{0} 50.157$ de 02 de maio de 1961 da Presidência da República (1961). Retrieved from http://www.planalto.gov.br/ccivil_03/decreto/1950-1969/d50517.htm

Brasil. Decreto n. 2.536, de 06/04/1998. (1998). Dispõe sobre a concessão do certificado de entidades de fins filantrópicos a que se refere o inciso IV do art. 18 da lei n. 8.742, de 7 de dezembro de 1993, e dá outras providências. Retrieved from http://www.planalto.gov.br/CCIVIL/decreto/d2536.htm

Brasil. Lei 9.637 de 15 de maio de 1998 (1998). Brasília: Dispõe sobre a qualificação de entidades como organizações sociais, a criação do Programa Nacional de Publicização, a extinção dos órgãos e entidades que menciona e a absorção de suas atividades por organizações sociais, e dá outras providências.

Brasil. Lei no 9.790 de 23 de março de 1999 da Presidência da República (1999). Retrieved from http://www.planalto.gov.br/ccivil_03/leis/19790.htm

Brasil. Lei 10.406 - Lei de Introdução ao Código Civil Brasileiro (2002). Retrieved from http://www.planalto.gov.br/ccivil_03/leis/2002/110406.htm

Brasil. Lei 10.637 - Lei da não cumulatividade na cobrança da contribuição para os Programas de Integração Social (PIS) e de Formação do Patrimônio do Servidor Público (Pasep) (2002). Retrieved from http://www.planalto.gov.br/ccivil_03/leis/2002/110637.htm

Brasil. Lei 10.825 de 22 de dezembro de 2003 (2003). Brasília/DF: Dá nova redação aos arts. 44 e 2.031 da Lei no 10.406, de 10 de janeiro de 2002, que institui o Código Civil.

Brasil. Lei $\mathrm{n}^{0} 12.101$ de 27 de novembro de 2009 da Presidência da República (2009). Retrieved from http:/www.planalto.gov.br/ccivil_03/_ato2007-2010/2009/lei/112101.htm

Brasil. Lei $\mathrm{n}^{\mathrm{o}} 12.868$ de 15 de Outubro de 2013 da Presidência da República (2013). Retrieved from http://www.planalto.gov.br/ccivil_03/_ato2011-2014/2013/Lei/L12868.htm

Brasil. Decreto $n^{0} 8242$ de 23 de maio de 2014 do Poder Executivo (2014). Retrieved from http://www.confenact.org.br/wp-content/uploads/2014/05/Decreto-n\%C2\%BA-8242-2014Regulamenta\%C3\%A7\%C3\%A3o-Lei-12.101-2009-CEBAS.pdf

Brasil. Lei 13.109 de 31 de julho de 2014 (2014). Brasília: Estabelece o regime jurídico das parcerias entre a administração pública e as organizações da sociedade civil, em regime de mútua cooperação, para a consecução de finalidades de interesse público e recíproco, mediante a execução de atividades ou de projet.

Brasil. Lei 13.204/2015 de 14 de dezembro de 2015 (2015). Brasília.

Brito, C. A. O., \& Cardoso, K. C. R. M. (2010). Gestão de custos: uma ferramenta administrativa nas entidades do Terceiro Setor. Sitientibus, 43, 113-123.

Bromley, D. B. (2002). An Examination of Issues That Complicate the Concept of Reputation in Business Studies. International Studies of Management \& Organization, 32(3), 65-81. 
Bryant, W. K., Jeon-Slaughter, H., Kang, H., \& Tax, A. (2003). Participation in philanthropic activities: Donating money and time. Journal of Consumer Policy, 26(1), 43-73.

Carneiro, A. D. F., Oliveira, D. D. L., \& Torres, L. C. (2011). Accountability e Prestação de Contas das Organizações do Terceiro Setor: Uma Abordagem à Relevância da Contabilidade. Revista Sociedade, Contabilidade E Gestão, 6(2), 90-105.

CFC, C. F. de C. Norma Brasileira de Contabilidade NBC T 10.19 - Entidade sem finalidades de lucros (1999).

CFC, C. F. de C. (2008). Manual de Procedimentos Contábeis e Prestação de Contas das entidades de interesse social. (CFC, Ed.) (2nd ed.). Brasília. Retrieved from www.cfc.org.br/uparq/Manual_procedimentos2008.pdf.

Chen, X., Ren, T., \& Knoke, D. (2014). Do Nonprofits Treat Their Incentive Pay and Health Benefits, 24(3), 285-306. http://doi.org/10.1002/nml

Cialdini, R., \& Trost, M. (1998). Social Influence: social norms, conformity and compliance. In D. T. Gilbert, S. T. Fiske, \& G. Lindzey (Eds.), The Handbook of Social Psycology (4th ed., pp. 151-1922). New York: McGraw-Hill.

Ciconello, A., \& Moraes, M. (2014). ONGs no Brasil: As ONGs podem remunerar seus dirigentes? Retrieved October 2, 2014, from http://www.abong.org.br/ongs.php?id=858

Cnaan, R. A., Jones, K., Dickin, A., \& Salomon, M. (2011). Nonprofit watchdogs: Do they serve the average donor? Nonprofit Management and Leadership, 21(4), 381-397. http://doi.org/10.1002/nml.20032

Collins, D. W., \& Kothari, S. P. (1989). An analysis of intertemporal and cross-sectional determinants of earnings response coefficients. Journal of Accounting and Economics, 11(2-3), 143-181.

Consoni, S. (2014). Divulgação voluntária e sua relação com gerenciamento de resultados contábeis. Universidade Federal do Paraná.

Core, J. E., Guay, W. R., \& Verdi, R. S. (2006). Agency problems of excess endowment holdings in not-for-profit firms. Journal of Accounting and Economics, 41(3), 307-333. http://doi.org/10.1016/j.jacceco.2006.02.001

CPC. Pronunciamento Conceitual Básico - Estrutura conceitual para a elaboração e apresentação das demonstrações contábeis., Comitê de Pronunciamentos Contábeis (2008). Retrieved from http://www.cpc.org.br/pdf/pronunciamento_conceitual.pdf

Cruz, C. M., \& Estraviz, M. (2003). Captação de diferentes recursos para Organizações sem fins lucrativos (2nd ed.). São Paulo: Global.

Cruz, C. V. O. A. (2010). A relevância da informação contábil para os investidores sociais privados de entidades do terceiro setor no Brasil: uma investigação empírica. Universidade de São Paulo. Universidade de São Paulo.

Cruz, C. V. O. A., Corrar, L. J., \& Slomski, V. (2008). Efeitos da Divulgação de Informações Contábeis Econômicas sobre as Doações Individuais para Entidades do Terceiro Setor: Um Estudo Experimental com Alunos de Ciências Contábeis. In XXXII Encontro da Associação Nacional de Pós-graduação e Pesquisa em Administração - EnANPAD (pp. 114). Rio de Janeiro.

Cruz, A. P. C. da, Espejo, M. M. D. S. B., Gassner, F. P., \& Walter, S. A. (2010). Uma Análise do Desenvolvimento do Campo de Pesquisa em Contabilidade Gerencial sob a 
Perspectiva Colaborativa Mapeada em Redes Sociais. Revista Contabilidade Vista \& Revista, 21(2), 95-120.

Cunha, J. H. D. C., \& Matias-Pereira, J. (2012). Captação de recursos no terceiro setor: fatores estratégicos para divulgação de informações. Revista Contemporânea de Contabilidade, 9(18), 83-102. http://doi.org/10.5007/2175-8069.2012v9n18p83

Darrough, M. N. (1993). Disclosure policy and competition: Cournot vs. Bertrand. Accounting Review, 534-561.

Darrough, M. N., \& Stoughton, N. M. (1990). Financial disclosure policy in an entry game. Journal of Accounting and Economics, 12(1), 219-243.

Davidoff, L. L. (2006). Introdução à Psicologia. São Paulo: Pearson.

Demsetz, H., \& Lehn, K. (1985). The structure of corporate ownership: causes and consequences. Journal of Political Economy, 93(6), 1155-1177. http://doi.org/10.1086/261354

Deutsch, M., \& Gerard, H. B. (1955). A study of normative and informational social influences upon individual judgment. The Journal of Abnormal and Social Psychology, $51(3), 629$.

Dowling, G. (2004). Corporate reputations: Should you compete on yours? California Management Review, 46(3), 19-36.

Dye, R. A. (2001). An evaluation of "essays on disclosure" and the disclosure literature in accounting. Journal of Accounting and Economics, 32(1), 181-235.

Easton, P. D., \& Zmijewski, M. E. (1989). Cross-sectional variation in the stock market response to accounting earnings announcements. Journal of Accounting and Economics, $11(2-3), 117-141$.

Falconer, A. P. (1999). A promessa do terceiro setor. Universidade de São Paulo.

Fama, E. F., \& Jensen, M. C. (1983). Separation of Ownership and Control. Journal of Law and Economics, 26(2), 301-325.

Feltham, G. A., \& Xie, J. Z. (1992). Voluntary financial disclosure in an entry game with continua of types. Contemporary Accounting Research, 9(1), 46-80.

Fernandes, R. C. (1994). Privado porém público: o terceiro setor na América Latina. Rio de Janeiro: Relume-Dumará.

Fischer, R. M., \& Falconer, A. P. (1998). Desafios da Parceria Governo Terceiro Setor. Revista de Administração, 33(1), 12-19.

Fletcher, A., Guthrie, J., Steane, P., Roos, G., \& Pike, S. (2003). Mapping stakeholder perceptions for a third sector organization. Journal of Intellectual Capital, 4(4), 505-527. http://doi.org/10.1108/14691930310504536

Frumkin, P., \& Keating, E. K. (2010). The price of doing good: Executive compensation in nonprofit organizations. Policy and Society, 29(3), 269-282. http://doi.org/10.1016/j.polsoc.2010.07.004

Galle, B., \& Walker, D. I. (2013). The problem of nonprofit executive pay?: evidence from U.S. colleges and universities. Boston, MA.

Gandia, J. L. (2011). Internet Disclosure by Nonprofit Organizations: Empirical Evidence of 
Nongovernmental Organizations for Development in Spain. Nonprofit and Voluntary Sector Quarterly, 40(1), 57-78. http://doi.org/10.1177/0899764009343782

Gigler, F. (1994). Self-enforcing voluntary disclosures. Journal of Accounting Research, 224240.

Glaeser, E. L. (2007). The governance of not-for-profit organizations. University of Chicago Press.

Gordon, T. P., \& Khumawala, S. B. (1999). The demand for not-for-profit financial statements: A model of individual giving. Journal of Accounting Literature, 18, 31-56.

Gordon, T. P., Knock, C. L., \& Neely, D. G. (2009). The role of rating agencies in the market for charitable contributions: An empirical test. Journal of Accounting and Public Policy, 28(6), 469-484.

Gounaris, S. (2005). Measuring service quality in b2b services: an evaluation of the SERVQUAL scale vis-à-vis the INDSERV scale. Journal of Services Marketing, 19(6), 421-435. http://doi.org/10.1108/08876040510620193

Grasse, N., Davis, T., \& Ihrke, D. (2014). Understanding the compensation of nonprofit executive directors: Examining the influence of performance and organizational characteristics. Nonprofit Management \& Leadership, 24(3), 377-398. http://doi.org/10.1002/nml.21099

Gray, S. R., \& Benson, P. G. (2003). Determinants of Executive Compensation in Small Business Development Centers, 13(3), 213-227.

Grossman, S. J., \& Hart, O. D. (1983). An Analysis of the Principal-Agent Problem. The Econometric Society, 51(1), 7-45. Retrieved from http://www.jstor.org/stable/1912246

Hall, H. (2004). Gender differences in giving: Going, going, gone? New Directions for Philanthropic Fundraising, 43, 71-81.

Handy, F., \& Katz, E. (1998). The Wage Differential between Nonprofit Institutions and Corporations: Getting More by Paying Less? Journal of Comparative Economics, 26, 246-261.

Handy, F., Mook, L., Ginieniewicz, J., \& Quarter, J. (2007). The Moral High Ground: Perceptions of Wage Differentials Among Executive Directors of Canadian Nonprofits. The Philanthropist, 21(2), 109-127.

Handy, F., Seto, S., Wakaruk, A., Mersey, B., Mejia, A., \& Copeland, L. (2010). The Discerning Consumer: Is Nonprofit Status a Factor? Nonprofit and Voluntary Sector Quarterly, 39(5), 866-883. http://doi.org/10.1177/0899764010362113

Hansmann, H. (1981). Nonprofit Enterprise in the Performing Arts. The Bell Journal of Economics, 12(2), 341-361. http://doi.org/10.2307/3003560

Hansmann, H. (1987a). Economic theories of nonprofit organization. In The nonprofit sector: A research handbook (pp. 27-42). http://doi.org/10.1007/978-1-4615-0131-2_16

Hansmann, H. (1987b). The Effect of Tax Exemption and other Factors on the market share of Nonprofit versus For-Profit Hirms. National Tax Journal, XL, 71-82.

Healy, P. M., \& Palepu, K. G. (1993). The effect of Firms' Financial Diclosure Strategies on Stock Prices. Accounting Horizons, 7(1), 1-11.

Healy, P. M., \& Palepu, K. G. (1995). The challenges of investor communication The case of 
CUC International. Journal of Financial Economics', 38(2), 111-140.

Healy, P. M., \& Palepu, K. G. (2001). Information asymmetry, corporate disclosure, and the capital markets: A review of the empirical disclosure literature. Journal of Accounting and Economics, 31(1-3), 405-440. http://doi.org/10.1016/S0165-4101(01)00018-0

Herrero, G. de la F., Cruz, N. M., \& Merino, E. R. (2002). The " non residual claim problem " in non-profit organizations. The case of NGODs in Spain. In 6th Annual Conference of International Society for New Institutional Economics (pp. 1-51). Cambridge, MA.

Hipólito, J. A. M. (2004). Recompensas em Organizações que atuam no Terceiro Setor: análise a partir de seus pressupostos orientadores. Universidade de São Paulo.

Hume, C., \& Hume, M. (2008). The strategic role of knowledge management in nonprofit organisations. International Journal of Nonprofit and Voluntary Sector Marketing, 13(2), 129-140. http://doi.org/10.1002/nvsm.316

IBGE. (2010). As Fundações Privadas e Associações sem Fins Lucrativos no Brasil. Rio de Janeiro.

Retrieved

from

http://www.ibge.gov.br/home/estatistica/economia/fasfil/2010/default.shtm

Idis, I. para o desenvolvimento do investimento social, \& Gallup, I. (2015). Pesquisa Doação Brasil.

IPEA, I. de P. E. A. (2008). As fundações privadas e associações sem fins lucrativos no Brasil 2005. Estudos E Pesquisas Informação Econômica, (8).

Jensen, M. C., \& Meckling, W. H. (1976). Theory of the Firm: Managerial Behavior , Agency Costs and Ownership Structure. Journal of Financial Economics, 3, 305-370.

Jin, C.-H., \& Yeo, H.-C. (2011). Satisfaction, corporate credibility, CEO reputation and leadership effects on public relationships. Journal of Targeting, Measurement and Analysis for Marketing, 19(2), 127-140. http://doi.org/10.1057/jt.2011.10

Jones, A., \& Posnett, J. (1991). Charitable donations by UK households: evidence from the Family Expenditure Survey. Applied Economics, 23(2), 343-351.

Kanitz, S. (2015). Terceiro Setor no Brasil | Terceiro Setor Online. Retrieved October 31, 2015, from http://www.filantropia.org/OqueeTerceiroSetor.htm

Keller, K. L. (2013). Strategic Brand Management (4th ed.). London: Pearson Education. Retrieved from http://www.kvimis.co.in/sites/kvimis.co.in/files/ebook_attachments/Keller Strategic Brand Management.pdf

Kerlinger, F. N. (1979). Behavioral research: A conceptual approach (3rd ed.). New York: Harcourt School.

Khumawala, S. B., \& Gordon, T. P. (1997). Bridging the credibility of GAAP: Individual donors and the new accounting standards for nonprofit organizations. Accounting Horizons, 11(3), 45.

Klick, J., \& Sitkoff, R. H. (2008). Agency Costs, Charitable Trusts, and Corporate Control: Evidence from Hershey's Kiss-Off. Columbia Law Review, 108(4), 749-838.

Krashinsky, M. (1997). Stakeholder theories of the non-profit sector: One cut at the economic literature. Voluntas, 8(2), 149-161. http://doi.org/10.1007/BF02354192

Kumar, S. (1995). O gerenciamento da accountability em ONGs. In M. da G. R. NEVES \& D. M. COSTA (Eds.), Gênero e Ong's: Propostas para o fortalecimento institucional. Rio de 


\section{Janeiro: IBAM/ ENSUR/NEMPP.}

Leete, L. (2006). Work in the nonprofit sector. In W. W. Powell \& R. Steinberg (Eds.), The Nonprofit Sector: A Research Handbook (2nd ed., pp. 159-179). New Haven and London: Yale University Press. Retrieved from $\mathrm{http} / / /$ books.google.com.br/books?hl=en\&lr=\&id=ligvL-

cLFIEC\&oi=fnd\&pg=PA159\&dq=leete+2006\&ots=A4gQ9VdBUs\&sig=UfzUF5LNBwFl OjdPyttZKrNfAoo\#v=onepage \&q\&f=false

Leftwich, R. (1980). Market failure fallacies and accounting information. Journal of Accounting and Economics, 2(3), 193-211.

Leuz, C., \& Wysocki, P. D. (2007). Economic consequences of financial reporting and disclosure regulation: A review and suggestions for future research. Retrieved from http://ssrn.com/abstract $=1105398$

Libby, R., Bloomfield, R., \& Nelson, M. W. (2002). Experimental research in financial accounting, 27, 775-810.

Lima, E. M. (2009). Análise comparativa entre o índice de disclosure e a importância atribuída por stakeholders a informações consideradas relevantes para fins de divulgação em IES filantrópicas no Brasil: uma abordagem da teoria da divulgação. Universidade de São.

Lopes, A. B., \& de Alencar, R. C. (2010). Disclosure and cost of equity capital in emerging markets: The Brazilian case. International Journal of Accounting, 45(4), 443-464. http://doi.org/10.1016/j.intacc.2010.09.003

Mañas, A. V., \& Medeiros, E. E. (2012). Terceiro Setor : Um Estudo Sobre a sua Importância no Processo de Desenvolvimento Socio-Econômico. Perspectivas Em Gestão \& Conhecimento, 2(2), 15-29.

Manny, J. S. (2007). Nonprofit Payments to Insiders and Outsiders: Is the Sky the Limit? Fordham Law Reviem, 76(2), 735-763.

McClelland, R., \& Brooks, A. C. (2004). What is the real relationship between income and charitable giving? Public Finance Review, 32(5), 483-497.

Mcdougle, L. M., \& Handy, Fe. (2014). The Influence of Information on Donor Decision Making, 24(4). http://doi.org/10.1002/nml

Mckeever, B. S., \& Pettijohn, S. L. (2014). The Nonprofit Sector in Brief 2014 (Vol. 2007). Retrieved from http://www.urban.org/UploadedPDF/413277-Nonprofit-Sector-in-Brief2014.pdf

Mesch, D. J., Rooney, P. M., Chin, W., \& Steinberg, K. S. (2002). Race and gender differences in philanthropy: Indiana as a test case. New Directions for Philanthropic Fundraising, 37, 65-77.

Michener, H. A. (2005). Psicologia Social. São Paulo: Thomson.

Milani Filho, M. A. F. (2008). Transparência e Opacidade no Terceiro Setor : A Divulgação Financeira de Organizações Filantrópicas. In XV Congresso Brasileiro de Custos (pp. 1$11)$.

Milgrom, P. R. (1981). Good news and Bad News: Representation Theorems and Applications. Bell Journal of Economics, 12(2), 380-391. http://doi.org/10.2307/3003562 
Milgrom, P., \& Roberts, J. (1992). Economics, Organization and Management (1 ed). Englewood Cliffs: Prentice-Hall.

Miller, G., \& Piotroski, J. (2000). The role of disclosure for high book-to-market firms.

Miller, J. L. (2002). The Board as a Monitor of Organizational Activity. Nonprofit Management \& Leadership, 12(4), 429-450.

Mindlin, S. E. (2009). A governança de fundações e institutos empresariais: um estudo exploratório. Universidade de São Paulo.

Mobiliza. (2016). Os dados da pesquisa Doação Brasil estão aí. E agora? Retrieved September 20, 2016, from http://www.mobilizaconsultoria.com.br/os-dados-da-pesquisa-doacaobrasil-estao-ai-e-agora/

Moore, M. H. (2003). The Public Value Scorecard: A Rejoinder and an Alternative to "Strategic Performance Measurement and Management in Non-Profit Organizations" by Robert Kaplan. Hauser Center for Nonprofit Organizations. Cambridge, United Kingdom. Retrieved from http://nvs.sagepub.com/cgi/doi/10.1177/0899764007300407

Newman, P., \& Sansing, R. (1993). Disclosure policies with multiple users. Journal of Accounting Research, 92-112.

Nikolova, M. (2013). Principals and Agents: An Investigation of Executive Compensation in Human Service Nonprofits. VOLUNTAS: International Journal of Voluntary and Nonprofit Organizations, 25(3), 679-706. http://doi.org/10.1007/s11266-013-9358-5

Okten, C., \& Weisbrod, B. A. (2000). Determinants of donations in private nonprofit markets. Journal of Public Economics, 75, 255-272.

Olak, P. A. (2000). Bases para a eficácia na aplicação do contrato de gestão nas organizações sociais brasileiras. Universidade de São Paulo.

Olak, P. A., \& Nascimento, D. T. (2010). o. Contabilidade para entidades sem fins lucrativos (terceiro setor) (3. ed). São Paulo: Atlas.

Oliveira, I. M. da S. (2009). Uma investigação sobre a prestação de contas das entidades do terceiro setor brasileiro. Universidade Federal de Pernambuco.

Olson, D. E. (2000). Agency Theory in the Not-for-Profit Sector: Its Role at Independent Colleges. Nonprofit and Voluntary Sector Quarterly, 29(2), 280-296. http://doi.org/10.1177/0899764000292004

Oster, S. M. (1998). Executive Compensation in the Nonprofit Sector. Nonprofit Management \& Leadership, 8(3), 207-221.

Parsons, J. T. (2003). Focal adhesion kinase: the first ten years. Journal of Cell Science, 116(8), 1409-1416. http://doi.org/10.1242/jcs.00373

Parsons, L. M. (2001). The impact of financial information and voluntary disclosures on contributions to not-for-profit organizations: a field-based experiment. George Mason University. Retrieved from http://papers.ssrn.com/sol3/papers.cfm?abstract_id=406760

Parsons, L. M. (2007). The impact of financial information and voluntary disclosures on contributions to not-for-profit organizations. Behavioral Research in Accounting, 19, 179196.

Pereira, C. (2006). Sustentabilidade e captação de recursos na educação superior no Brasil. (1st ed.). São Paulo: Saraiva. 
Pereira, C. F. de J. (2001). Captação de recursos (fund raising): conhecendo melhor porque as pessoas contribuem. São Paulo: Editora Mackenzie.

Petrovits, C., Shakespeare, C., \& Shih, A. (2011). The Causes and Consequences of Internal Control Problems in Nonprofit Organizations Christine. The Accounting Review, 86(1), $325-357$.

Pharoah, C., \& Tanner, S. (1997). Trends in charitable giving. The Journal of Applied Public Economics, 18(4), 427-443.

Portulhak, H., Delay, A. J., \& Pacheco, V. (2015). Prestação de contas por entidades do Terceiro Setor e seus impactos na obtenção de recursos: um olhar sobre o comportamento dos doadores individuais. Pensar Contábil, 17(64), 39-47.

Portulhak, H., Vaz, P. V. C., Delay, A. J., \& Pacheco, V. (2017). a Qualidade Da Prestação De Contas Das Entidades Do Terceiro Setor: Uma Análise a Partir De Sua Relação Com O Comportamento Dos Doadores Individuais. Enfoque: Reflexão Contábil, 36(1), 45. http://doi.org/10.4025/enfoque.v36i1.31273

Preyra, C., \& Pink, G. (2001). Balancing incentives in the compensation contracts of nonprofit hospital CEOs. Journal of Health Economics, 20(4), 509-25. Retrieved from http://www.ncbi.nlm.nih.gov/pubmed/11463186

Reiser, D. B. (2005). There Ought To Be A Law: The Disclosure Focus Of Recent Legislative Proposals For Nonprofit Reform. Chicago-Kent Law Review, 80, 559-612.

Rengel, S., Cunha, P. R. da, Klann, R. C., \& Scarpin, J. E. (2012). Importância do Balanço Social para as Entidades do Terceiro Setor sob a Ótica dos Gestores das APAES da Região do Alto Vale do Itajaí / SC. Pensar Contábil, 14(53), 5-15.

Roberts, P. W., \& Dowling, G. R. (2002). Corporate reputation and sustained superior financial performance. Strategic Management Journal, 23(12), 1077-1093. http://doi.org/10.1002/smj.274

Rodrigues, L. F. de A. (2012). A perceção da marca no Terceiro Setor e a sua influência na intenção de doar. Universidade da Beira Interior.

Roomkin, M. (1999). Managerial compensation and incentives in for-profit and nonprofit hospitals. Journal of Law, Economics, and Organization, 15(3), 750-781. http://doi.org/10.1093/jleo/15.3.750

Sanders, W. G. (2001). Incentive alignment, CEO pay level, and firm performance : a case of " heads i win , tails you lose "? Human Resource Management, 40(2), 159-170.

Sargeant, A., Ford, J. B., \& West, D. C. (2006). Perceptual determinants of nonprofit giving behavior. Journal of Business Research, 59(2), 155-165. http://doi.org/10.1016/j.jbusres.2005.04.006

Sargeant, A., \& Lee, S. (2004). Trust and relationship commitment in the United Kingdom voluntary sector: Determinants of donor behavior. Psychology and Marketing, 21(8), 613635. http://doi.org/10.1002/mar.20021

Saunah, Z., Ruhaya, A., Yap, B. W., \& Raja Adzrin, R. A. (2012). Information Disclosure by Charity Organizations. Recent Advances in Business Administration, 39-44.

Saxton, G. D., \& Guo, C. (2011). Accountability online: Understanding the Web-based accountability practices of nonprofit organizations. Nonprofit and Voluntary Sector Quarterly, 40(2), 270-295. http://doi.org/10.1177/0899764009341086 
Saxton, G. D., Jenn-Shyong Kuo, \& Ho, Y.-C. (2012). The Determinants of Voluntary Financial Disclosure by Nonprofit Organizations. Nonprofit and Voluntary Sector Quarterly, 41, 1051-1071.

Scheunemann, A. V., \& Rheinheimer, I. (2013). Administração do terceiro setor (1 ed). Curitiba: InterSaberes.

Schloderer, M. P., Sarstedt, M., \& Ringle, C. M. (2014). The relevance of reputation in the nonprofit sector: the moderating effect of socio-demographic characteristics, 126(April), 110-126. http://doi.org/10.1002/nvsm

Shadish, W. R., Cook, T. D., \& Campbell, D. T. (2002). Experimental and QuasiExperimental for Generalized Designs Causal Inference. Handbook of Industrial and Organizational Psychology, 223, 623. http://doi.org/10.1198/jasa.2005.s22

Silva, C. E. G. (2010). Gestão, legislação e fontes de recursos no terceiro setor brasileiro : uma perspectiva histórica. Revista de Administração Pública, 44(6), 1301-1325.

Silva, J. C. da, Dockhorn, M., \& Scarpin, J. E. (2012). Como é a percepção do financiador privado sobre a prestação de contas de uma organização do terceiro setor? O caso sobre a Scar - sociedade de cultura artística de Jaraguá do Sul. Revista Interdisciplinar Científica Aplicada, 6(4), 54-79.

Silvergleid, J. E. (2003). Effects of watchdog organizations on the social capital market. New Directions for Philanthropic Fundraising, 2003(41), 7-26. http://doi.org/10.1002/pf.38

Silverman, D. (2009). Interpretações de dados qualitativos; métodos para análise de entrevistas, textos e interações. Porto Alegre: Artmed.

Sloan, M. F. (2008). The Effects of Nonprofit Accountability Ratings on Donor Behavior. Nonprofit and Voluntary Sector Quarterly, 38(2), 220-236. http://doi.org/10.1177/0899764008316470

Speckbacher, G. (2012). The Use of Incentives in Nonprofit Organizations. Nonprofit and Voluntary Sector Quarterly, 42(5), 1006-1025. http://doi.org/10.1177/0899764012447896

Steinwald, B., \& Neuhauser, D. (1970). The Role of the Proprietary Hospital. Law and Contemporary Problems, 35(4), 817-838.

STF. (2015). STF. from http://www.stf.jus.br/portal/remuneracao/listarRemuneracao.asp?periodo $=052015 \&$ ano $=20$ $15 \&$ mes $=05 \&$ folha $=1$

Tinkelman, D. (1998). Differences in Sensitivity of Financial Statement Users to Joint Cost Allocations: The Case of Nonprofit Organizations. Journal of Accounting, Auditing \& Finance, 13(4), 377-394.

Tinkelman, D., \& Donabedian, B. (2007). Street Lamps, Alleys, Ratio Analysis, and Nonprofit Organizations. Nonprofit Management \& Leadership, 18(1), 5-18. http://doi.org/10.1002/nml

Trussel, J. M., \& Parsons, L. M. (2007). Financial Reporting Factors Affecting Donations to Charitable Organizations. Advances in Accounting, 23(07), 263-285. http://doi.org/10.1016/S0882-6110(07)23010-X

Turner, J. C., \& Oakes, P. J. (1986). The significance of the social identity concept for social psychology with reference to individualism, interactionism and social influence. British Journal of Social Psychology, 25, 237-252. http://doi.org/10.1111/j.2044- 
8309.1986.tb00732.x

Verrecchia, R. E. (1983). Discretionary disclosure. Journal of Accounting and Economics, (5), 179-194.

Verrecchia, R. E. (2001). Essays on disclosure. Journal of Accounting and Economics, 32(1), 97-180.

Vieira, R. F. (2004). Comunicação Organizacional (1st ed.). Rio de Janeiro: Mauad.

Wagenhofer, A. (1990). Voluntary disclosure with a strategic opponent. Journal of Accounting and Economics, 12(4), 341-363.

Watts, R. L., \& Zimmerman, J. L. (1986). Positive Accounting Theory. Prentice-Hall Inc.

Weerawardena, J., \& Mort, G. S. (2008). Guest editorial: nonprofit competitive strategy. International Journal of Nonprofit and Voluntary Sector Marketing, 13(2), 103-106. http://doi.org/10.1002/nvsm.310

Weisbrod, A., \& Dominguez, D. (1986). Demand for collective goods in private nonprofit markets: can fundraising expenditures help overcome free-rider behavior? Journal of Public Economics, 30, 83-95.

Williamson, O. E. (1979). Transaction-Cost Economics: The Governance of Contractual Relations. The Journal of Law \& Economics, 22(2), 233-261. http://doi.org/dx.doi.org/10.1086/466942

Zittei, M. V. M., Politelo, L., \& Scarpin, J. E. (2016). Nível de Evidenciação Contábil de Organizações do Terceiro Setor. Administração Pública E Gestão Social, 8(2), 85-94. 


\section{APÊNDICES}

\section{APÊNDICE 1}

\section{Instruções ao participante}

Prezado participante,

Antes de descrever o estudo, é importante estabelecer duas regras básicas:

1. Inexistência de artifício: Não há no estudo solicitações que busquem enganá-lo ou que tenham como objetivo algo que não é compatível ao que é descrito nas instruções.

\section{Sem conversas ou comentários}

Por favor, abstenha-se de comentários ou outras comunicações sobre qualquer informação referente à sua participação ou ao estudo com os colegas. Se você tiver alguma dúvida, basta levantar a mão e vamos ajudá-lo.

\section{RECOMPENSA}

Pelo seu trabalho em responder ao estudo, você terá um crédito R $\$ 10,00$ em dinheiro.

Do valor total desse crédito de $\mathrm{R} \$ 10$ reais, você poderá optar por:

1. Recebê-lo integralmente em dinheiro para seu uso pessoal ao final de sua participação; ou

2. Doar integralmente para a Organização sem fins lucrativos descrita no estudo; ou

3. Doar parcialmente para a Organização sem fins lucrativos descrita no estudo, recebendo para seu uso pessoal, ao final de sua participação, o valor em dinheiro correspondente à diferença entre o crédito de $\mathrm{R} \$ 10$ reais e o valor doado para a entidade.

\section{Observações importantes:}

- o valor total doado para a Organização sem fins lucrativos poderá ser comprovado mediante recibo de depósito em conta da favorecida.

ATENÇÃO: a recompensa não será concedida em caso de desistência durante a participação neste estudo ou em caso de invalidação por falta de preenchimento de alguma resposta nas sessões ou de invalidação por conversas ou comentários com os outros participantes.

\section{TAREFA}

Você receberá 2 (dois) envelopes:

\section{Primeiro envelope:}

O primeiro envelope contém 2 (duas) páginas. A primeira com informações sobre uma Organização sem Fins Lucrativos e a segunda com a solicitação referente à sua decisão de doação.

Observação importante: Neste envelope você também receberá um código. Guarde-o com você para que possamos efetuar o pagamento da recompensa, conforme sua decisão, em envelope codificado.

Depois de recolhido o primeiro envelope de todos os participantes, você receberá o segundo envelope.

\section{Segundo envelope:}


O $2^{\circ}$ envelope conterá questões breves sobre as informações contidas no $1^{\circ}$ envelope. Portanto, atenção às informações prestadas no primeiro envelope, para que você possa responder o segundo.

Observação importante: enfatizamos que não existem respostas certas ou erradas.

Antes de iniciarmos, indique o percentual aproximado, do total da sua remuneração anual, que você destinou como doação para instituições ou organizações sem fins lucrativos, somente na última declaração de Imposto de renda (IR): $\%$. 


\section{APÊNDICE 2}

Solicitação de doação - caso 1 - Página 1

\section{ENVELOPE 1 - Pág 1 - TEMPO DE RESPOSTA: 04 MINUTOS}

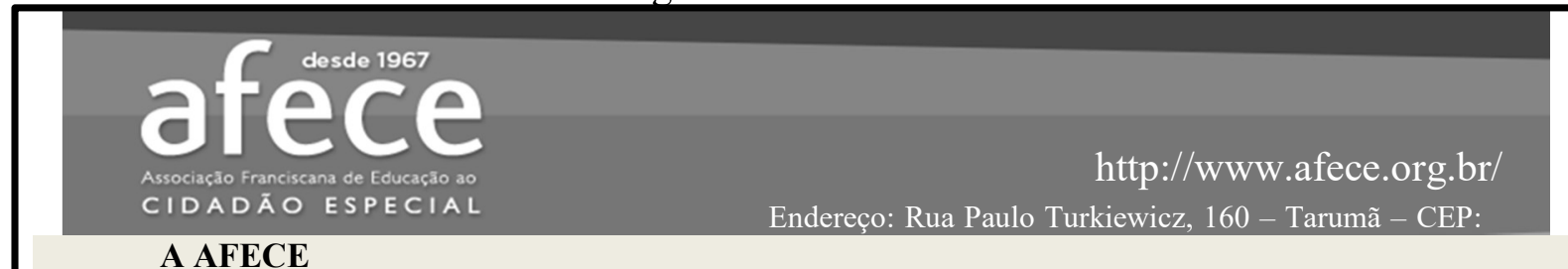

\section{A AFECE}

A AFECE, fundada em 27 de setembro de 1967, vem há 49 anos oferecendo atendimento para Curitiba e região metropolitana nas áreas de Educação, Saúde e Assistência Social.

São atendidas mais de 225 pessoas com deficiência Intelectual de alta especificidade associada ou não a outras patologias, em situação de fragilidade decorrente da pobreza, ausência de renda, acesso precário ou nulo aos serviços públicos ou fragilização de vínculos afetivos.

É a única entidade no sul do Brasil especializada no atendimento de cidadãos especiais com o diagnóstico de deficiência intelectual de alta especificidade, associada ou não a outras patologias.

A entidade realiza um trabalho que estimula o educando a conquistar a maior independência possível na realização das suas atividades diárias, e trabalha para inserir o deficiente no contexto familiar e em toda a sociedade.

\section{Principais Projetos Desenvolvidos}

Projeto de maior sucesso: O Metro Quadrado, que se iniciou em 2005 e ainda está em execução. Com esse projeto foi possível construir mais de $8.000 \mathrm{~m}^{2}$ e a meta é chegar aos 12.000 .

Alguns outros projetos que contribuíram para o desenvolvimento dos programas e serviços:

- $\quad$ Educação Para o Lar;

- $\quad$ Saúde e Educação Para Todos;

- $\quad$ Cidadão com Autonomia;

- $\quad$ Cidadão Saudável Especial e Feliz.

\section{Direção Geral}

Maíra Tavares de Oliveira. 
Solicitação de doação - caso 1 - Página 2

ENVELOPE 1 - Pág 2

\section{afece \\ CIDADÃO ESPECIAL}

Para que a AFECE possa continuar favorecendo avanços nas potencialidades dos seus beneficiários e contribuir para a inclusão em todas as esferas da vida social e proteger a saúde deles, precisamos de sua ajuda!

Participe fazendo uma doação para a AFECE.

Para doar é só preencher o quadro abaixo com o valor que deseja contribuir:

Eu, Código XXXXXXXXXXX , decido que, do valor total de $\mathrm{R} \$ 10,00$, recebido por mim como recompensa na participação desse estudo, estarei doando para a AFECE o montante de R\$

OBS: A doação deverá variar de R $\$ 0$ a R $\$ 10$ reais.

1. Independentemente do valor indicado para doação, qual a probabilidade de você realizar doações futuras para essa organização?

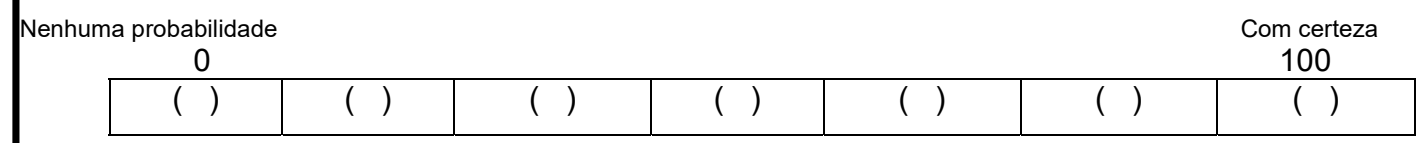

Caso termine de responder antes do tempo, por favor, coloque as folhas respondidas dentro do envelope e aguarde, em silêncio, até que o mesmo seja recolhido. Não é necessário comunicar que você já terminou. 
Solicitação de doação - caso 2 - Página 1

ENVELOPE 1 - Pág 1 - TEMPO DE RESPOSTA: 04 MINUTOS

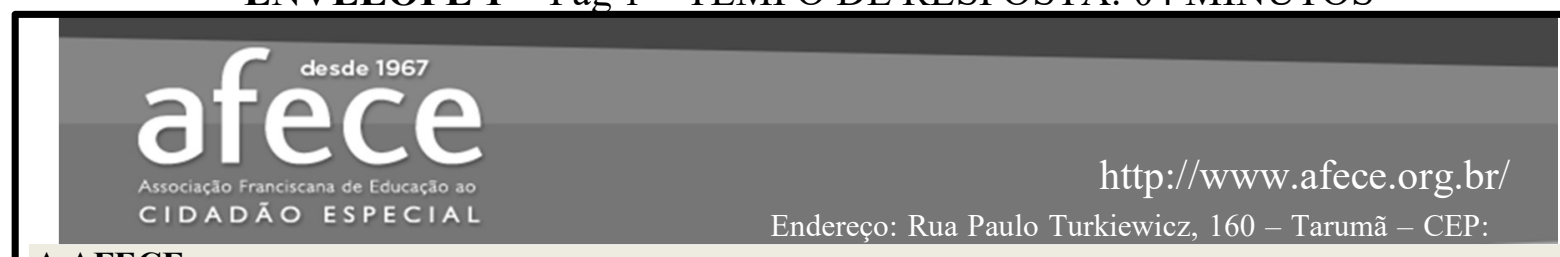

A AFECE

A AFECE, fundada em 27 de setembro de 1967, vem há 49 anos oferecendo atendimento para Curitiba e região metropolitana nas áreas de Educação, Saúde e Assistência Social.

São atendidas mais de 225 pessoas com deficiência Intelectual de alta especificidade associada ou não a outras patologias, em situação de fragilidade decorrente da pobreza, ausência de renda, acesso precário ou nulo aos serviços públicos ou fragilização de vínculos afetivos.

É a única entidade no sul do Brasil especializada no atendimento de cidadãos especiais com o diagnóstico de deficiência intelectual de alta especificidade, associada ou não a outras patologias.

A entidade realiza um trabalho que estimula o educando a conquistar a maior independência possível na realização das suas atividades diárias, e trabalha para inserir o deficiente no contexto familiar e em toda a sociedade.

\section{Principais Projetos Desenvolvidos}

Projeto de maior sucesso: O Metro Quadrado, que se iniciou em 2005 e ainda está em execução. Com esse projeto foi possível construir mais de $8.000 \mathrm{~m}^{2}$ e a meta é chegar aos 12.000 .

Alguns outros projetos que contribuíram para o desenvolvimento dos programas e serviços:

- $\quad$ Educação Para o Lar;

- $\quad$ Saúde e Educação Para Todos;

- $\quad$ Cidadão com Autonomia;

- $\quad$ Cidadão Saudável Especial e Feliz.

\section{Direção Geral}

Maíra Tavares de Oliveira, com remuneração anual de $\mathrm{R} \$ 24.000,00$ (vinte e quatro mil reais) por ano (equivalente a $\mathrm{R} \$ 2.000,00$ [dois mil reais] por mês).

\section{Empresa solidária apoiadora da AFECE:}

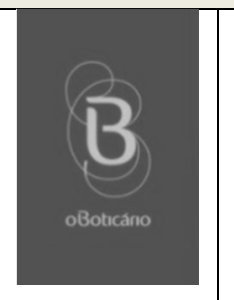

O Boticário atua no segmento de higiene e beleza, em um negócio que engloba

laboratório, pesquisa, fábrica, logística, marketing, varejo. É uma rede

de franquias de cosméticos e perfumes brasileira, com sede no Paraná. Seus principais produtos são fragrâncias, cremes e produtos para maquiagem. 
ENVELOPE 1 - Pág 2

\section{afece \\ CIDADÃO ESPECIAL}

Para que a AFECE possa continuar favorecendo avanços nas potencialidades dos seus beneficiários e contribuir para a inclusão em todas as esferas da vida social e proteger a saúde deles, precisamos de sua ajuda!

Participe fazendo uma doação para a AFECE.

Para doar é só preencher o quadro abaixo com o valor que deseja contribuir:

\section{Eu, Código XXXXXXXXXXX} decido que, do valor total

de $\mathrm{R} \$ 10,00$, recebido por mim como recompensa na participação desse estudo, estarei doando para a AFECE o montante de R\$

OBS: A doação deverá variar de R\$ 0 a R $\$ 10$ reais.

1. Independentemente do valor indicado para doação, qual a probabilidade de você realizar doações futuras para essa organização?

\begin{tabular}{l}
$\begin{array}{c}\text { Nenhuma probabilidade } \\
0\end{array}$ \\
\begin{tabular}{|c|c|c|c|c|c|c|}
\hline Com certeza \\
100
\end{tabular} \\
\hline
\end{tabular}

Caso termine de responder antes do tempo, por favor, coloque as folhas respondidas dentro do envelope e aguarde, em silêncio, até que o mesmo seja recolhido. Não é necessário comunicar que você já terminou. 
Solicitação de doação - caso 3 - Página 1

ENVELOPE 1 - Pág 1 - TEMPO DE RESPOSTA: 04 MINUTOS

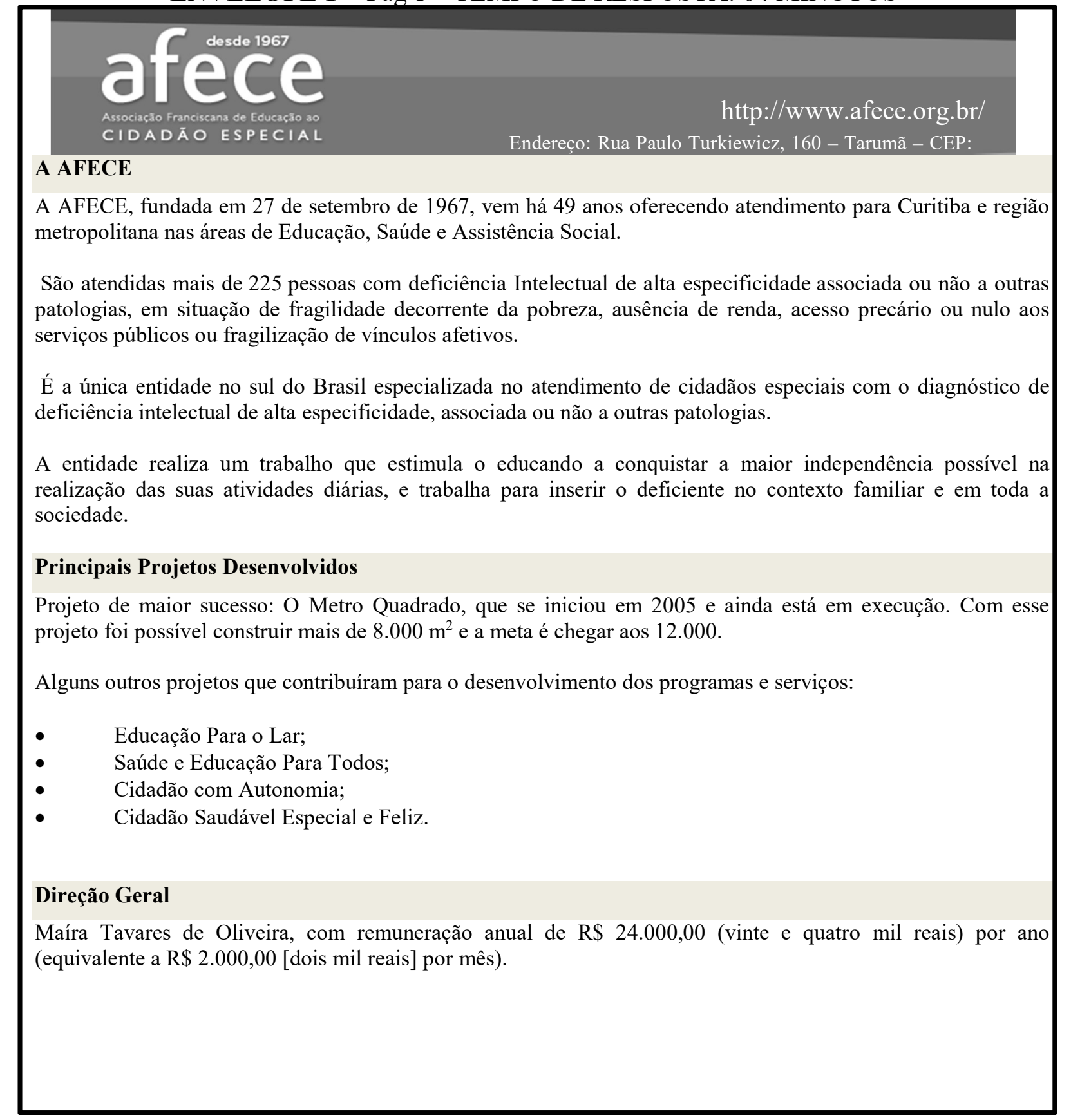


ENVELOPE 1 - Pág 2

\section{afece \\ Associação Franciscana de Educaçăo ao \\ CIDADÃO ESPECIAL}

Para que a AFECE possa continuar favorecendo avanços nas potencialidades dos seus beneficiários e contribuir para a inclusão em todas as esferas da vida social e proteger a saúde deles, precisamos de sua ajuda!

Participe fazendo uma doação para a AFECE.

Para doar é só preencher o quadro abaixo com o valor que deseja contribuir:

Eu, Código XXXXXXXXXXX decido que, do valor total

de $\mathrm{R} \$ 10,00$, recebido por mim como recompensa na participação desse estudo, estarei doando para a AFECE o montante de R\$

OBS: A doação deverá variar de R\$ 0 a R\$ 10 reais.

1. Independentemente do valor indicado para doação, qual a probabilidade de você realizar doações futuras para essa organização?

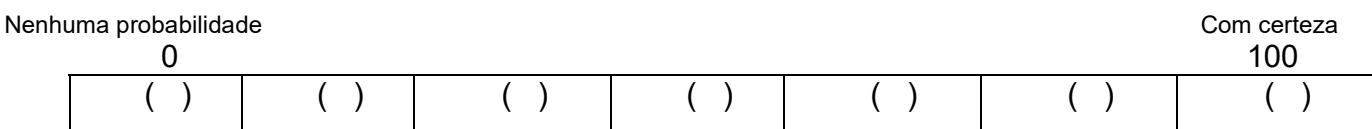

Caso termine de responder antes do tempo, por favor, coloque as folhas respondidas dentro do envelope e aguarde, em silêncio, até que o mesmo seja recolhido. Não é necessário comunicar que você já terminou. 
Solicitação de doação - caso 4 - Página 1

ENVELOPE 1 - Pág 1 - TEMPO DE RESPOSTA: 04 MINUTOS

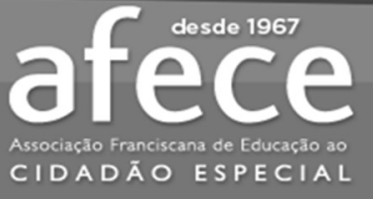

http://www.afece.org.br/

A AFECE

A AFECE, fundada em 27 de setembro de 1967, vem há 49 anos oferecendo atendimento para Curitiba e região metropolitana nas áreas de Educação, Saúde e Assistência Social.

São atendidas mais de 225 pessoas com deficiência Intelectual de alta especificidade associada ou não a outras patologias, em situação de fragilidade decorrente da pobreza, ausência de renda, acesso precário ou nulo aos serviços públicos ou fragilização de vínculos afetivos.

É a única entidade no sul do Brasil especializada no atendimento de cidadãos especiais com o diagnóstico de deficiência intelectual de alta especificidade, associada ou não a outras patologias.

A entidade realiza um trabalho que estimula o educando a conquistar a maior independência possível na realização das suas atividades diárias, e trabalha para inserir o deficiente no contexto familiar e em toda a sociedade.

\section{Principais Projetos Desenvolvidos}

Projeto de maior sucesso: O Metro Quadrado, que se iniciou em 2005 e ainda está em execução. Com esse projeto foi possível construir mais de $8.000 \mathrm{~m}^{2}$ e a meta é chegar aos 12.000 .

Alguns outros projetos que contribuíram para o desenvolvimento dos programas e serviços:

- $\quad$ Educação Para o Lar;

- $\quad$ Saúde e Educação Para Todos;

- $\quad$ Cidadão com Autonomia;

- $\quad$ Cidadão Saudável Especial e Feliz.

\section{Direção Geral}

Maíra Tavares de Oliveira, com remuneração anual de R\$ 60.000,00 (sessenta mil reais) por ano (equivalente a R\$ 5.000,00 [cinco mil reais] por mês).

\section{Empresa solidária apoiadora da AFECE:}

O Boticário atua no segmento de higiene e beleza, em um negócio que engloba
laboratório, pesquisa, fábrica, logística, marketing, varejo. É uma rede
de franquias de cosméticos e perfumes brasileira, com sede no Paraná. Seus principais
produtos são fragrâncias, cremes e produtos para maquiagem.


ENVELOPE 1 - Pág 2

\section{afece \\ CIDADÃO ESPECIAL}

Para que a AFECE possa continuar favorecendo avanços nas potencialidades dos seus beneficiários e contribuir para a inclusão em todas as esferas da vida social e proteger a saúde deles, precisamos de sua ajuda!

Participe fazendo uma doação para a AFECE.

Para doar é só preencher o quadro abaixo com o valor que deseja contribuir:

\section{Eu, Código XXXXXXXXXXX} , decido que, do valor total de $\mathrm{R} \$ 10,00$, recebido por mim como recompensa na participação desse estudo, estarei doando para a AFECE o montante de R\$

OBS: A doação deverá variar de R\$ 0 a R\$ 10 reais.

1. Independentemente do valor indicado para doação, qual a probabilidade de você realizar doações futuras para essa organização?

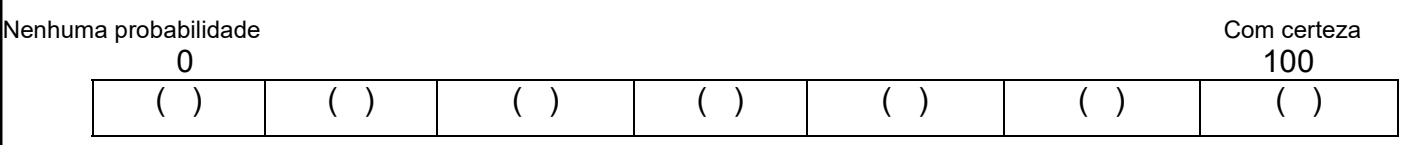

Caso termine de responder antes do tempo, por favor, coloque as folhas respondidas dentro do envelope e aguarde, em silêncio, até que o mesmo seja recolhido. Não é necessário comunicar que você já terminou. 
Solicitação de doação - caso 5 - Página 1

ENVELOPE 1 - Pág 1 - TEMPO DE RESPOSTA: 04 MINUTOS

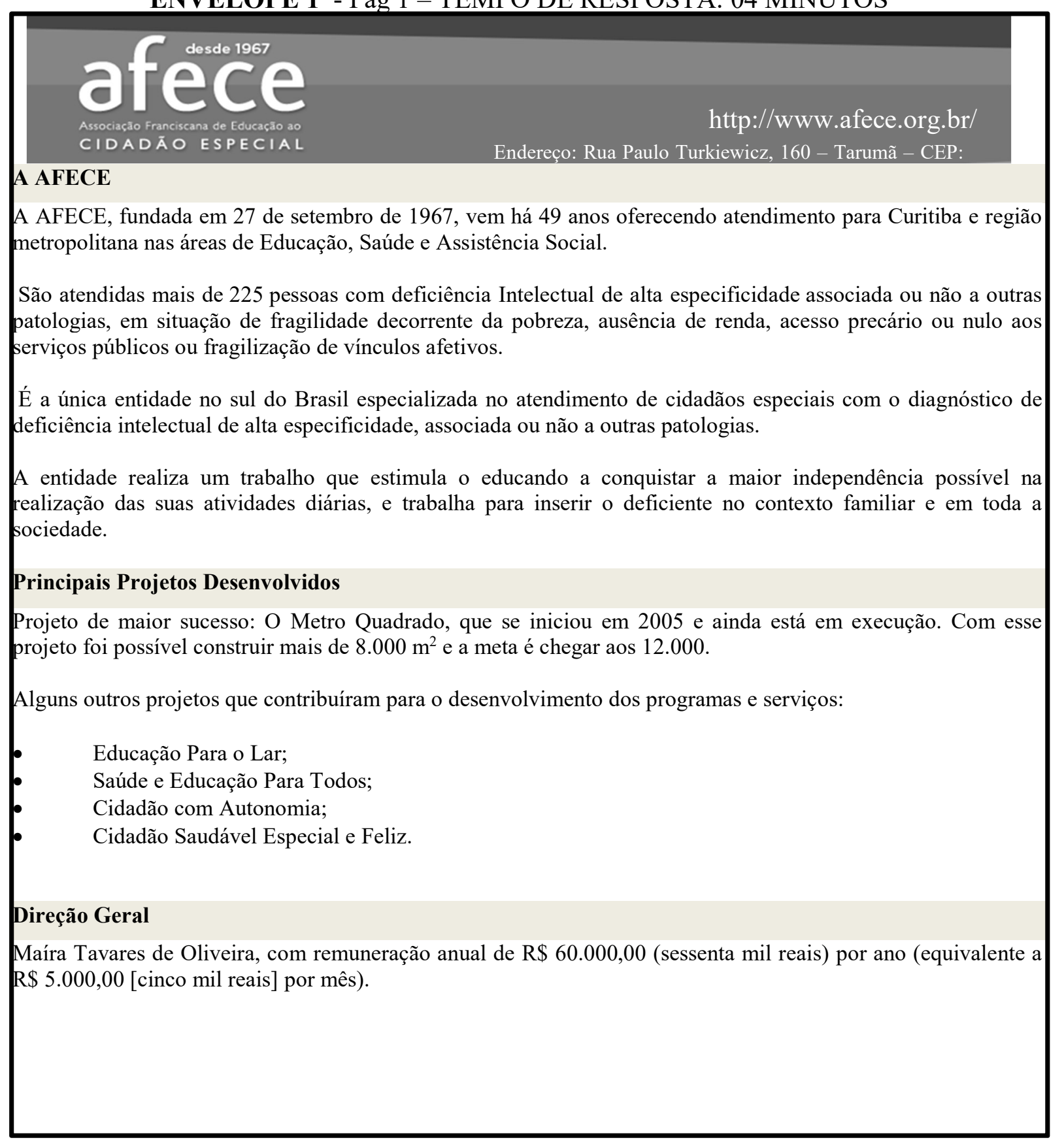


ENVELOPE 1 - Pág 2

\section{afece \\ Associação Franciscana de Educação ao \\ CIDADÃO ESPECIAL}

Para que a AFECE possa continuar favorecendo avanços nas potencialidades dos seus beneficiários e contribuir para a inclusão em todas as esferas da vida social e proteger a saúde deles, precisamos de sua ajuda!

Participe fazendo uma doação para a AFECE.

Para doar é só preencher o quadro abaixo com o valor que deseja contribuir:

\section{Eu,Código XXXXXXXXXXX} , decido que, do valor total de $\mathrm{R} \$ 10,00$, recebido por mim como recompensa na participação desse estudo, estarei doando para a AFECE o montante de R\$

OBS: A doação deverá variar de $\mathrm{R} \$ 0$ a $\mathrm{R} \$ 10$ reais.

1. Independentemente do valor indicado para doação, qual a probabilidade de você realizar doações futuras para essa organização?

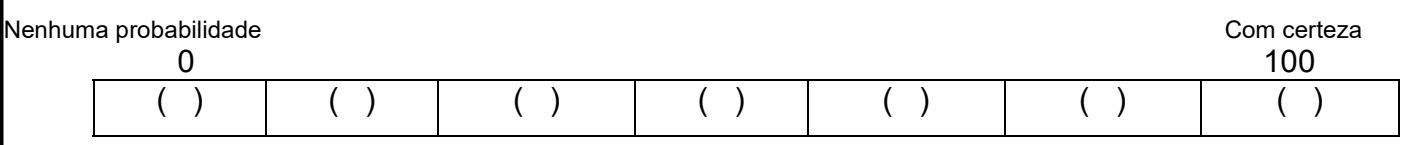

Caso termine de responder antes do tempo, por favor, coloque as folhas respondidas dentro do envelope e aguarde, em silêncio, até que o mesmo seja recolhido. Não é necessário comunicar que você já terminou. 
Solicitação de doação - caso 6 - Página 1

ENVELOPE 1 - Pág 1 - TEMPO DE RESPOSTA: 04 MINUTOS

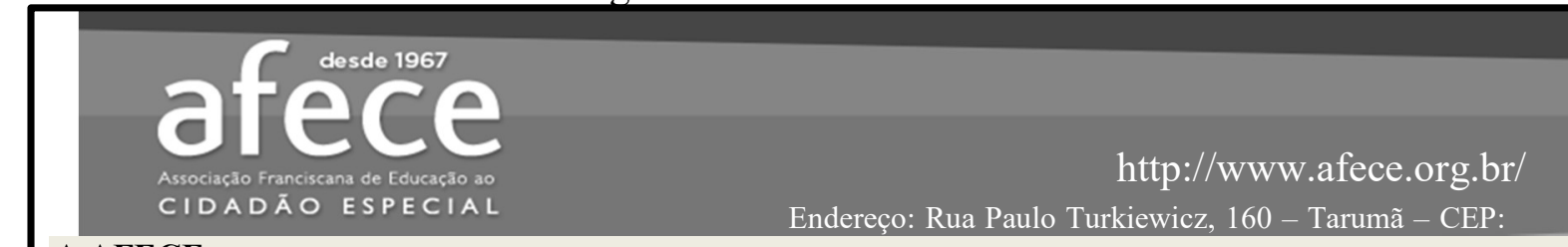

A AFECE

A AFECE, fundada em 27 de setembro de 1967, vem há 49 anos oferecendo atendimento para Curitiba e região metropolitana nas áreas de Educação, Saúde e Assistência Social.

São atendidas mais de 225 pessoas com deficiência Intelectual de alta especificidade associada ou não a outras patologias, em situação de fragilidade decorrente da pobreza, ausência de renda, acesso precário ou nulo aos serviços públicos ou fragilização de vínculos afetivos.

É a única entidade no sul do Brasil especializada no atendimento de cidadãos especiais com o diagnóstico de deficiência intelectual de alta especificidade, associada ou não a outras patologias.

A entidade realiza um trabalho que estimula o educando a conquistar a maior independência possível na realização das suas atividades diárias, e trabalha para inserir o deficiente no contexto familiar e em toda a sociedade.

\section{Principais Projetos Desenvolvidos}

Projeto de maior sucesso: O Metro Quadrado, que se iniciou em 2005 e ainda está em execução. Com esse projeto foi possível construir mais de $8.000 \mathrm{~m}^{2}$ e a meta é chegar aos 12.000 .

Alguns outros projetos que contribuíram para o desenvolvimento dos programas e serviços:

- $\quad$ Educação Para o Lar;

- $\quad$ Saúde e Educação Para Todos;

- $\quad$ Cidadão com Autonomia;

- $\quad$ Cidadão Saudável Especial e Feliz.

\section{Direção Geral}

Maíra Tavares de Oliveira, com remuneração anual de R\$ 96.000,00 (noventa e seis mil reais) por ano (equivalente a $\mathrm{R} \$ 8.000,00$ [oito mil reais] por mês).

Empresa solidária apoiadora da AFECE:

\begin{tabular}{|c|c|}
\hline O Boticário atua no segmento de higiene e beleza, em um negócio que engloba \\
laboratório, pesquisa, fábrica, logística, marketing, varejo. É uma rede \\
de franquias de cosméticos e perfumes brasileira, com sede no Paraná. Seus principais \\
produtos são fragrâncias, cremes e produtos para maquiagem.
\end{tabular}


ENVELOPE 1 - Pág 2

\section{Associaçåo Franciscana de Educaçăo ao \\ CIDADÃO ESPECIAL}

Para que a AFECE possa continuar favorecendo avanços nas potencialidades dos seus beneficiários e contribuir para a inclusão em todas as esferas da vida social e proteger a saúde deles, precisamos de sua ajuda!

Participe fazendo uma doação para a AFECE.

Para doar é só preencher o quadro abaixo com o valor que deseja contribuir:

\section{Eu, Código XXXXXXXXXXX} , decido que, do valor total de $\mathrm{R} \$ 10,00$, recebido por mim como recompensa na participação desse estudo, estarei doando para a AFECE o montante de R\$

OBS: A doação deverá variar de R\$ 0 a R\$ 10 reais.

1. Independentemente do valor indicado para doação, qual a probabilidade de você realizar doações futuras para essa organização?

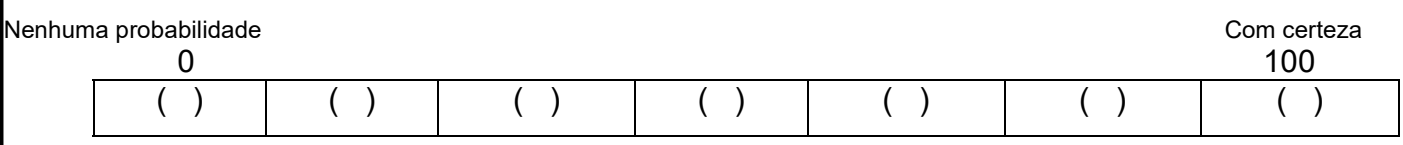

Caso termine de responder antes do tempo, por favor, coloque as folhas respondidas dentro do envelope e aguarde, em silêncio, até que o mesmo seja recolhido. Não é necessário comunicar que você já terminou. 
Solicitação de doação - caso 7 - Página 1

ENVELOPE 1 - Pág 1 - TEMPO DE RESPOSTA: 04 MINUTOS

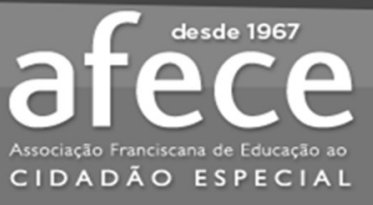

http://www.afece.org.br/

CIDADĀO ESPECIAL

Endereço: Rua Paulo Turkiewicz, 160 - Tarumã - CEP:

A AFECE

A AFECE, fundada em 27 de setembro de 1967, vem há 49 anos oferecendo atendimento para Curitiba e região metropolitana nas áreas de Educação, Saúde e Assistência Social.

São atendidas mais de 225 pessoas com deficiência Intelectual de alta especificidade associada ou não a outra patologias, em situação de fragilidade decorrente da pobreza, ausência de renda, acesso precário ou nulo aos serviços públicos ou fragilização de vínculos afetivos.

É a única entidade no sul do Brasil especializada no atendimento de cidadãos especiais com o diagnóstico de deficiência intelectual de alta especificidade, associada ou não a outras patologias.

A entidade realiza um trabalho que estimula o educando a conquistar a maior independência possível na realização das suas atividades diárias, e trabalha para inserir o deficiente no contexto familiar e em toda a sociedade.

\section{Principais Projetos Desenvolvidos}

Projeto de maior sucesso: O Metro Quadrado, que se iniciou em 2005 e ainda está em execução. Com esse projeto foi possível construir mais de $8.000 \mathrm{~m}^{2}$ e a meta é chegar aos 12.000 .

Alguns outros projetos que contribuíram para o desenvolvimento dos programas e serviços:

- $\quad$ Educação Para o Lar;

- $\quad$ Saúde e Educação Para Todos;

- $\quad$ Cidadão com Autonomia;

- $\quad$ Cidadão Saudável Especial e Feliz.

\section{Direção Geral}

Maíra Tavares de Oliveira, com remuneração anual de R\$ 96.000,00 (noventa seis mil reais) por ano (equivalente a $\mathrm{R} \$ 8.000,00$ [oito mil reais] por mês). 
ENVELOPE 1 - Pág 2

\section{afece \\ Associação Franciscana de Educaçăo ao \\ CIDADÃO ESPECIAL}

Para que a AFECE possa continuar favorecendo avanços nas potencialidades dos seus beneficiários e contribuir para a inclusão em todas as esferas da vida social e proteger a saúde deles, precisamos de sua ajuda!

Participe fazendo uma doação para a AFECE.

Para doar é só preencher o quadro abaixo com o valor que deseja contribuir:

$\mathrm{Eu}$, , decido que, do valor total

de $\mathrm{R} \$ 10,00$, recebido por mim como recompensa na participação desse estudo, estarei doando para a AFECE o montante de R\$

OBS: A doação deverá variar de R\$ 0 a R\$ 10 reais.

1. Independentemente do valor indicado para doação, qual a probabilidade de você realizar doações futuras para essa organização?

Nenhuma probabilidade
0
\begin{tabular}{|c|c|c|c|c|c|c|}
$\begin{array}{c}\text { Com certeza } \\
100\end{array}$ \\
\hline$(~)$ & $(\mathrm{l})$ & $(\mathrm{l})$ & $(\mathrm{l})$ & $(\mathrm{l})$ & $(\mathrm{l})$ & $(\mathrm{)}$ \\
\hline
\end{tabular}

Caso termine de responder antes do tempo, por favor, coloque as folhas respondidas dentro do envelope e aguarde, em silêncio, até que o mesmo seja recolhido. Não é necessário comunicar que você já terminou. 


\section{APÊNDICE 3}

Questões a respeito das informações contidas e respondidas nos casos

\section{TODOS OS CASOS (1 a 7)}

1. Em sua opinião, relativamente ao que você espera que seja pago em forma de remuneração a um dirigente de Organização Sem Fins Lucrativos, como você avalia a remuneração do dirigente da AFECE é:

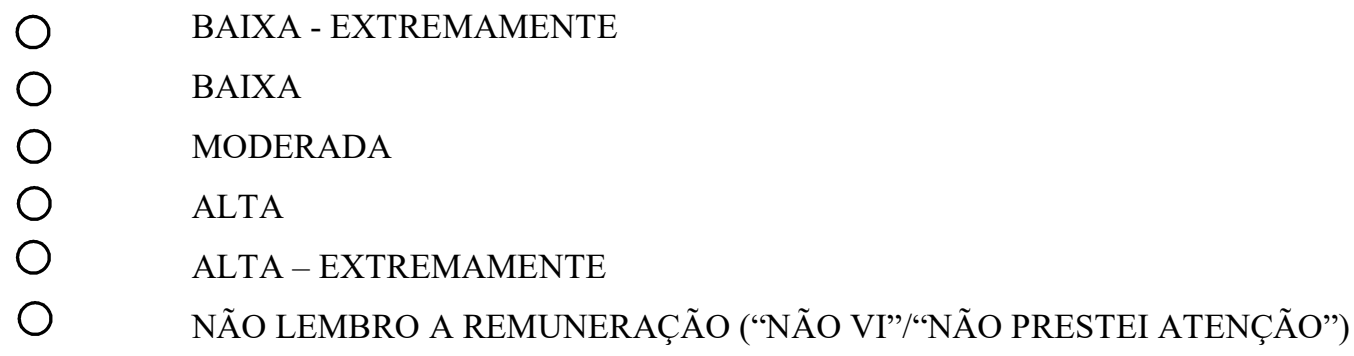

2. Indique os três fatores mais importantes que influenciaram a sua escolha do valor a ser doada para a AFECE.

Primeiro mais importante:

Segundo mais importante:

Terceiro mais importante:

3. Você já conhecia a AFECE antes de participar deste estudo?
O SIM
O NÃO

4. Você ou algum conhecido (família, amigo, etc.) é/foi atendido pela AFECE?
O SIM
○ NÃO

5. Você ou algum conhecido (família, amigo, etc.) faz/fez doação para organização sem fins lucrativos?

$\bigcirc$

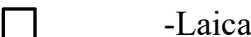

- Outro:

a. Se respondeu SIM à questão 5 (cinco), a doação é/era periódica? 
6. Você ou algum conhecido (família, amigo, etc.) trabalha/trabalhou em organização sem fins lucrativos?
$\mathrm{O}$
SIM
0
NÃO

7. Considerando as informações disponibilizadas pela AFECE, indique o seu grau de concordância com as seguintes afirmativas:

\begin{tabular}{|c|c|c|c|c|c|}
\hline \multirow[b]{2}{*}{ Acredito que a AFECE... } & 1 & 2 & 3 & 4 & 5 \\
\hline & $\begin{array}{l}\text { Discordo } \\
\text { fortemente }\end{array}$ & $\begin{array}{c}\text { Discordo } \\
\text { parcialmente }\end{array}$ & $\begin{array}{l}\text { Nem } \\
\text { discordo, nem } \\
\text { concordo }\end{array}$ & $\begin{array}{c}\text { Concordo } \\
\text { parcialmente }\end{array}$ & $\begin{array}{l}\text { Concordo } \\
\text { fortemente }\end{array}$ \\
\hline \multicolumn{6}{|l|}{ atua para o melhor interesse em prol da causa } \\
\hline \multicolumn{6}{|l|}{...conduz suas operações de maneira ética } \\
\hline \multicolumn{6}{|l|}{$\begin{array}{l}\text {...usa apropriadamente os recursos recebidos em } \\
\text { forma de doação }\end{array}$} \\
\hline \multicolumn{6}{|l|}{...não tira vantagem dos seus doadores } \\
\hline \multicolumn{6}{|l|}{$\begin{array}{l}\text {...usa técnicas apropriadas e respeitosas para } \\
\text { angariar recursos }\end{array}$} \\
\hline ...é uma organização confiável & & & & & \\
\hline
\end{tabular}

8. Qual sua renda familiar mensal? Selecione uma das faixas abaixo:

( $\mathrm{SM}=$ salário mínimo)

Até $2 \mathrm{SM}$ (até $\mathrm{R} \$ 1.760,00)$
Maior que 2 até $4 \mathrm{SM}($ de $\mathrm{R} \$ 1.760,01$ até $\mathrm{R} \$ 3.520,00)$
Maior que 4 até $10 \mathrm{SM}($ de $\mathrm{R} \$ 3.520,01$ até $\mathrm{R} \$ 8.800,00)$
Maior que 10 até $20 \mathrm{SM}($ de $\mathrm{R} \$ 8.800,01$ até $17.600,00)$
Acima de $20 \mathrm{SM}$ (acima de $\mathrm{R} \$ 17.600,00)$


APÊNDICE 4

\begin{tabular}{|c|c|}
\hline & $\begin{array}{l}\text { rezado participante, caso queira receber um resumo com o objetivo da pesquisa e os resultados } \\
\text { principais deste estudo, favor colocar seu e-mail abaixo: }\end{array}$ \\
\hline 1 & \\
\hline 2 & \\
\hline 3 & \\
\hline 4 & \\
\hline 5 & \\
\hline 6 & 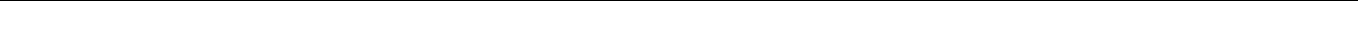 \\
\hline 7 & \\
\hline 8 & \\
\hline 9 & ( \\
\hline 10 & \\
\hline 11 & \\
\hline 12 & \\
\hline 13 & ( \\
\hline 14 & \\
\hline 15 & \\
\hline 16 & \\
\hline 17 & \\
\hline 18 & \\
\hline 19 & \\
\hline 20 & \\
\hline 21 & \\
\hline 22 & \\
\hline 23 & \\
\hline 24 & \\
\hline 25 & \\
\hline 26 & \\
\hline 27 & \\
\hline 28 & \\
\hline 29 & \\
\hline 30 & \\
\hline 31 & \\
\hline 32 & \\
\hline 33 & \\
\hline 34 & \\
\hline 35 & \\
\hline 36 & \\
\hline 37 & \\
\hline 38 & \\
\hline 39 & \\
\hline 40 & \\
\hline 41 & \\
\hline 42 & \\
\hline 43 & \\
\hline 44 & \\
\hline 45 & \\
\hline
\end{tabular}




\section{APÊNDICE 5}

\section{PPGCC \\ Programa de Pós-Graduação em Controladoria e Contabilidade}

\section{TERMO DE CONSENTIMENTO LIVRE E ESCLARECIDO}

Prezado participante,

Convido-o(a) a participar voluntariamente desse estudo sobre a "tomada de decisão e doações para OSFL laicas (não religiosas)". Não existem respostas certas ou erradas e você não será julgado ou avaliado com base em suas respostas.

Garanto o anonimato, sigilo, privacidade e confidencialidade das respostas, sem o risco de que seus dados individuais sejam identificados. Para tanto, será resguardado o nome de cada participante. Suas informações serão analisadas em conjunto com as de outros participantes, não permitindo a sua identificação individual.

Em qualquer etapa da pesquisa você terá o direito de se retirar do estudo. A sua decisão em não participar da pesquisa em nada afetará a sua relação com os pesquisadores integrantes da pesquisa ou com as instituições envolvidas na pesquisa.

Caso você tenha alguma consideração ou dúvida sobre os aspectos éticos da pesquisa, poderá entrar em contato com um dos integrantes da equipe de pesquisa.

\section{A equipe de pesquisa é composta pelos seguintes integrantes:}

1. Sayuri Unoki de Azevedo, aluna de Doutorado do Programa de Pós-Graduação em Controladoria e Contabilidade da Universidade de São Paulo (sayuri.unoki@gmail.com.br).

2. Andson Braga de Aguiar, Professor Doutor do Programa de Pós-Graduação em Controladoria e Contabilidade da Universidade de São Paulo (abraga@usp.br).

Diante desses esclarecimentos, assinale uma das duas alternativas a seguir:

( ) Diante da leitura e dos esclarecimentos adicionais, eu declaro minha ciência com relação aos procedimentos do estudo sobre tomada de decisão e doações para OSFL laicas (não religiosas) e minha disposição de participar voluntariamente.

( ) Não concordo em participar (Neste caso, encerre sua participação neste estudo).

Local:

Data:

Nome:

Assinatura: 


\title{
APÊNDICE 6
}

\section{PPGCC 应 \\ Programa de Pós-Graduação em Controladoria e Contabilidade}

\section{CARTA DE ESCLARECIMENTO DE INFORMAÇÕES}

\author{
Prezado participante,
}

Inicialmente gostaríamos de agradecer por sua participação neste estudo, sendo de grande valia para o desenvolvimento do conhecimento.

Gostaríamos de esclarecer que a AFECE é uma organização sem fins lucrativos com grande valor social e, para que não haja nenhum prejuízo à imagem da organização, salientamos que a informação relatada no estudo que você participou, referente ao valor recebido de remuneração pela dirigente, Sra. Maíra de Oliveira, não é verdadeiro, sendo, portanto, um valor fictício estabelecido pelos pesquisadores responsáveis para que a pesquisa pudesse ser viabilizada em consonância à literatura de base que subsidiou a construção do presente estudo.

A AFECE não efetua qualquer tipo de pagamento à dirigente da organização, Sra. Maíra de Oliveira, sendo esta remunerada a partir de convênios de cooperação técnica municipal com o município de Almirante Tamandaré e com o Governo do Estado do Paraná.

Adicionalmente, para seu melhor conhecimento sobre a AFECE, organização parceira deste estudo, você poderá acessar o seguinte endereço eletrônico: http://www.afece.org.br/.

Muito Obrigada!

Atenciosamente, 


\section{APÊNDICE 7}

Bom dia!

Meu nome é Sayuri .

Vocês estão sendo convidados a participar de um estudo sério que irá compor uma tese de doutoramento sobre decisão de doação.

Primeiro vou entregar as instruções sobre o estudo. Farei a leitura em voz alta para que vocês possam acompanhar.

Juntamente com as instruções, estarei entregando um termo que será necessário preencher sobre o aceite da participação de vocês. Apenas para formalizar para o estudo.

\section{ENTREGA DAS FOLHAS}

\section{LEITURA DAS INSTRUÇÕES}

Agora vou pedir para que vocês leiam e assinem o termo com o aceite em participar do estudo e já passo recolhendo.

Qualquer dúvida basta levantar a mão que iremos até você.

\section{RECOLHIMENTO DAS FOLHAS}

Neste momento, começa a tarefa. Vamos entregar o primeiro envelope.

Vocês terão 4 minutos para respondê-lo. Ao receber, você já pode abrir e responder.

Responda como se você recebesse uma solicitação de doação em casa mesmo por carta.

Avisaremos quando faltar 1 minuto para terminar o tempo.

Em caso de dúvidas, levante a mão e iremos até você.

ENTREGA DO PRIMEIRO ENVELOPE

AGUARDAR 3 MINUTOS

AVISAR QUE FALTA 1 MINUTO PARA TERMINAR O TEMPO

AGUARDAR 1 MINUTO

AVISAR QUE O TEMPO ACABOU E PEDIR PARA COLOCAREM AS FOLHAS NOVAMENTE NO ENVELOPE 


\section{RECOLHER OS ENVELOPES}

Neste momento entregaremos o segundo envelope.

Vocês terão 6 minutos para respondê-lo. Ao receber, você já pode abrir e responder.

Avisaremos quando faltar 1 minuto para terminar o tempo.

Em caso de dúvidas, levante a mão e iremos até você.

ENTREGA DO SEGUNDO ENVELOPE

AGUARDAR 5 MINUTOS

AVISAR QUE FALTA 1 MINUTO PARA TERMINAR O TEMPO

AGUARDAR 1 MINUTO

AVISAR QUE O TEMPO ACABOU E PEDIR PARA COLOCAREM AS FOLHAS NOVAMENTE NO ENVELOPE

\section{RECOLHER OS ENVELOPES}

Muito obrigada pela participação!

Estamos passando uma lista para que vocês possam colocar o e-mail de contato caso queiram receber um resumo com o objetivo e os principais resultados do estudo. 


\section{APÊNDICE 8}

Recebi pela participação no estudo sobre tomada de decisão e doações para OSFL

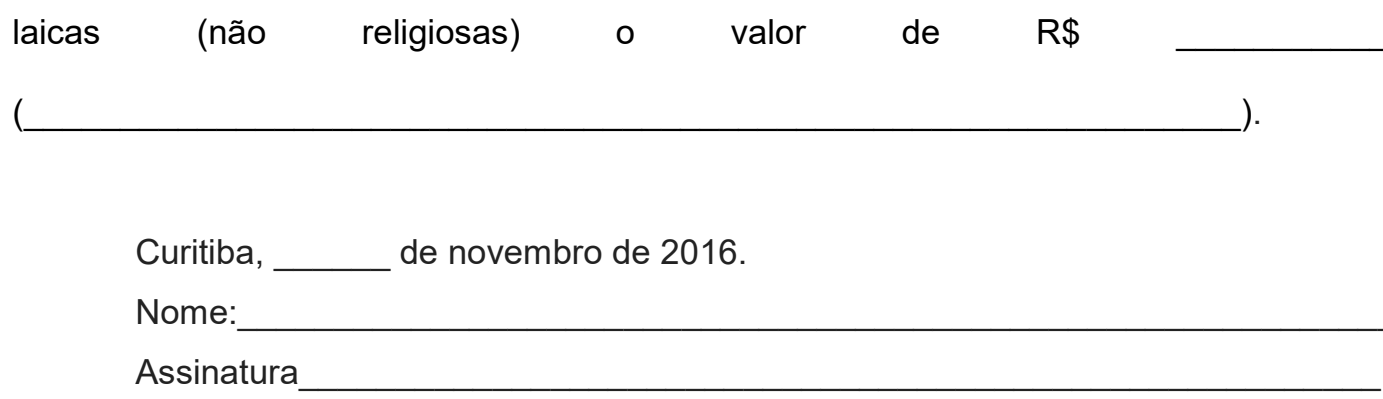




\section{APÊNDICE 9}

\begin{tabular}{|c|c|}
\hline $\begin{array}{l}\text { RESPOSTA } \\
\text { CONSIDERADA }\end{array}$ & RESPOSTAS ORIGINAIS \\
\hline CAUSA & $\begin{array}{l}\text { Causa nobre; causa justa; hierarquia da causa; projeto interessante; importância do } \\
\text { serviço social prestado; a causa-ajuda em relação à independência do cidadão; } \\
\text { finalidade; objeto; objetivo da organização; importância da atividade realizada; } \\
\text { importância da causa; o papel da entidade; o trabalho realizado; atendimento de } \\
\text { inclusão; a causa pela qual a instituição trabalha; por ser centro de caridade; } \\
\text { comprometimento da exigência que a causa tem; educação; dignidade para quem } \\
\text { precisa; benefício aos atendidos; se auxilia ao necessitado; ausência de renda; } \\
\text { decorrência de pobreza; objetivo; propósito; missão; inclusão social; dificuldade de } \\
\text { cuidar de pessoas especiais; educação para o lar; organização trabalha com projetos } \\
\text { importantes; saúde e educação; gosto do trabalho deles; atende pessoas que } \\
\text { realmente precisam; utilidade; a atividade desenvolvida pela AFECE; o } \\
\text { comprometimento da exigência que a causa tem; desenvolvimento; saúde; bem } \\
\text { estar; qualidade de vida; desenvolvimento do trabalho; cidadão com autonomia. }\end{array}$ \\
\hline $\begin{array}{l}\text { DINHEIRO } \\
\text { RECEBIDO DA } \\
\text { PESQUISA }\end{array}$ & $\begin{array}{l}\text { Não precisei desembolsar o valor; desembolso financeiro; não é justo eu receber } 10 \\
\text { reais só por uma pesquisa; não vejo necessidade de receber por participar da } \\
\text { pesquisa; realizei a pesquisa sem intenção de ganhar dinheiro; porque ganhei o } \\
\text { valor a ser doado; dinheiro não é meu; dinheiro não me fará falta; não esperava } \\
\text { receber; não estava esperando; não mereço receber só para responder o estudo; não } \\
\text { precisar do dinheiro; o que foi oferecido; não recebi o dinheiro; não dispunha do } \\
\text { valor - nada de perda; não irá me custar; sensação de não sair do meu orçamento; } \\
\text { não contava com o valor; o valor doado foi para responder o questionário; não é um } \\
\text { dinheiro que eu necessito; não esperava ser remunerado pelo estudo - decidi doar } \\
\text { tudo; não me faz falta; não faria diferença no meu orçamento pessoal; não aceitar } \\
\text { dinheiro só para dar opinião; eu não necessito do valor; não houve desembolso; não } \\
\text { veio de mim. }\end{array}$ \\
\hline $\begin{array}{l}\text { NECESSIDADE } \\
\text { MAIOR DO } \\
\text { OUTRO }\end{array}$ & $\begin{array}{l}\text { Necessidade da instituição; necessidade deles; necessidade de recursos; necessidade } \\
\text { da organização; necessidade de doação; necessidade da entidade; necessidade do } \\
\text { projeto; necessidade das pessoas especiais; necessidade alheia; arcar com despesas; } \\
\text { o fato deles não terem terminado as obras; doar para quem precisa; indiferença para } \\
\text { mim versus diferença para eles (valor); já tenho tudo, eles precisam mais do que eu; } \\
\text { a AFECE precisa mais; impacto maior para os atendidos; necessário mão-de-obra } \\
\text { qualificada que é mais cara; para melhorar a qualidade de vida dos indivíduos; } \\
\text { melhorar a autoestima dos deficientes; depende de doação; custo para manter as } \\
\text { pessoas que não conseguem se deslocar ou realizar atividades sozinhas; indício da } \\
\text { necessidade da AFECE (não conheço); entendo que a AFECE não precisa pagar; } \\
\text { dificuldade de captação de recursos. }\end{array}$ \\
\hline $\begin{array}{l}\text { AJUDAR/ } \\
\text { CARIDADE }\end{array}$ & $\begin{array}{l}\text { Ajudar; ajudar o próximo; fazer o bem; situação pessoal em ajudar; se posso doar, } \\
\text { por que não; colaborar com o próximo; colaborar com a AFECE; costumo ajudar } \\
\text { ONGs; gosto de doar, fazer voluntariado; ajudar a instituição; solidariedade; } \\
\text { caridade; quero ajudar o próximo; poucos contribuem; espírito solidário; gosto de } \\
\text { ajudar; ajudar a associação; ajudar ao projeto; compaixão; ajudar os deficientes. }\end{array}$ \\
\hline $\begin{array}{l}\text { CONTINUIDADE } \\
\text { DO TRABALHO }\end{array}$ & $\begin{array}{l}\text { Colaborar com a continuidade do trabalho; construção de M2; manter o projeto; } \\
\text { ainda estão ampliando/crescendo; projeto em andamento; o fato deles não terem } \\
\text { terminado as obras; restauração; projeto de expansão; estar procurando crescer. }\end{array}$ \\
\hline $\begin{array}{l}\text { BENEFICIÁRIOS/ } \\
\text { PESSOAS } \\
\text { ATENDIDAS }\end{array}$ & $\begin{array}{l}\text { Pessoas atendidas; atendimento ao cidadão especial; especificidade dos } \\
\text { atendimentos; trabalha com pessoas carentes; as pessoas atendidas com deficiência; } \\
\text { pessoas especiais; crianças atendidas; carência dos atendidos; pessoas que ela } \\
\text { ajuda; público atendido; pessoas afetadas; atendimento a portadores especiais; } \\
\text { pessoas com necessidades; situação dos atendidos pela AFECE. }\end{array}$ \\
\hline $\begin{array}{l}\text { INDICAÇÃO/ } \\
\text { INICIATIVA DA }\end{array}$ & $\begin{array}{l}\text { Iniciativa da pesquisadora; indicação da pesquisa; pesquisa e não arrecadação; } \\
\text { forma de abordagem; apelo; a situação; estudo está apoiando a instituição; pesquisa }\end{array}$ \\
\hline
\end{tabular}




\begin{tabular}{|c|c|}
\hline PESQUISA & acadêmica; forma que está pedindo recursos; forma de angariar recursos. \\
\hline VALOR BAIXO & $\begin{array}{l}\text { Valor da doação; valor irrelevante; } 10 \text { reais; a quantidade disponível; não custa } \\
\text { doar; valor da doação; valor não relevante; são só } 10 \text { reais; o valor para doação; } \\
\text { valor doado; valor; relevância do valor doado. }\end{array}$ \\
\hline OSFL & $\begin{array}{l}\text { Entidade sem fins lucrativos; finalidade social; função social da entidade; } \\
\text { instituição; laica; instituição religiosa. }\end{array}$ \\
\hline $\begin{array}{l}\text { NÃO CONHEÇO } \\
\text { A INSTITUIÇÃOO }\end{array}$ & $\begin{array}{l}\text { Desconhecimento da entidade; não conhecer o trabalho/serviço oferecido; } \\
\text { desconhecimento sobre o trabalho; não conhecimento da instituição; precisar } \\
\text { conhecer melhor o local físico. }\end{array}$ \\
\hline $\begin{array}{l}\text { CONHEÇO A } \\
\text { INSTITUIÇ̃̃O/U } \\
\text { SUÁRIOS }\end{array}$ & Conheço a AFECE; conheço os usuários. \\
\hline $\begin{array}{l}\text { COLABORAR } \\
\text { COM A } \\
\text { PESQUISA }\end{array}$ & $\begin{array}{l}\text { Ajudar a pesquisa; ajudar quem está fazendo a pesquisa; contribuir com o estudo; } \\
\text { ajudar os participantes; estímulo à pesquisa. }\end{array}$ \\
\hline $\begin{array}{l}\text { LOCALIZAÇÃO } \\
\text { (MINHA } \\
\text { CIDADE) }\end{array}$ & Ser da minha cidade; localização; por ser de Curitiba. \\
\hline $\begin{array}{l}\text { MINHA } \\
\text { REALIDADE/ } \\
\text { SITUAÇÃO } \\
\text { FINANCEIRA }\end{array}$ & $\begin{array}{l}\text { Dentro da minha realidade não doaria; boa condição financeira; condição } \\
\text { financeira; minha própria renda; situacional. }\end{array}$ \\
\hline $\begin{array}{l}\text { ÉTICA DA } \\
\text { ORGANIZAÇÃO }\end{array}$ & Ética; AFECE parece trabalhar com ética. \\
\hline $\begin{array}{l}\text { DOAÇÃO } \\
\text { PRÁTICA }\end{array}$ & Facilidade/simplificação do processo; praticidade. \\
\hline $\begin{array}{l}\text { INSTITUIÇÃO } \\
\text { (PARECE) } \\
\text { SÉRIA }\end{array}$ & $\begin{array}{l}\text { Instituição séria; AFECE parece séria; seriedade; aparente seriedade da AFECE; } \\
\text { confiabilidade; trabalho sério; é uma instituição séria; confiabilidade da } \\
\text { organização; confiabilidade. }\end{array}$ \\
\hline $\begin{array}{l}\text { RESPONSABILIDADE } \\
\text { SOCIAL }\end{array}$ & $\begin{array}{l}\text { A questão social; contribuir para a sociedade; acho o correto; importância; } \\
\text { importância de doar; mundo melhor, menos egoísta; meu papel social; bem comum; } \\
\text { consciência. }\end{array}$ \\
\hline $\begin{array}{l}\text { INFORMAÇÕES } \\
\text { SOBRE A } \\
\text { INSTITUIĈÃO } \\
\text { (TRANSPARÊNCIA) }\end{array}$ & Histórico; informações sobre o local; informações dignas; transparência. \\
\hline
\end{tabular}

